\title{
CUSTOS DE PRODUÇ̃̃OA AGRíCOLA SOB CONDIÇÕES DE RISCO NO ESTADO DE SÃO PAULO
}

MARIA XENIA ISABEL CORVALÁN LATAPIA

Economista

Orientador. Prof. Dr. JOSE FERREIRA DE NORONHA

Dissertação apresentada à Escola Superior de Agricultura "Luiz de Queiroz", da Universidade de São Paulo, para obtenção do título de Mestre em Agronomia, ärea de concentração: Economia Agräria.

\footnotetext{
$P$ i $r$ a c i $c a b a$

Estado de São Paulo-Brasil

Maio/1988
} 
Corvalán Latapia, Maria Xenia Isabel

C832c Custos de produção agricola sob condições de risco no estado de são Paulo. Piracicaba, 1988.

$93 \mathrm{p}$.

Diss. (Mestre) - ESALQ

Bibliografia.

1. Custo de produção agrícola - São Paulo (Estado) I. Escola Superior de Agricultura Luiz de Queiroz, Piracicaba.

CDD 338.13 
CUSTOS DE PRODUÇÃO AGRICOLA SOB CONDIÇÕES DE RISCO

NO ESTADO DE SÃO PAULO

MARIA XENIA ISABEL CORVALĀN LATAPIA

Aprovada em: 16.05 .1988

Comissão Julgadora:

Prof. Dr. José Ferreira de Noronha

ESALQ/USP

Prof. Dr. Geraldo Sant'Ana de Camargo Barros

ESALQ/USP

Dr. Gabriel Luiz Seraphico Peixoto da Silva

IEA/SP

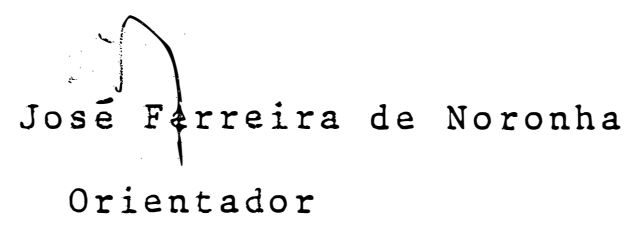


A memōria de meu pai René, pelo apoio e carinho assim como pelas lições de persé verança e honestidade.

A minha mãe, María pela fi bra e estimulos constantes.

A meu esposo e a meufilho, Jorge e Alvaro, pelo estimulo e compreensão. 
A Escola Superior de Agricultura "Luiz de Queiroz" e ao Departamento de Economia e Sociologia Rural que me possibilitaram a realização do curso de Pös-Graduação em Economia Agräria.

- A Coordenadoria de Aperfeiçoamento de Pessoal de Nivel Superior (CAPES) por propiciar bolsa de estudos, minorando as adversidades de ordem econömica enfrentadas durante o curso.

A Fundação de Amparo à Pesquisa do Estado de São Paulo (FAPESP) pelo financiamento concedido para a realização do presente trabalho.

Ao Prof. Dr. José Ferreira de Noronha, meu agradecimento especial pela constante e criteriosa orientação.

Ao Prof. Dr. Rodolfo Hoffmann cuja ajuda e estímulo foram de grande valia, assim como a importante con tribuição nesta dissertação desde o início, bem como o saber profissional, meu especial agradecimento.

Aos Drs. Gabriel Luiz Seraphico Peixoto da Silva, Geraldo Sant'Ana de Carmago Barros e Pedro Valentim Marques, pelas críticas e correções que contribuíram para o aprimoramento deste trabalho. 
i i i.

Sou grata a vārias pessoas pela amizade e pelos comentārios que foram de muita utilidade ao trabalho. Entre elas estão: Líster Manuel Corvalän Latapia, Sérgio Augusto Galvão Cézar, Joaquim Bento de Souza Ferreira FiIho e Antonio Celso Gemente.

A todos os colegas de curso, especialmente a Ikuyo Kiyuna, Maura Maria Demétrio Santiago, Geni Satiko Sato e Antonio Carlos Paula Neves da Rocha.

Agradeço especialmente ao Brasil, pela opor tunidade e apoio concedidos a uma estudante, pesquisadora chilena. 
LISTA DE FIGURAS $\ldots \ldots \ldots \ldots \ldots \ldots \ldots \ldots \ldots \ldots \ldots \ldots \ldots \ldots \ldots \ldots \ldots$

LISTA DE TABELAS $\ldots \ldots \ldots \ldots \ldots \ldots \ldots \ldots \ldots \ldots \ldots \ldots \ldots \ldots \ldots \ldots$

RESUMO $\ldots \ldots \ldots \ldots \ldots \ldots \ldots \ldots \ldots \ldots \ldots \ldots \ldots \ldots \ldots \ldots \ldots \ldots \ldots \ldots$

SUMMARY $\ldots \ldots \ldots \ldots \ldots \ldots \ldots \ldots \ldots \ldots \ldots \ldots \ldots \ldots \ldots \ldots \ldots \ldots \ldots \ldots \ldots$

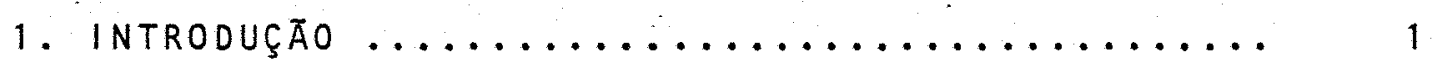

1.1 .0 problema.................. 3

1.2 . objetivos $\ldots \ldots \ldots \ldots \ldots \ldots \ldots \ldots \ldots \ldots \ldots \ldots \ldots \ldots \ldots$

1.3. organização da pesquisa $\ldots \ldots \ldots \ldots \ldots \ldots 6$

2. METODOLOGIA $\ldots \ldots \ldots \ldots \ldots \ldots \ldots \ldots \ldots \ldots \ldots \ldots \ldots$

2.1. Esquema do calculo do custo operacional efetivo, de acordo com o IEA ........... g

2.2. Anălise de sensibilidade .......... 12

2.3. Simulação Monte Carlo ............. 17

2.3.1. Processo de simulação ......... 17

2.3.2. Esperança do custo e desvio padrão para uma variàvel contínua com dis-

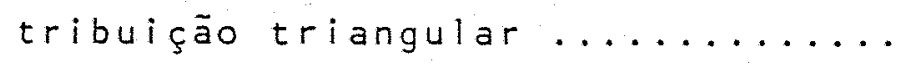

2.3.3. Método de transformação inversa ... 24

2.3.4. Pressuposições do modelo computacio

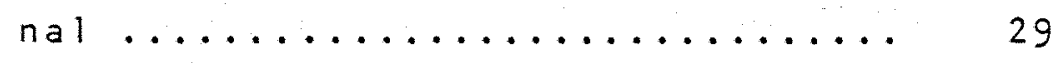

3. RESULTAdOS E DISCUSSÄO ................. 31

3.1 . Introdução ................... 31 
3.2. Funçöes de densidade de probabilidade das

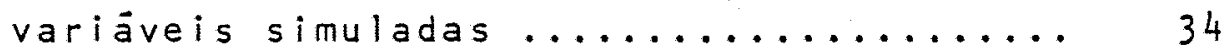

3.3. Simulação e anälise de riscos .......... 44

4. RESUMO CONCLUSOES E SUGESTOES ................ 50

REFERENCIAS BIBLIOGRAFICAS .................. 54

BIBLIOGRAFIA RECOMENDADA .................... 57

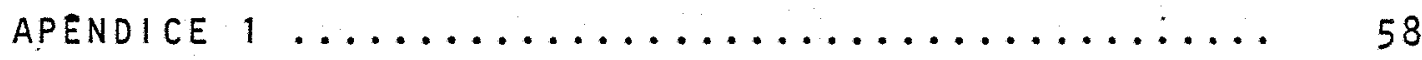

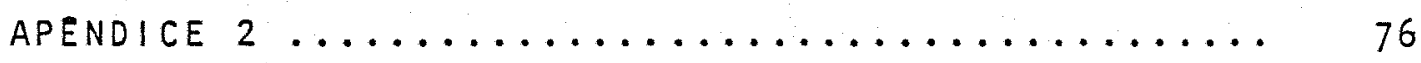




$$
\text { vi. }
$$

LISTA DE FIGURAS

pägina

1. Função densidade de probabilidade da variävel produtividade $\ldots \ldots \ldots \ldots \ldots \ldots \ldots \ldots \ldots \ldots \ldots \ldots \ldots \ldots \ldots$

2. Função de densidade de probabilidade triangular, da variàvel fertilizante/ha .......... 20

3. Distribuição de probabilidade uniforme ....... 21

4. Função densidade de probabilidade .......... 26

5. Função de distribuição acumulativa e determinação do valor simulado de uma variävel aleatória 28 
1. Esquema do cälculo do custo operacional efetivo

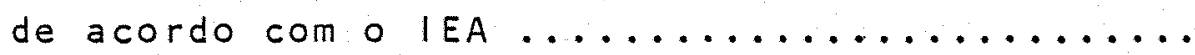

2. Variäveis selecionadas para simulação e as res-

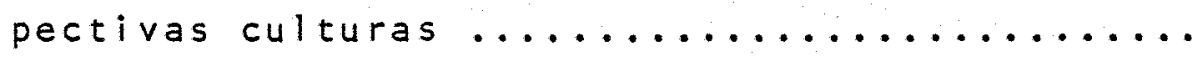

3. Valores mais prováveis das variäveis consideradas aleatörias, limites superiores e inferiores estabelecidos para a simulação, para as diver-

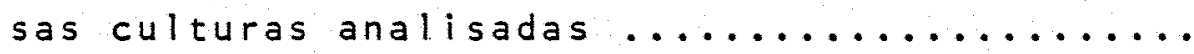

4. Esperança do custo e desvio padrão antes da simulaçäo, custo mëdio e desvio padrão estimado

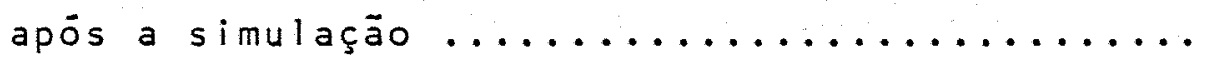


vi i i

CUSTOS DE PRODUÇÃO AGRTCOLA SOB CONDIÇOES DE RISCO

NO ESTADO DE SÃO PAULO

Autora: MARIA XENIA ISABEL CORVALAN LATAPIA Orientador: Prof. Dr. JOSE FERREIRA DE NORONHA

RESUMO

- presente trabalho analisa o comportamento de estimativas de custo de produção feitas pelo Instituto de Economia Agrícola da Secretaria de Agricultura de São Paulo sob condiçōes de risco.

A principal preocupação è verificar .o que acontece com os custos de produção quando se consideram al guns dos coeficiences tēcnicos de produçäo como variäveis aleatörias.

São consideradas nesta pesquisa as culturas de feijão, trigo, milho, arroz e cana-de-açücar. Usou-se a anälise de sensibilidade para identificar as variävis a serem simuladas. O processo consistiu em calcular a parti ticipação dos coeficientes previamente escolhidos no custo operacional efetivo.

$$
\text { Foram consideradas para a simulação as se- }
$$

guintes variàveis: 
a) $\mathrm{Na}$ cultura do feijão: carpa manual, coTheita manual, semente, adubo formulado (4-14-8), calcário, gradeaçāo, pulverização, herbicida, irrigação e fungi cida sistêmico.

b) $\mathrm{Na}$ cultura do trigo: semente, adubo formulado $(4-30-10)$.

c) Na cultura do milho: colheita manual, se mente, adubo formulado $(4-14-8)$, sulfato de amōnia em cobertura, gradeação e aração.

d) Na cultura do arroz: semente, adubo formulado $(4-14-8)$, araçäo, semente e sulfato de amōnio em co bertura:

e) Na cultura de cana-de-açūcar: corte, adu bo formulado (5-20-20), mudas, adubo formulado (19-5-19), a dubo formulado $(5-25-25)$, adubo formulado $(20-5-20)$ e carregamento.

Utilizou-se em seguida o método de simulação de Monte Carlo, gerando aleatoriamente novos valores para as variáveis selecionadas e obtendo a correspondente dist ibuição do custo de produção.

Na falta de melhores informações sobre as distribuiçōes de probabilidade decidiu-se usar a distribui ६̧ão triangular para todas as vinte variàveis. Considerou- se a moda igual ao valor dado pelo Instituto de Economia 
Agrícola e os limites minimos e mäximos foram pesquisados.

os resultados obtidos indicam que 13 das 17 planilhas de custo analisadas apresentaram probabilidades altas de ocorrerem custos superiores aos originalmente estimados pelo IEA.

Esse fato indica que, se estas estimativas forem usadas para estabelecer preços minimos, os agricultores correm um risco elevado de não terem cobertos seus custos. Indica, tambēm, a necessidade da introdução de aleatoriedade pelo menos em alguns dos elementos das matrizes de coeficientes de custos de produção. 
AGRICULTURAL PRODUCTION COSTS UNDER RISK CONDITIONS in the state of SÃo PAULO

Author: MARIA XENIA ISABEL CORVALAN LATAPIA Adviser: PROF. Dr. JOSE FERREIRA DE NORONHA

SUMMARY

The present study analized the behavior under risk condition of estimates of production costs made by the Instituto de Economia Agrícola from the Secretaria de Agricultura de São Paulo.

The main concern was to verify what happens to production cost when some of the technical production coefficients are considered as random variables.

Bean, wheat, corn, rice, and sugarcane crops were assessed in this search. Sensitivitys analysis was used in order to identify the variables to be simulated. The process consisted on calculating the coeficients participation to previously chosen coefficients over the effective operacional cost.

The following variables were selected for each simulation study:

a) Bean: hand weeding, manual cropping, seed, 
xi i .

(4-14-8) mixed fertilizer, limestone, harrowing, pulverization, herbicide, irrigation and systemic fungicide.

b) Wheat: seed, $(4-30-10)$ mixed fertilizer.

c) Corn: manual cropping, seed, (4-14-8) mixed fertilizer, ammonium sulphate in covering, harrowing and plowing.

d) Rice: seed, $(4-14-8)$ mixed fertilizer, plowing, seed and ammonium sulphate in covering.

e) Sugarcane crops: cutting, (15-20-20) mixed fertilizer, seedling (seedpieces), (19-5-19) mixed fertilizer, (15-25-25) mixed fertilizer, $(20-5-20) \mathrm{mixed}$ fertilizer and loading.

\section{Afterwards, the Monte Carlo simulation} method was applied generating randomly new values for the selected variables and acquiring the corresponding distribution of the production cost.

Due to the lack of further informations over probability distribution it was decided to use triangular distribution for all of them. The mode was considered to be equal to the value of coefficient used by the Instituto de Economia Agrícola. The minimum and maximum limits for each variable were researched, consulting specialists and the literature. 


$$
\text { xi i i . }
$$

The results indicated by simulation showed that 13 out of 17 analysed production costs presented high probabilities of being above the original estimates published by the IEA.

This result shows that if IEA estimates are used to establish minimum prices, the producers are highly endangered of not having their costs covered. It shows, also, the need for the introduction of randomization in at least some of the coefficients of the estimating matrices of production costs. 
1. INTRODUÇÃO

Durante anos o Instituto de Economia Agricola (IEA) vem efetuando estimativas de custo de produção de diversas explorações agrícolas no Estado de São Paulo e região Centro-sul do País. Em 1972, especialistas da instituição discutiram as metodologias de custo, propondo um procedimento alternativo: o chamado custo operacional. A justificativa apresentada para estimar e publicar apenas "os custos operacionais" e näo o custo total de produção foi que o"procedimento surgiu em virtude do comportamento observado dos produtores, os quais näo abandonavam a atividade nem reduziam a produção quando os custos superavam os preços de mercado"(MATSUNAGA et alii, 1976, p. 124).

Segundo estes mesmos autores, as informaçöes de custo de produção são aproveitadas para auxiliar na tomada de decisões de diversos agentes económicos. $\quad 0$ cälculo dos custos de produção agrícola é de vital importäncia tanto do ponto de vista do produtor como do governo. Para o produtor, as estimativas de custo permitem meIhorar sua gestão administrativa o planejamento de sua 
produção, enquanto que para o governo fornecem subsídios às formulaçōes de polfticas agrícolas e diretrizes para a tomada de decisöes.

Acrescentam ainda que "o principal objetivo do custo operacional é de ser um indicador, o mais preciso possível, das decisões de produçãoll (p. 137).

Essas estimativas de custo operacional são feitas com base nas matrizes de coeficientes tëcnicos de utilização de fatores de produção. Os coeficientes são calculados com base em dados levantados junto aos produtores, periodicamente revisto, em alguns casos, substituidos, conforme é apontado em diversos estudos divulgados, tais como: ARRUDA, 1985; PIRES, 1979; MELLO, 1978 e MELLO et alii, 1985 .

Os autores mencionados determinam, em trabalhos distintos, os coeficientes técnicos de operaçöes e exigencias físicas de insumos para diversas culturas no Estado de São Paulo. De acordo com aqueles estudos, o item que maior participação tem no custo das diversas culturas é a quantidade de dias de serviço de mão-de-obra comum, variando somente a intensidade de participação desse item nas diversas operaçöes.

Do estudo de MELLo et alii (1985) depreende-se que, para as culturas arroz de sequeiro com tração 
motomecanizada (TM), feijão com tração motomecanizada animal (TMA), feijão com tração animal (TA), milho com TMA e mil ho com TM, as maiores participações nas estimativas do custo operacional foram mão-de-obra comum, adubo e corretivo. Os percentuais relativos à adubo e corretivos no caso da cultura arroz de sequeiro (TM), feijão (TMA), mi1ho (TMA) e milho (TM) são: $23 \%, 21 \%, 21 \%$ e $25 \%$, respectivamente. Um indice elevado de participação de mão-de-obra no custo operacional total ocorre na cultura feijão (TA), com $27 \%$.

\subsection{O problema}

Estudos têm sido feitos com o sentido de discutir as metodologias empregadas, assim como revelar importancia e finalidade da determinação dos custos de produção na agricultura. Mas pouca importância tem sido dada às fontes de riscos na produção agrícola. Alēm dos riscos climäticos, existem aqueles ligados às características regionais, que, de uma ou outra forma, afetam os custos de produção, atravēs dos coeficientes tëcnicos e insumos utilizados na sua composição. O rendimento por hectare, por exemplo, que afeta o custo operacional mëdio, varia bastante com a fertilidade do solo, as condições climáticas, a técnica utilizada, etc. A quantidade de adubo por hectare 
deve variar com a fertilidade do solo. A quantidade de pesticidas utilizada ē funçäo da incidencia de pragas e doenças, que por sua vez, depende de condiçöes climäticas.

o rendimento agrícola do arroz no Estado de São Paulo apresenta oscilaçōes marcantes nas produçōes anuais. o arroz de sequeiro e arroz obtido por irrigação mostram produtividades diferentes. "A produção por hectare do arroz de sequeiro $\vec{e}$ bem inferior àquela obtida pelo irrigado. Uma das causas destas discrepancias estä vinculada a fatores climäticos, jä que o arroz de sequeiro estä na dependēncia de uma boa distribuição de chuvas.

o fato de o arroz de sequeiro apresentar uma dependência muito grande de fatores climäticos, refletindo-se isto em oscilações marcantes nas produções anuais, mostra a presença de aleatoriedade no rendimento.

o custo operacional è calculado pressupondo que os coeficientes tëcnicos ocorrem em condiçöes de certeza. No entanto, um exame das operaçöes e insumos empregados no cälculo de custo de produção durante o processo produtivo, e o reconhecimento da existência de uma grande vulnerabilidade desses em relação a fatores não controläveis, como ataque de doenças, incidencia de pragas e molëstias presentes em alguns casos, mostra que dificilmente verifica-se a condição de certeza. 
Portanto é legítimo perguntar qual serä o impacto dessas variaçöes aleatörias nos coeficientes tëcnicos sobre os valores estimados dos custos de produção. ou seja, como o custo operacional responde às flutuaçöes nos coeficientes tëcnicos usados originalmente. Esta é a essência da anälise de riscos. "As condiçōes de risco, em geral, aparecem quando existe a probabilidade de um resultado diferente daquele que era esperado" (CONTADOR, 1981, p. 191).

Constitui uma interessante tarefa considerar variaçōes aleatörias nos coeficientes técnicos e verificar sua incidencia sobre o custo de produçäo. Isto serviria como indicador, com alguma margem de segurança, para auxiliar na tomada de decisão dos produtores, dar maior certeza para impiementação de politicas agrícolas e verificar a qualidade do procedimento utilizado pelo IEA.

A solução para o tratamento do risco foi encontrada na técnica de simulação do tipo estocāstica, conhecida tambēm como Mētodo de Simulação de Monte carlo. Este método obtém como resultado não um valor do custo de produção efetivo, mas uma distribuição de freqüencias do mesmo. 


\subsection{Objetivos}

o objetivo geral do estudo è de proceder a uma analise do comportamento das estimativas dos custos de produções agrícolas sob condiçōes de incerteza.

Os objetivos especificos podem ser assim a-

linhados:

a) obter a distribuição de freqüencia do custo operacional admitindo que alguns coeficientes tëcnicos são variáveis aleatórias e, com base nessa distribuição, discutir a qualidade das estimativas de custo operacional do IEA;

b) discutir as implicaçōes präticas decorrentes do atual sistema de cálculos de custos sobre a poliftica de preços mínimos.

1.3. Organização da pesquisa

No capitulo 2 é apresentada a metodologia utilizada neste trabalho, sendo assim subdividida:

a) esquema de cálculo do custo operacional efetivo de acordo com o IEA;

b) anälise de sensibilidade;

c) simulação Monte Carlo. 
o capitulo 3 trata dos resultados e discussäo, subdividindo-o nos seguintes itens:

a) introduçäo;

b) funções de densidade de probabilidade das variäveis simuladas;

c) simulação e anālise de riscos.

o ültimo capitulo inclui o resumo, as conclusões e algumas sugestões. 
8.

2. METODOLOGIA

Nesta seção serä apresentado, em primeiro lugar, o esquema de cälculo do custo de produção do IEA. E a partir desse esquema que será feita a anälise de riscos.

A seguir discutir-se-à a anälise de sensibilidade, utilizada neste trabalho para a seleção das variäveis que posteriormente serão simuladas. Finalmente, será explicado o funcionamento do- processo de simulação usando a técnica de Monte Carlo, que é a metodologia bäsica empregada nesta pesquisa.

A utilização de simulação permitirä testar os efeitos de variações nos coeficientes técnicos sobre os custos, atribuindo-se a cada um dos coeficientes técnicos uma certa distribuição de probabilidade.

Aplicações desse modelo na anälise de projetos agrícolas podem ser encontradas em NORONHA (1981, 1984), AZEVEDO FILHO E ROSA BELO (1984), NEVES (1984) entre outros. 
2.1. Esquema de cálculo do custo operacional efetivo, de acordo com o IEA

o custo operacional efetivo (COE) compöe-se de todos os itens de custo considerados variäveis ou despesas diretas, representados pelo dispêndio, em dinheiro, com mão-de-obra, sementes, fertilizantes, defensivos, combustivel, reparos, alimentação, vacina e medicamentos. Adicionando-se aos itens acima depreciação de mäquinas (que e uma parcela dos custos fixos ou indiretos) e juros bancärios, o valor encontrado recebe o nome de custo operacional efetivo total.

Os coeficientes técnicos por operação e as exigências físicas de insumos, por hectare, são determinados através do cälculo de uma média da amostra levantada.

A estrutura do custo operacional efetivo apresentado pelo IEA consta de duas partes. A primeira parte mostra as operaçōes executadas e os fatores de produçāo utilizados em cada uma delas. Nesta parte a intersecção da coluna com a linha reflete o coeficiente técnico de utilização do fator expresso em tempo de serviço por hectare (dias-homem ou dias-mäquina).

A soma de tais coeficientes oferece o total de tempo de serviço, especificado por fator. Multiplicando 
cada um pelo custo diärio e somando, obtém-se o total de despesas com operações.

A segunda parte contém a quantidade de insumos consumidos por hectare e seus respectivos preços. Em conjunto, estas duas partes formam o custo operacional efetivo.

A forma de cálculo do custo operacional efetivo dessa estrutura estä descrita na tabela 1. Os itens podem ser resumidos de acordo com a seguinte notação:

$a_{i j}=$ nümero de dias de serviço do fator $\mathbf{j}$ necessärios à realização da operação $\mathbb{I}(i=1, \ldots, 1 ; j=1, \ldots, J)$ 1 = nümero de operaçōes $J=$ nümero de fatores

$C D_{j}=$ custo diärio do serviço do fator $L$

$q_{h}=$ quantidade do insumo $\underline{h}$

$P_{h}=$ preço do insumo $\underline{h}$

$T D_{j}=$ total de dias de serviço do fator de produçäo $\mathcal{L}$, por hectare, em todas as operaçōes

$D O_{j}=$ despesa total com as operaçōes realizadas com o fator de produção $\underline{j}$

$O D$ = outras despesas

$$
\begin{aligned}
& \text { Verifica-se que } \\
& T D_{j}=\sum_{i} a_{i j} \text { e que } D O_{j}=C D_{j} T D_{j}=C D_{j} \sum_{i} a_{j}
\end{aligned}
$$


Então o subtotal relativo às despesas com 으 perações e outras despesas ë

$$
S T_{1}=\sum D O j+O D \text { Ou } S T_{1}=\sum_{j} C D D_{j} \sum_{i} a_{i j}+O D .
$$

A despesa total com materiais è dada por

$D M=\sum_{h} p_{h} q_{h}$

Conclui-se, entāo, que o Custo operacional

Efetivo (COE) è dado por

$$
C O E=S T_{1}+D M \quad O U \quad C O E=\sum_{j} D O_{j}+D M+O D
$$

ou, a inda,

$$
C O E=\sum_{j} C D_{j} \sum_{i} a_{j}+\sum_{h} p_{h} q_{h}+O D
$$

Tabela 1. Esquema do cälculo do custo operacional efetivo de acordo com o IEA

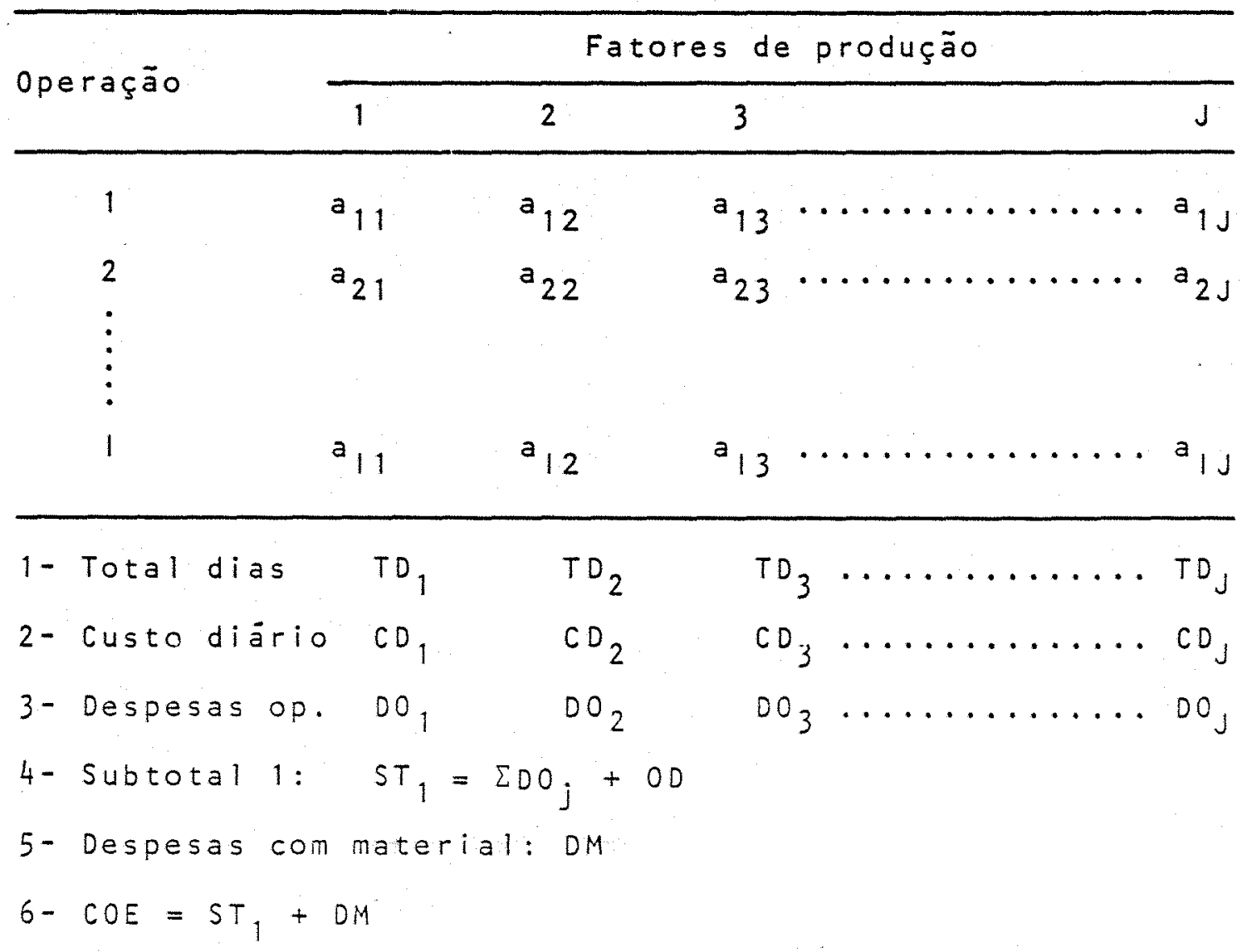


2.2. Anälise de sensibilidade

A tëcnica mais simples e mais empregada na prätica para avaliar risco è a anălise de sensibilidade.

Segundo CONTADOR (1981, p. 188), fazer uma anälise de sensibilidade è "variar numa certa faixa as estimativas daqueles parâmetros mais sujeitos a incerteza, e observar o que acontece com o resultado final". Procedendo-se desse modo com os diversos parámetros será possivel escolher aqueles mais importantes em termos de influencia nos resultados da anälise (WOILER \& MATHIAS, 1986).

Similarmente, para SOLOMON (1970), a anälise de sensibilidade consiste na determinação do efeito causado nos resultados por valores de parämetros diferentes dos presumidos.

Neste estudo, a anälise consistirä em calcular a participação de alguns elementos do custo, consideradosi os mais significativos, na estimativa de custo operacional efetivo dos produtos analisados, de acordo com o seguinte procedimento.

o impacto sobre o custo operacional efetivo pode ser analisado atravēs de variações nos seguintes elementos:

a) quantidade de insumo empregado $\left(q_{h}\right)$ 
13.

b) preço do insumo utilizado $\left(p_{h}\right)$

c) custo do dia de serviço dos fatores $\left(C D_{j}\right)$

d) tempo de realização das operaçōes $\left(a_{i j}\right)$

a) Se a quantidade do insumo k cresce $1000 \%$, a nova quantidade è

$$
q_{k}=q_{k}(1+\theta)
$$

O novo custo operacional efetivo (COE') è:

$$
\operatorname{COE}=\operatorname{COE}+\theta p_{k} q_{k} \text {, }
$$

onde $p_{k}$ é o preço do insumo $k$.

Segue-se que

$$
\triangle C O E=C O E^{\prime}-C O E=\theta p_{k} q_{k}
$$

Dividindo todos os termos de (1) por COE, ob tem-se

$$
\frac{\Delta C O E}{C O E}=\theta \frac{P_{k} q_{k}}{C O E}
$$

$$
\text { Mas } \theta=\frac{\Delta q_{k}}{q_{k}}
$$

Então 


$$
\frac{\frac{\triangle C O E}{C O E}}{\frac{\Delta q_{k}}{q_{k}}}=\frac{p_{k} q_{k}}{C O E}
$$

Note-se que o primeiro termo da relação. ( $\stackrel{3}{2})$ è a relação entre a variaçäo percentual do custo $\left(\frac{\triangle C O E}{C O E}\right)$ e a variação percentual na quantidade do insumo $k$.

Então a expressão (3) mostra que a elasti cidade do custo em relação a $q_{k}$ è igual à participação do $k$-ësimo insumo no custo operacional efetivo.

b) 0 preço do insumo $k$ cresce $1000 \%$. Entäo o novo preço é

$$
p_{k}^{\prime}=p_{k}(1+\theta)
$$

Analogamente a (2), obtem-se

$$
\begin{aligned}
& \frac{\triangle C O E}{C O E}=\theta \frac{P_{k} q_{k}}{C O E}, \\
& \text { onde } \theta=\frac{\Delta p_{k}}{p_{k}} \cdot \text { segue-se que } \\
& \frac{\frac{\Delta C O E}{C O E}}{\frac{\Delta p_{k}}{p_{k}}}=\frac{p_{k} q_{k}}{C O E}
\end{aligned}
$$


Essa relação mostra que a elasticidade do custo em relação ao preço $p_{k}$ è, tambēm, igual à participaf̧ão do k-ësimo insumo no custo.

c) O custo do dia de serviço do fator m cresce $1000 \%$. Então o novo valor desse custo é

$$
\begin{aligned}
& C D_{m}^{\prime}=C D_{m}(1+\theta) \\
& \text { o novo valor do Custo Operacional Efetivo é } \\
& C O E^{\prime}=C O E+\theta C D_{m} \sum_{i} a_{i m}
\end{aligned}
$$$$
\text { Segue-se que }
$$$$
\frac{\Delta C O E}{C O E}=\theta \frac{C D_{m} \sum_{i} i m}{C O E}
$$

com

$$
\theta=\frac{\Delta C D_{m}}{C D_{m}}
$$

Lembrando que o total de dias de serviço do fator $m \bar{e} T D_{m}=\sum_{i} a_{i m}$, conclui-se que

$$
\frac{\frac{\Delta C O E}{C O E}}{\frac{\Delta C D_{m}}{C D_{m}}}=\frac{C D_{m} \sum_{i} a_{i m}}{C O E}=\frac{C D_{m}{ }^{T} D_{m}}{C O E}
$$


16.

Essa relação mostra que a elasticidade do custo em relação ao custo diärio de serviço do fator m è igual à participação desse fator no COE.

d) O tempo de realização da operação n cresce $1000 \%$, de maneira que os novos tempos de uso dos fatores para realizar essa operação são

$$
\begin{gathered}
a_{n j}^{\prime}=a_{n j}(1+\theta) \text { para todo } j \\
\text { Então } \\
\text { COE' }=\text { COE }+\underset{j}{\operatorname{COC}} D_{j} a_{n j} .
\end{gathered}
$$

Segue-se que

$$
\frac{\Delta C O E}{C O E}=\theta \frac{\sum_{j}^{\sum C D} a_{n j}}{C O E}
$$

onde, para todo $j$,

$$
\theta=\frac{\Delta a_{n j}}{a_{n j}}
$$

Conclui-se que

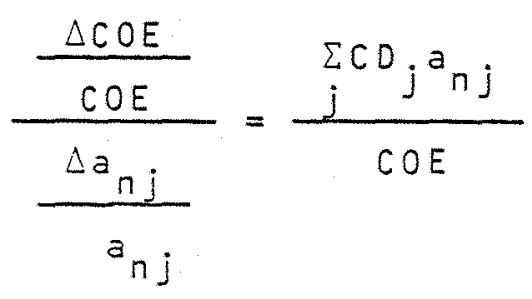


17.

Verifica-se, portanto, que a elasticidade do COE em relação ao tempo de realização da operação n é igual à participação dessa operação no custo.

Identificadas as variäveis mais importantes usa-se então o mëtodo de simulaçäo de Monte Carlo, bastante utilizado como técnica de anālise de riscos em projetos, para avaliar o risco de se considerar o custo operacional mëdio como indicador de política ou tomada de decisão.

\subsection{Simulação Monte Carlo}

\subsubsection{Processo de simulação}

Selecionadas as variäveis a serem simuladas, seguindo recomendações de NAYLOR et alii (1971), mencionado por SA (1985), é escolhida uma distribuição téörica adequada para explicar o comportamento dessas variäveis. De acordo com NORONHA (1981) essa distribuição é construída com base na experiencia do empresärio elou especialistas na cultura, usando estimativas subjetivas de probabilidade. 
De acordo com REUTLINGER (1979), a utilizaçäo de probabilidades subjetivas ${ }^{2}$ melhora o nivel das informações disponíveis e nem sempre é possível determinar objetivamente distribuição da variāvel aleatória.

Segundo CORVALAN (1987) "o termo probabilidade subjetiva refere-se à obtenção de medidas de probabilidades a partir da decisão que é inteiramente da responsabilidade de cada individuo, a qual é influenciada por fatores psicológicos representados pelos juizos subjetivos das probabilidades de ocorrencia dos eventos" (p. 17).

Em alguns casos será possível estudar a distribuição do coeficiente tēcnico no passado e, dessa maneira, obter uma estimativa de sua distribuição. Por exemplo, a partir de searies históricas do valor do rendimento por hectare de uma cultura em vāíias regióes do Estado, será possivel obter um histograma que mostre a variabilidade desse coeficiente.

Para isso os dados observados nas séries histōricas são organizados em uma tabela de distribuição de freqüencias. Inicialmente, são fixados os intervalos de classe; em seguida os dados são classificados nesses in-

1 Os conceitos teöricos destes termos podem ser encontrados em diversos livros de estatística bäsica. Por exemplo LEME (1972), SPIEGEL (1978). 
tervalos, são obtidas freqüencias relativas, e finalmente è construida a função de densidade (figura 1 ).

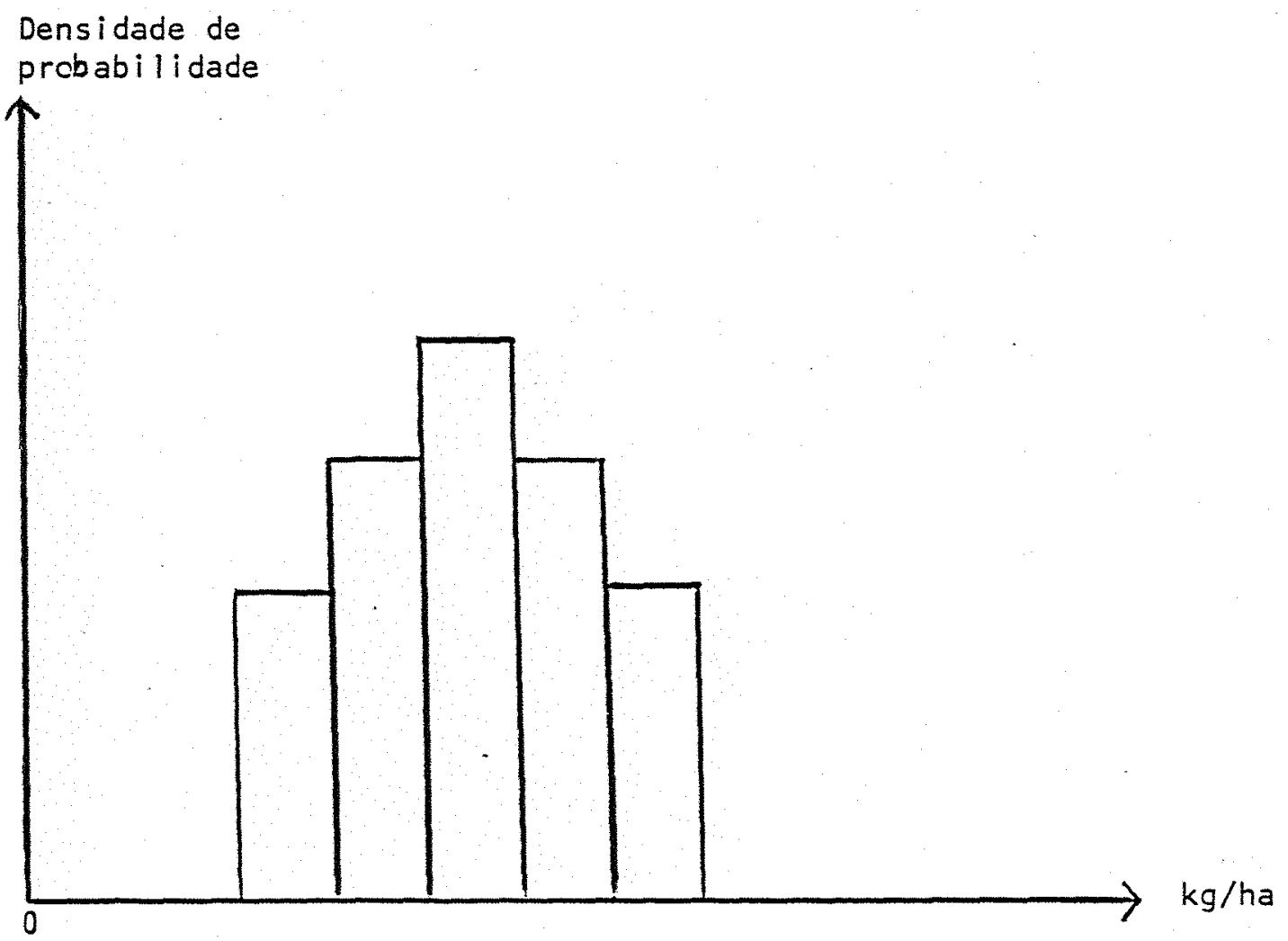

Figura 1. Função de densidade de probabilidade da variàvel produtividade.

Em outros casos poderä ser utilizada uma distribuição mais simples. Consideremos, por exemplo, a quantidade de adubo por hectare. Agrônomos com experiência na cultura poderão informar quais as doses geralmente utilizadas. Admitindo que a distribuição desses coeficientes técnicos seja triangular, basta conhecer a dose minima, a dose modal e a dose mäxima para que se possa estabelecer a distribuição da quantidade de adubo utilizada 
por hectare. Esta distribuição è bastante utillizada quando não se tem muitas informações sobre as variäveis.

A representação gräfica è mostrada na figu-

ra 2 , onde:

m è a dose modal ou valor mais provävel da variável;

a é a dose mínima ou valor mínimo assumido pela variável; b è a dose mäxima ou valor mäximo assumido pela variável. Densidade de probabilidade

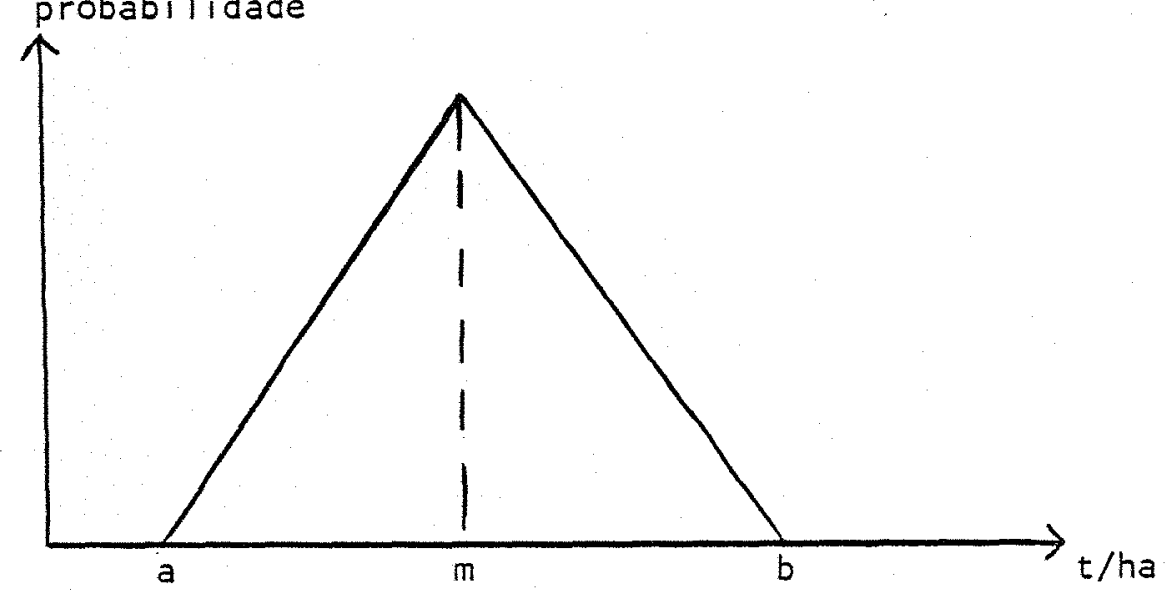

Figura 2. Função de densidade de probabilidade triangular da variāvel fertilizante/ha.

Se acaso a distribuição for uniforme entre dois valores, obter-se-ä a figura 3 . 
Densidade de probabilidade

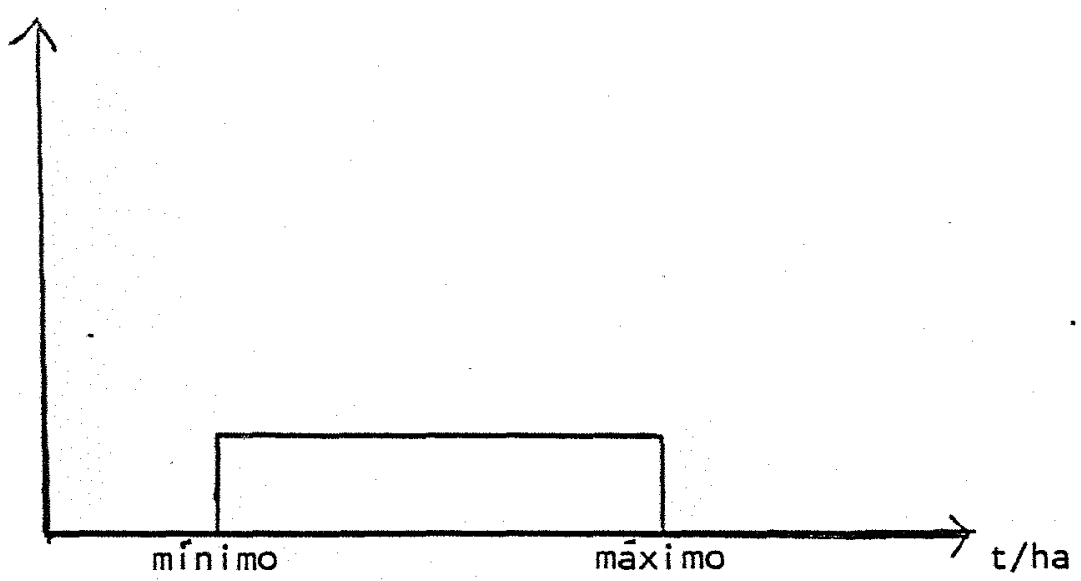

Figura 3. Distribuição de probabilidade uniforme.

Identificadas as distribuiçöes de probabilidade, escolhe-se, dentro de cada uma destas, um valor para cada uma das variävis selecionadas. Estes valores, selecionados ao acaso, vão substituir os valores originais, o que permitirà estimar um novo custo por unidade de produto.

Este processo é feito simultaneamente em todas as variäveis simuladas, e repetido certo nümero de vezes de modo que permita estabelecer uma distribuição de freqüencias do custo para cada cultura em estudo. Ou seja, determina-se não sö o custo mëdio, mas tambëm a variância dessa variävel e pode-se estimar a proporção de agricultores que terão, em um ano qualquer, custo unitärio acima ou abaixo de certo valor. 
Isto permitirá que se analise o risco assumido quando se estabelece uma política de preços com base em uma ünica estimativa do custo mēdio. Permite, tambēm, uma avaliação da qualidade das estimativas de custo de produção baseadas em valores médios dos coeficientes tëcnicos.

2.3.2. Esperança do custo e desvio padräo para uma variävel continua com distribuição triangular

Na falta de melhores informações sobre as distribuições de probabilidades, decidiu-se usar a distribuição triangular para todas elas.

Esta distribuição é definida pelo nível mais provável ou moda (m), por um nivel minimo (a) e um nível mäximo (b) (figura 2).

Neste estudo serão calculadas a esperança do custo e o desvio padrão antes de efetuada a simulaçäo, assim como o custo médio e o desvio padrão estimado depois de efetuada a simulação.

A mèdia e a variância de uma variävel contínua com função de densidade triangular são dadas pelas se guintes expressões: 


$$
\begin{aligned}
& E(x)=\frac{a+m+b}{3} \quad e \\
& \sigma^{2}=\frac{1}{18}\left(a^{2}+m^{2}+b^{2}-a m-a b-b m\right)
\end{aligned}
$$

Para efeito da simulação o custo operacional efetivo estará composto de uma parcela de custo não su jeita a variação (CF) e de parcelas sujeitas a variação.

E dix̌̉er que a equação do COE estarà dada

por

$$
\operatorname{COE}=C F+c_{1} x_{1}+c_{2} x_{2}+\cdots+c_{i} x_{i}
$$

onde:

$x_{i}$ è a quantidade de insumo empregado, preço do insumo utilizado, custo do dia de serviço dos fatores ou tempo de realização das operaçōes, dependendo de quais dessas variäveis queiram se simular

$c_{i}$ deverä ser o parâmetro correspondente à variävel simulada.

Logo, no cälculo probabilístico a esperança do custo obedece à seguinte förmula

$$
E(C O E)=C F+\sum C_{i} E\left(x_{i}\right)
$$

ou

$$
E(C O E)=C F+\Sigma c_{i} \cdot \frac{a_{i}+b_{i}+m_{i}}{3}
$$


Uma vez que as variäveis säo simuladas de maneira independente, a variância do coe esta dada pela se guinte expressão:

$$
V(C O E)=\Sigma c_{i}^{2} V\left(x_{i}\right)
$$

ou

$V(\operatorname{COE})=\Sigma \frac{c_{i}^{2}}{18}\left(a_{i}^{2}+m_{i}^{2}+b_{i}^{2}-a_{i} m_{i}-a_{i} b_{i}-b_{i} m_{i}\right)$.

\subsubsection{Mētodo de transformação inversa}

E interessante detalhar a maneira como é obtido o valor simulado de uma variàvel aleatöria.

Selecionadas as variáveis mais relevantes consideradas aleatörias para serem simuladas, escolhe-se a a distribuição de probabilidades adequada para representar - comportamento de cada variàvel, sendo comum a adoção de uma distribuição triangular, uniforme, normal ou de uma distribuição representada por um histograma, dependendo das informaçöes disponíveis. 
Num processo estocástico que envolve variäveis aleatörias contínuas, a distribuição è caracterizada pela função de densidade de probabilidade.

Uma função $f(x)$ que satisfaz as propriedades: $f(x) \geq 0$ e $\int_{-\infty}^{+\infty} f(x) d x=1$ é automaticamente uma função de densidade, e dela se podem deduzir as probabilidades desejadas, mediante a utilização da förmula $P(a<x<b)=\int_{a}^{b} f(x) d x(S P \mid E G E L, 1978)$. A função de distribuição $F(x)$ representa a probabilidade da variável aleatöria $x$ assumir um valor menor ou igual a $x$, obedecendo à seguinte förmula, no caso de envolver uma variävel contínua:

$$
F(x)=P(x \leqq x)=\int_{\infty}^{x} f(u) d u,
$$

onde $f(u)$ representa o valor da função densidade de probabilidade da variável aleatöria quando $x=u$.

$$
\text { A derivada da função de distribuição è a }
$$

função de densidade. Matematicamente está expressa da seguinte maneira

$$
f(x)=\frac{d F(x)}{d x}
$$

$$
\text { Geometricamente, } f(x) \text { "ë a inclinação }
$$

da tangente à curva da função de distribuição $F(x)$ no ponto 
$x$; e $F(x)$ è a ärea sob a curva de densidade de probabilidade à esquerda do ponto x (LEME, 1972, p. 96) (figura 4).

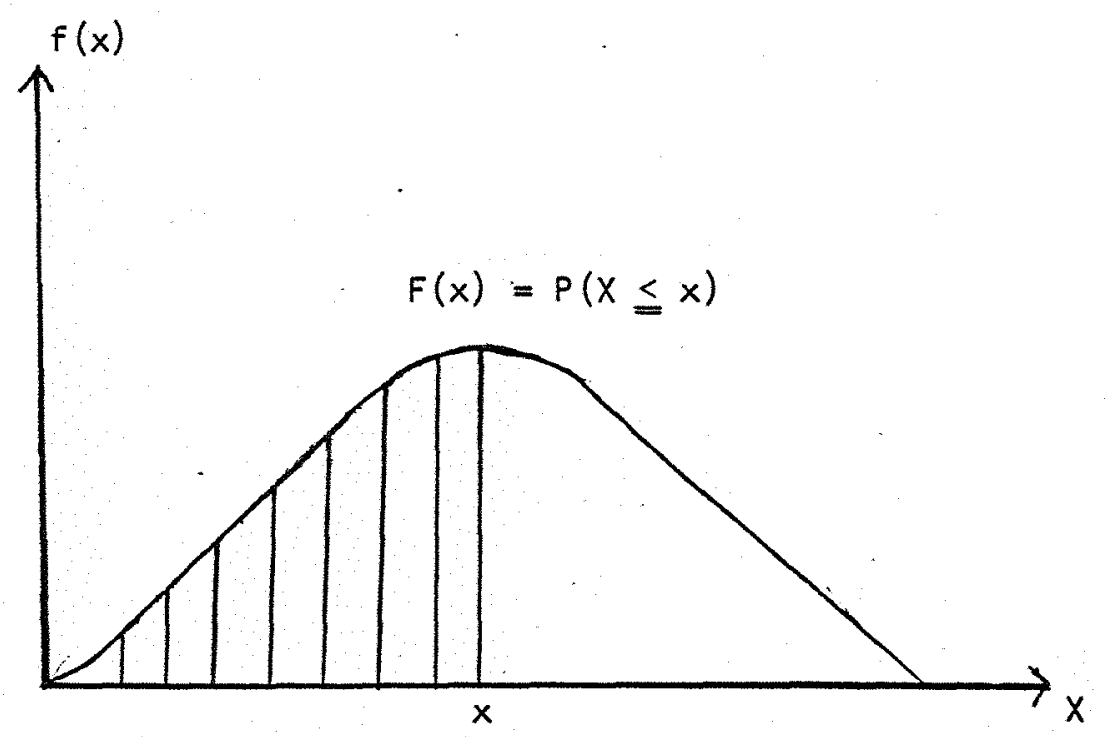

Figura 4. Função densidade de probabilidade.

Uma vez individualizada a distribuição de probabilidade de cada uma das variàveis indicadas pela anălise de sensibilidade, a próxima etapa do processo de simulação é a seleção ao acaso de um valor para cada uma das variăveis dentro das distribuições pré-estabelecidas. Para associar um nümero aleatörio à distribuição de probabilidade de cada variável são utilizados nümeros gerados a partir de uma distribuição uniforme no intervalo fechado $(0,1) .^{1}$ Um dos métodos básicos para a geração de valores através de distribuições de probabilidade é o Mëtodo de Transformação Inversa.

1 Para uma descrição das técnicas de geração de nümeros aleatōrios ver NAYLOR (1971). 
A curva mostrada na figura 5 è a função de distribuição acumulativa $F(x)$. Uma vez definida esta função em todo o intervalo 0 a 1 pode-se gerar nümeros aleätörios $(u)$, uniformemente distribuido e fazer $F(x)=u$. Segue-se por isso que, graficamente, pode-se casar cada nümero aleatörio com sua contrapartida na escala vertical (probabilidade acumulada de ocorrencia). Desse ponto prossegue-se horizontalmente a direita atē atingir a curva acumulativa. Descendo no eixo horizontal é possivel achar - valor de $x$. Cada nümero aleatörio u determina univocamente um valor de $x$. Este valor de $x$ será um novo valor do coeficiente tëcnico. Obviamente este processo pode ser repetido tantas vezes quantas forem necessärias gerando de cada vez um valor para $x$. Matematicamente:

"para qualquer valor particular de u, por exemplo, que tiver-se gerado, é possivel achar o valor de $x$, nesse caso $\left(x_{0}\right)$ correspondente a $u_{0}$, pela função inversa de $F$, se a mesma for conhecida.

Isto è:

$$
\begin{gathered}
x_{0}=F^{-1}\left(u_{0}\right) \\
F^{-1}(u) \text { è a transformação inversa de } u \text { no in- }
\end{gathered}
$$
tervalo unitärio do domínio de $x^{\prime \prime}$ (NAYLOR, 1971, p. 88). 


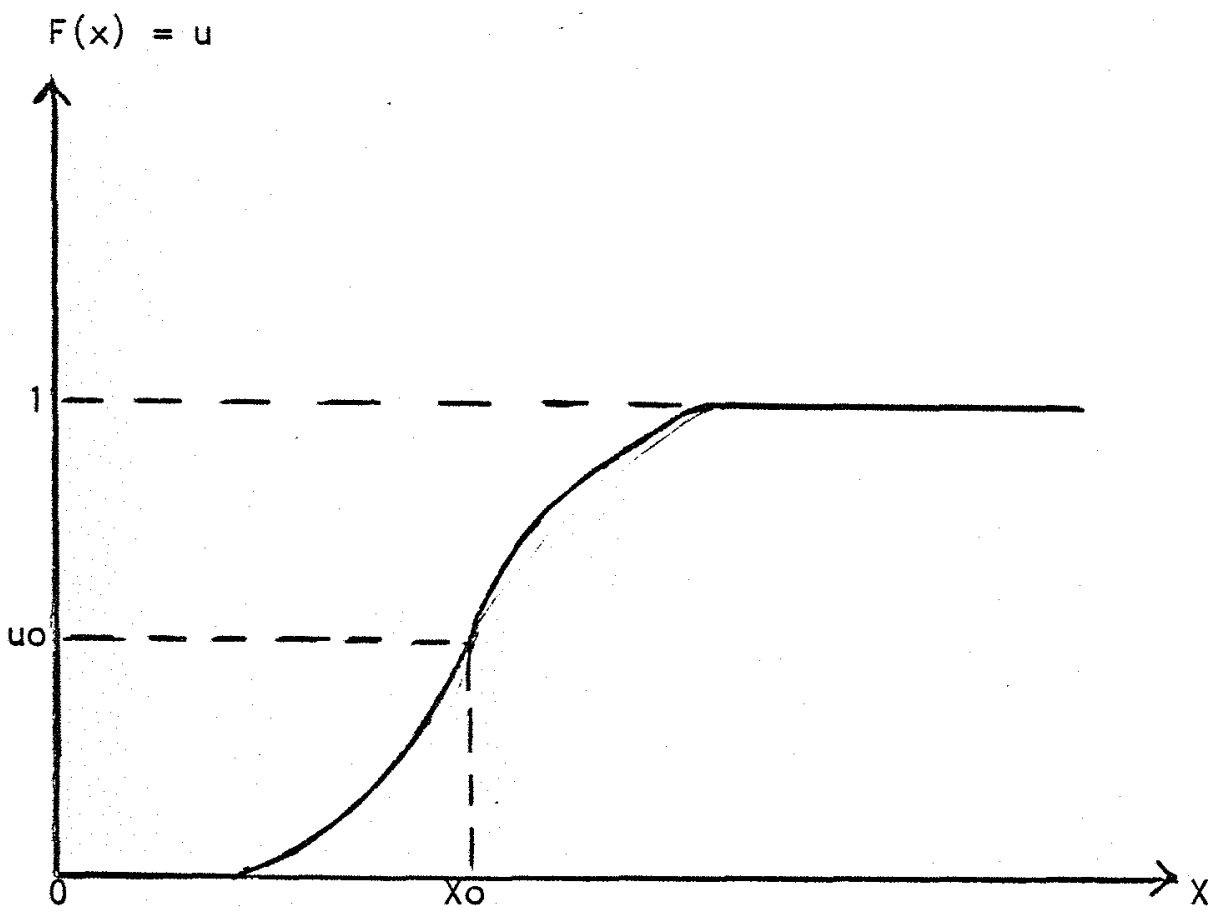

Figura 5. Função de distribuição acumulativa e determinação do valor simulado de uma variàvel aleatória. o processo de simulação compreende a geração simultánea de valores ao acaso para as variäveis selecionadas.

os valores simulados substituem os coeficientes técnicos originais na planilha de custos obtendo-se um "novo" custo operacional efetivo para cada conjunto de valores simulados.

Com a finalidade de obter a distribuição de freqüencia do custo por unidade (custo mëdio) repete-se o processo um nümero suficiente $(10.000$ nesta pesquisa) para cada cultura. A freqüencia relativa dos custos por unida- 
de serä tomada como medida de probabilidade de que os custos indicados nos intervalos venham a ocorrer, sob as condições de incerteza consideradas.

\subsubsection{Pressuposiçōes do modelo computacional}

Um dos principais requisitos de um processo de amostragem aleatöria è a independência estatística. Matematicamente, se $X$ e $Y$ são variàvis aleatörias contínuas, diz-se que säo variäveis aleatörias independentes se os eventos $X \leqq X$ e $Y \leqq y$ são eventos independentes para todo $x$ e todo $y$.

E pode-se escrever:

$P(x \leqq x, \quad Y \leqq y)=P(X \leqq X) . \quad P(Y \leqq y)$ ou equivalente: $F(x, y)=F_{1}(x)$. $F_{2}(y)$, onde $F_{1}(x)$ e $F_{2}(y)$ são as funções de distribuição (marginal) de $X$ e $Y$, respectivamente. Reciprocamente, se para todo $x$ e todo $y$, a função de probabilidade conjunta $F(x, y)$ pode expressar-se como o produto de uma função só de $x$ e uma função só de y las quais são então as funções de probabilidade marginal de $X$ e $Y$, respectivamente) $X$ e $Y$ são independentes (SPIEGEL, 1978).

Esta pressuposição ē normalmente usada em estudos de simulação pelo mëtodo de Monte Carlo. Admite- se entretanto, que existe dependencia entre certas variá- 
veis e sugere-se que, em outras pesquisas, este aspecto seja considerado. Este processo de simulação foi feito em um microcomputador. ${ }^{1}$

1 o programa de cälculo foi escrito em linguagem BASIC pelo Prof. Rodolfo Hoffmann, do DESR/ESALQ/USP, originalmente para esta pesquisa. Para maiores detalhes, ver HOFFMANN et azii (1937). 
31.

\section{RESULTADOS E DISCUSSÃO}

\subsection{Introdução}

Os coeficientes técnicos que compõem a estrutura do custo de produção foram obtidos da revista "Informações Econômicas" publicada pelo Instituto de Economia Agrícola de São Paulo, no período compreendido entre 1981 e 1986.

Devido ao fato de os coeficientes técnicos não terem mostrado variações significativas atravēs dos anos nas diversas culturas, optou-se por analisar somente o ano de 1986.

As culturas objeto de estudo foram: trigo, feijão, arroz, milho e cana-de-açücar (para diversos estägios de produção).

$$
\text { Para fins de anàlise, as culturas, com seus }
$$

diversos sistemas de produçäo ${ }^{1}$ foram codificadas como se

1 Sistema de produção refere-se a diversas trações utilizadas basicamente, alëm de pequenas diferenças nos niveis de insumos utilizados. 
mostra a seguir:

cultura A: arroz irrigado TM, lha, produção $55 \mathrm{sc} ., 60 \mathrm{~kg}$, DIRA Vale, Estado de Säo Paulo, safra $86 / 87$

cultura B: arroz sequeiro. TM, $1 \mathrm{ha}$, produção $27 \mathrm{sc}, 60 \mathrm{~kg}$, DIRA Ribeirão Preto, Estado de São Paulo, safra $86 / 87$

cultura C: cana-de-açücar TM, 1ha, produção $95 t$, plantio, DIRA Campinas, Estado de Säo Paulo, safra $86 / 87$ cultura D: cana-de-açúcar TM, lha, produção $62 t, 2$ ? corte, DIRA Campinas, Estado de São Paulo, safra $86 / 87$ cultura E: cana-de-açücar TM, 1ha, produção $52 t, 3$ : corte, DIRA Campinas, Estado de São Paulo, safra $86 / 87$ cultura F: cana-de-açúcar TM, lha, produção $100 t$, plantio, DIRA Ribeiräo Preto, Estado de Säo Paulo, safra $86 / 87$

cultura G: cana-de-açücar TM, iha, produção $78 t, 2 \%$ corte, olRA Ribeirão Preto, Estado de São Paulo, safra $86 / 87$

cultura H: cana-de-açücar TM, 1ha, produção $60 t, 39$ corte, DIRA Ribeirão Preto, Estado de São Paulo, safra $86 / 87$

cultura 1: feijão das äguas TA, 1 ha, produção $10 \mathrm{sc,} \mathrm{OIRA}$ Sorocaba, Estado de são Paulo, safra $86 / 87$

cultura J: feijão das äguas TMA, 1 ha, produção 16 sc, DIRA Sorocaba, Estado de São Paulo, safra $86 / 87$ 
cultura K: milho. TMA, 1ha, produção $45 \mathrm{sc}, 60 \mathrm{~kg}$, sub-região Avarē, Estado de São Paulo, safra $86 / 87$

cultura L: milho TM, lha, produção $50 \mathrm{sc}, 60 \mathrm{~kg}$, sub-região Avaré, Estado de São Paulo, safra $86 / 87$ cultura M: milho TM, 1ha, produção $60 \mathrm{sc}, 60 \mathrm{~kg}$, DIRA Ribeirão Preto, Estado de São Paulo, safra $86 / 87$ cultura N: feijäo da seca TMA, 1 ha, produção $15 \mathrm{sc}, 60 \mathrm{~kg}$, DIRA Sorocaba, Estado de São Paulo, safra $85 / 86$ cultura 0: feijão da seca. TM, $1 \mathrm{ha}$, produção $16 \mathrm{sc}, 60 \mathrm{~kg}$, DIRA Sorocaba, Estado de São Paulo, safra $85 / 86$ cultura $P$ : feijão de inverno irrigado. TM, 1ha, produção $31 s c, 60 \mathrm{~kg}$, DIRA São José do Rio Preto, Estado de São Paulo, safra $85 / 86$

cultura Q: trigo TM, 1 ha, produção $19 \mathrm{sc}, 60 \mathrm{~kg}$, sub-região de Assis, Estado de São Paulo, safra $85 / 85$.

Com a finalidade de levar a cabo a anàlise de sensibilidade escolheram-se as variaveis que maior peso têm no custo operacional efetivo, por cultura. Observou-se cuidadosamente as matrizes dos coeficientes técnicos na estrutura de custo de produção, para depois analisar as exigenncias de insumos.

Dentro dessas variäveis consideradas as mais expresslvas dentro do custo, escolheu-se para simulação as que apresentaram uma participação maior ou igual a $7 \%$ no 
custo operacional efetivo (apēndice 1). Utilizaram-se as expressöes desenvolvidas na metodologia.

Nesta pesquisa a simulação testará os efeitos de variações nas quantidades de insumos empregados e variações no tempo de realização das operaçōes selecionadas no custo operacional efetivo.

3.2. Funçōes de distribuição de probabilidades das variäveis simuladas

Pode-se verificar, na tabela 2 , que a partir da indicação derivada dos resultados da anälise de sensibilidade foram selecionadas as seguintes variáveis mais relevantes consideradas aleatörias para serem simuladas, conforme a cultura.
$x 1$ - corte
$\times 11$ - adubo formulado $(5-25-25)$
x2 - carpa manual
$\times 12-$ adubo formulado $(20-5-20)$
x3 - colheita manual
$\times 13-$ adubo formulado $(4-30-10)$
$x^{4}$ - irrigação
x14- sulfato de amônia em cobertura
x5 - carregamento
$\times 15-$ mudas (toletes)
x6 - aração
x16- calcário
$x 7$ - semente
$\times 17-$ herbicida
$x 8$ - adubo formulado (4-14-8)
x18-fungicida sistêmico
$x 9$ - adubo formulado (5-20-20)
x19- gradeação
$\times 10-$ adubo formulado (19-5-19)
x20- pulverização 
35.

Tabela 2. Variàveis selecionadas para simulação e as respectivas culturas.

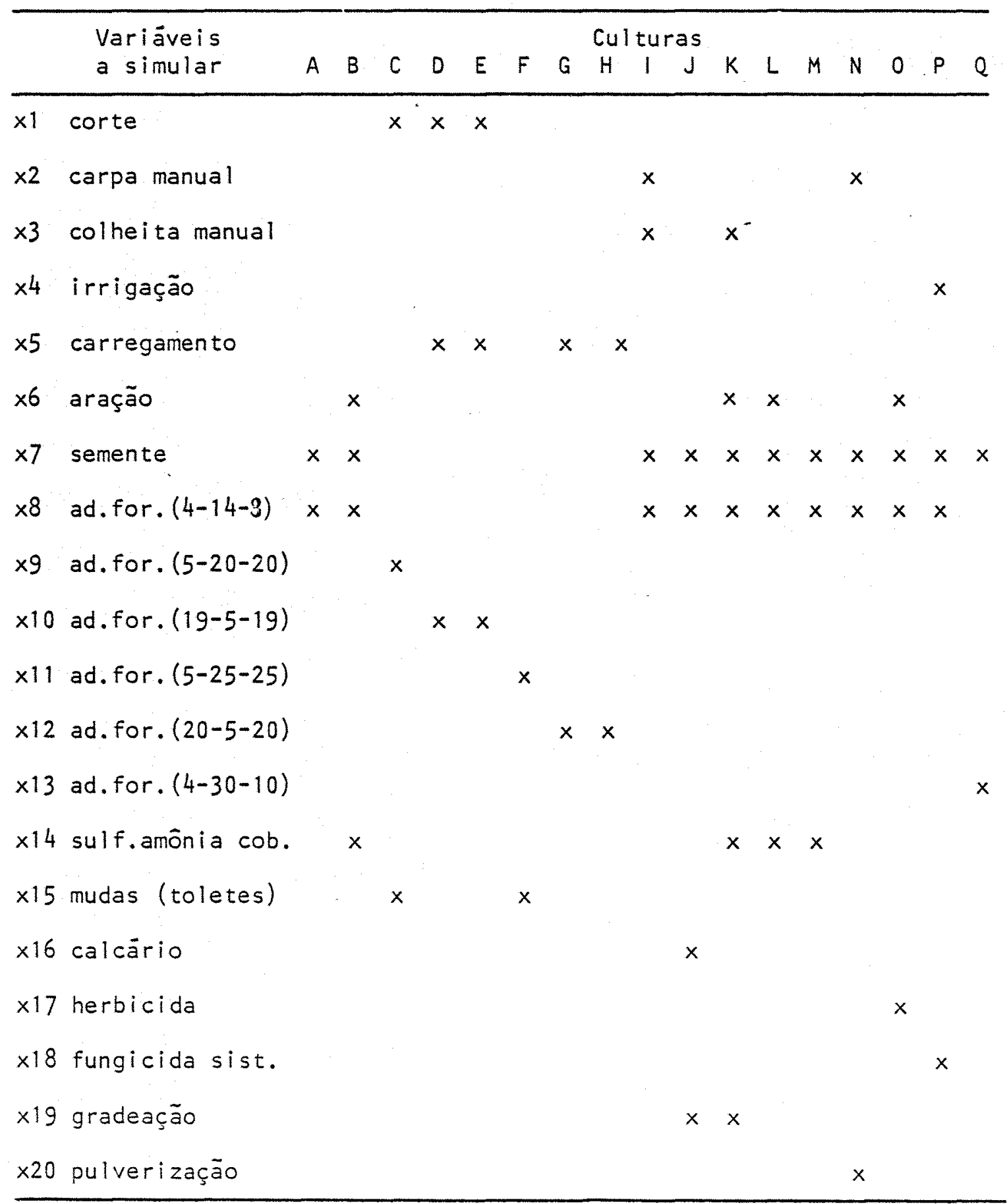


As variāveis consideradas estocästicas ou aleatörias $\times 4, \times 5, \times 6, \times 19$ e $\times 20$ envolvem a utillização de mais de um fator de produção. A operação irrigação. ( $x 4)$ vale-se de mão-de-obra comum e do equipamento de irrigação; a operação carregamento ( $\times 5)$, utiliza trator de rodas, tratorista e carregador; a operação aração abrange os fatores de produção tratorista, trator de rodas e arado; a operação gradeação necessita de tratorista, trator de rodas e. grade; a operação pulverização serve-se de mão-de-obra comum, tratorista, trator de rodas e pulverizador. Ao rodar - modelo no computador deverão ser considerados todos os fatores de produção associados à operação selecionada.

Devido ao fato de que os coeficientes não mudaram atraves dos anos descartou-se a possibilidade de confeccionar alguma distribuiçäo com intervalos de classes, visando a obter a freqüencia relativa tomada como medida de probabilidade. Isto teria permitido obter a função de distribuição derivada da função de densidade de probabilidade que, por sua vez, seria revelada pela representação gräfica do tipo histograma.

Pelo motivo exposto, decidiu-se usar a distribuição triangular para as variáveis aleatörias por esta possuir a vantagem de ser conveniente quando se dispöe de pouco conhecimento sobre as mesmas variäveis. 
Tomaram-se então os valores dos coeficientes tëcnicos apresentados pelo IEA, considerados os mais prováveis, e para cada caso estabeleceram-se 1 imites superior e inferior com base em informaçöes de tëcnicos (tabe1a 3). 


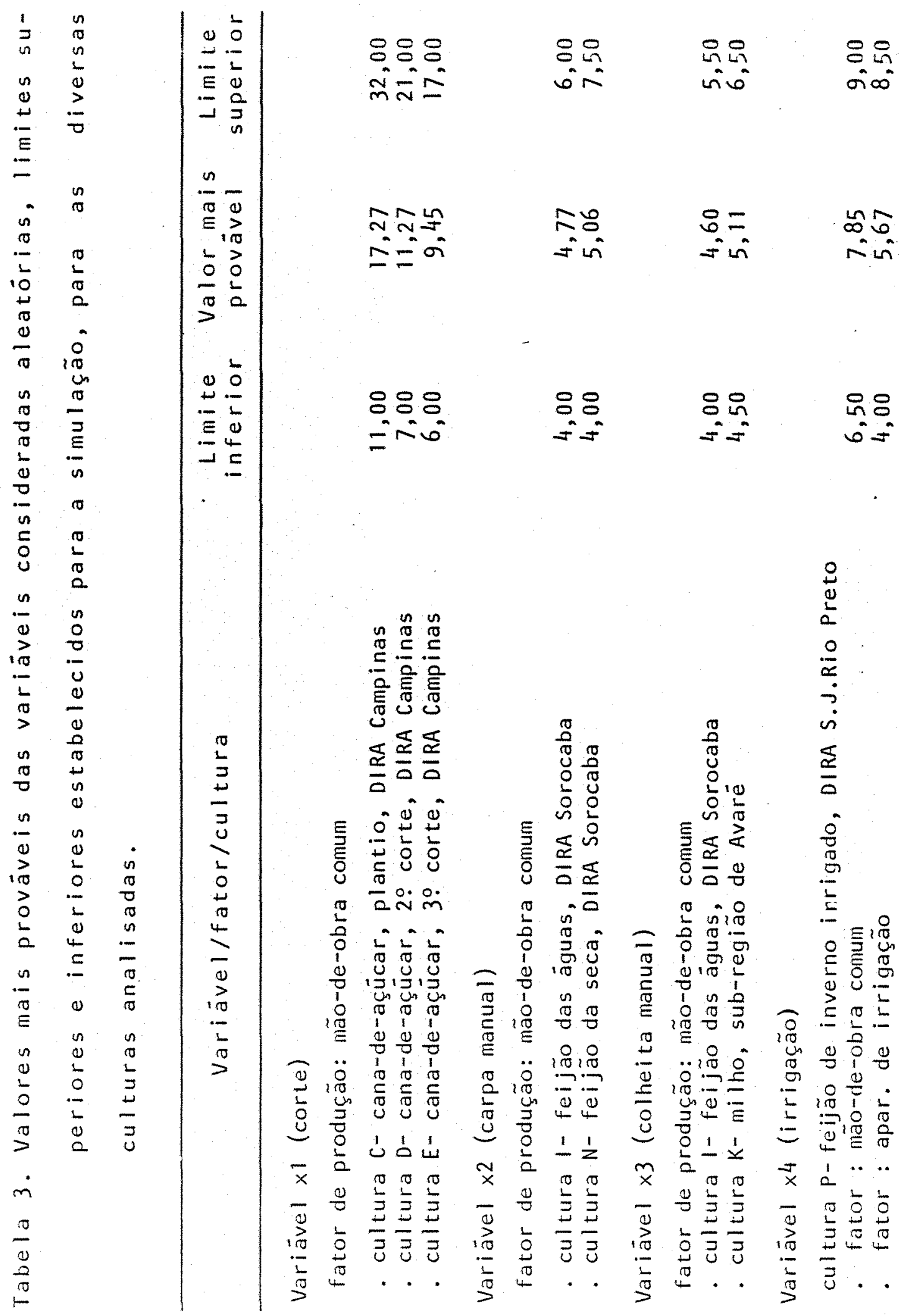




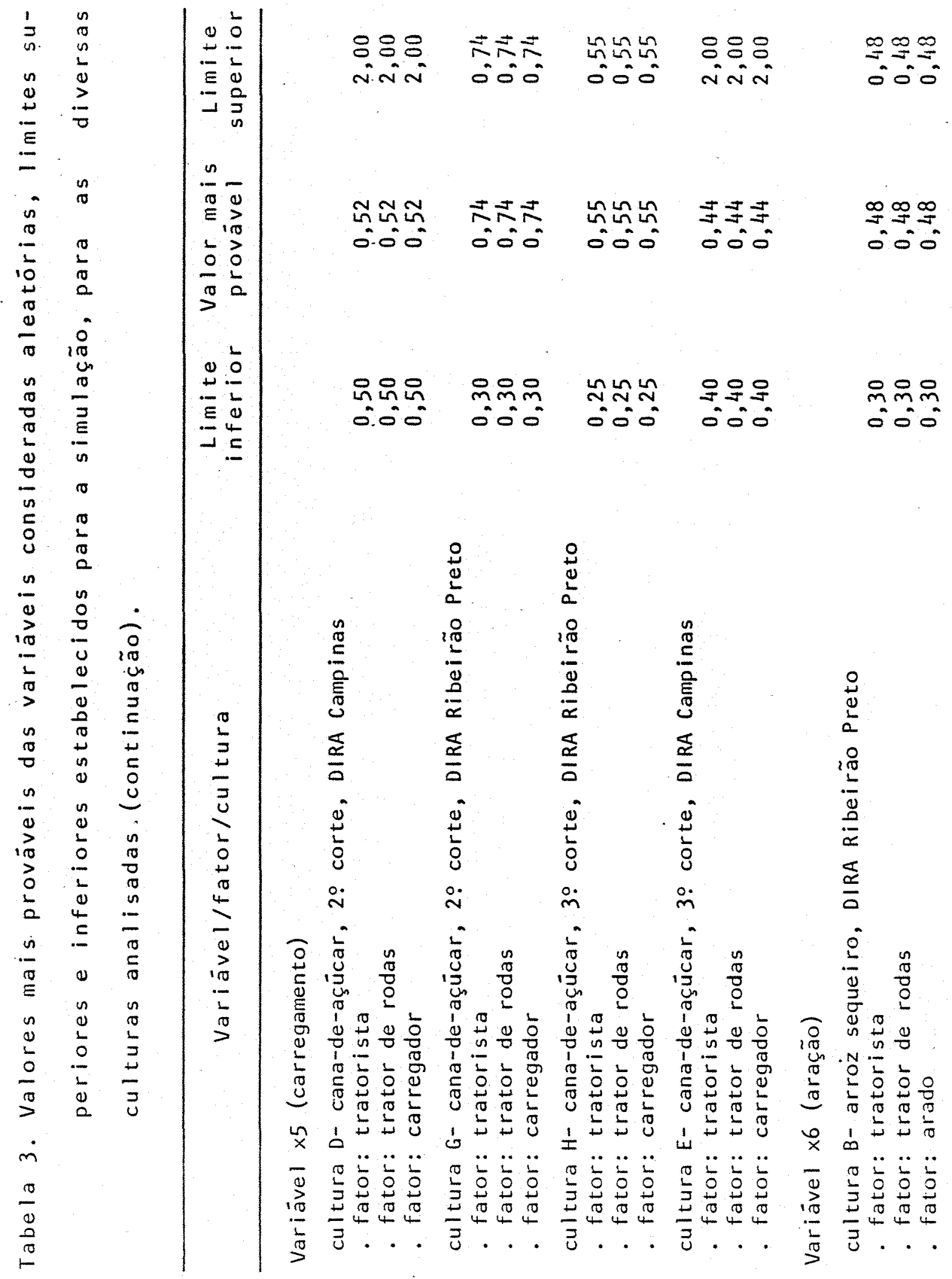


40.

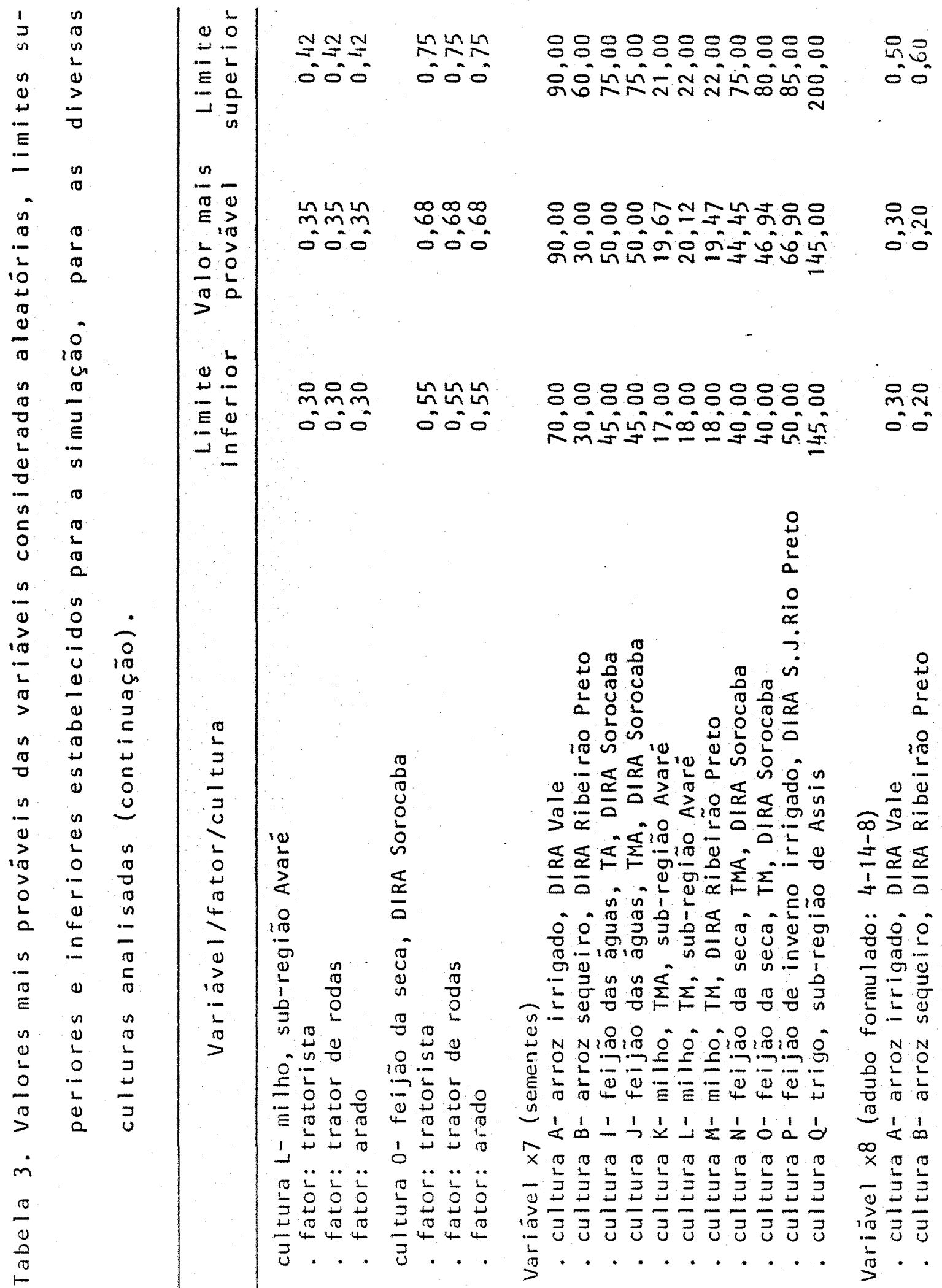


41.

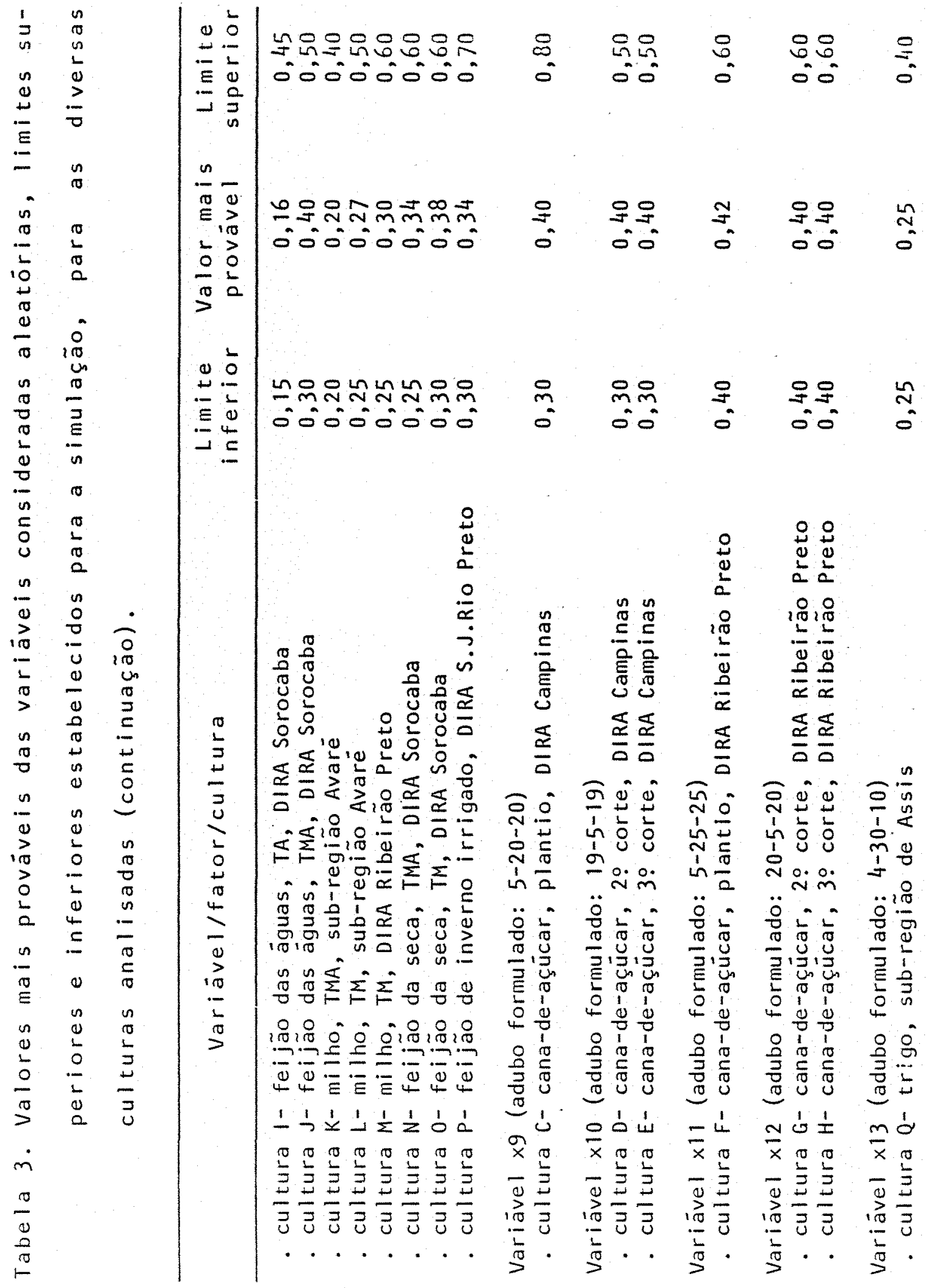


42.

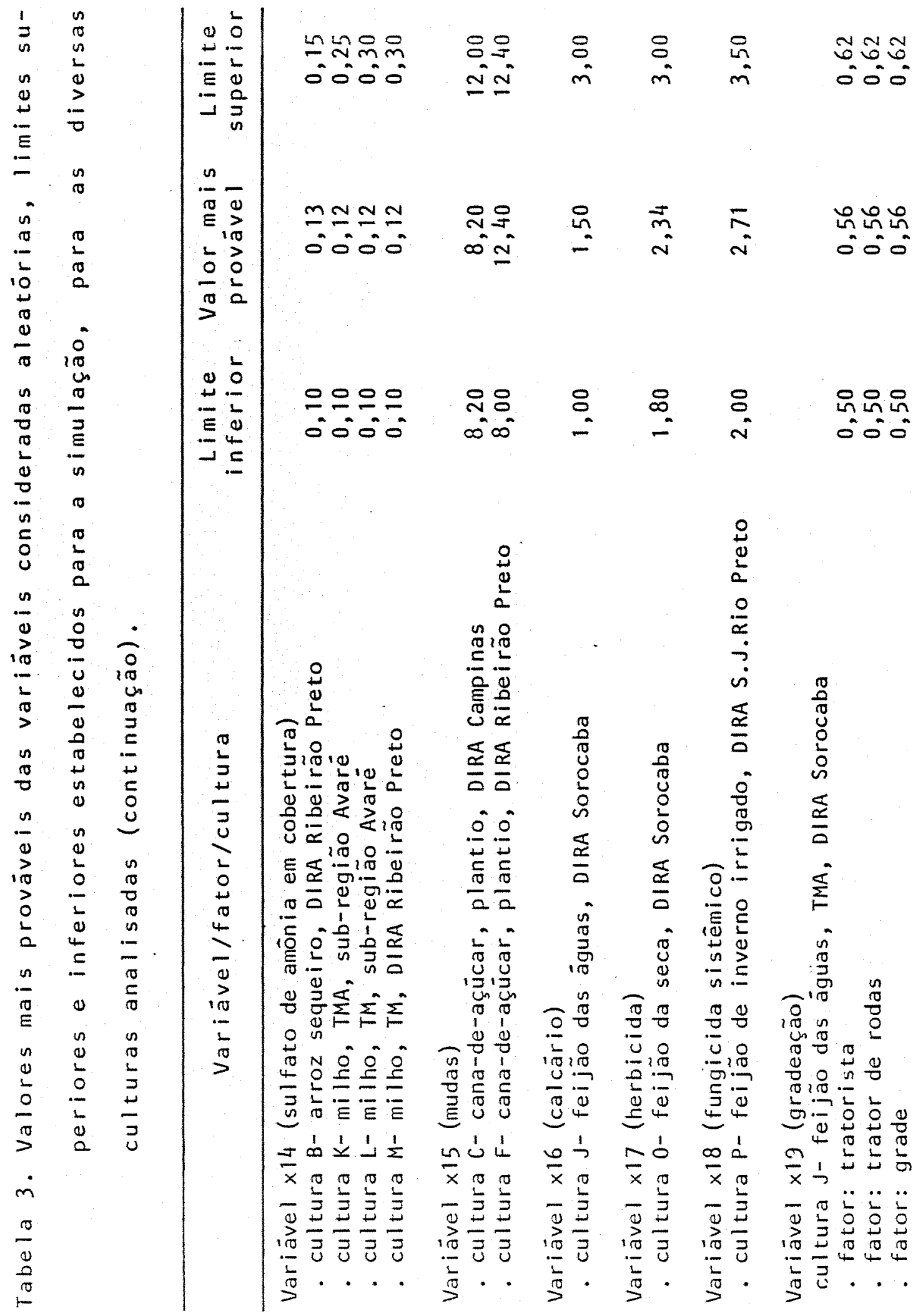




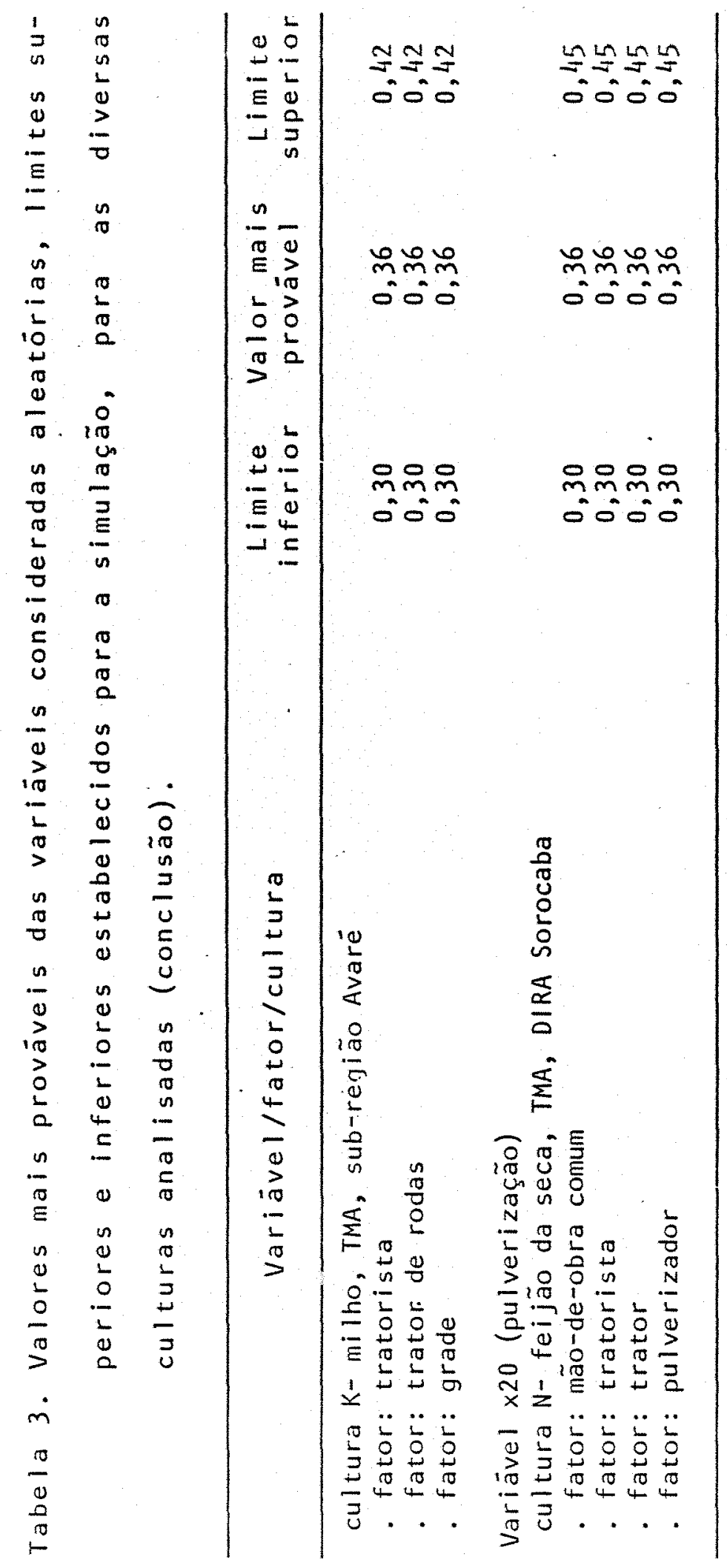


3.3. Simulação e anālise de riscos

o processo de simulação, incluindo a geração simultânea de valores ao acaso para as variäveis selecionadas, foi feita mediante a utilização de um programa desenvolvido para microcomputadores IBM/PC e compatíveis. - referido programa tem a finalidade de simular os cálculos da estimativa do custo de produção, partindo da distribuição de probabilidade de algumas variäveis selecionadas para simulação. o resultado é mostrado como freqüéncia do custo operacional efetivo, apōs, no caso, 10.000 simulações por cultura.

Foram calculadas a esperança do custo e o desvio padrão antes de efetuada a simulação, e o custo mëdio, juntamente com o desvio padräo estimado apōs a simulação, com a finalidade de testar o modelo. Tanto as médias das distribuiçōes como o desvio padräo no cälculo probabilístico ou estocāstico não diferiram significativamente dos cälculos deterministicos, provando assim a validade da simulação (tabela 4).

Em todas as culturas, com exceção da cultura cana-de-açücar em fase de plantio, observou-se uma assimetria positiva da distribuição do custo, influenciada de alguma forma pela assimetria positiva da maioria das distribuições triangulares das variäveis simuladas. 
Tabela 4. Esperança do custo e desvio padrão antes da simulação, custo médio e desvio padrão estimado apōs a simulação.

\begin{tabular}{|c|c|c|c|c|}
\hline Cultura & $\begin{array}{c}\text { Esperança } \\
\text { do custo }\end{array}$ & $\begin{array}{l}\text { Desvio } \\
\text { padräo }\end{array}$ & $\begin{array}{l}\text { Custo } \\
\text { medio }\end{array}$ & $\begin{array}{c}\text { Desvio padrão } \\
\text { estimado }\end{array}$ \\
\hline A & 5067,379 & 113,330 & 5066,660 & 112,160 \\
\hline$B$ & 2956,605 & 218,990 & 2955,325 & 219,905 \\
\hline C & 11067,490 & 404,750 & 11061,290 & 402,310 \\
\hline$D$ & 4350,590 & 318,130 & 4345,830 & 315,830 \\
\hline$E$ & 4087,500 & 322,720 & 4085,070 & 322,720 \\
\hline$F$ & 10317,060 & 233,627 & 10314,900 & 230,810 \\
\hline G & 4307,300 & 147,430 & 4306,120 & 145,830 \\
\hline$H$ & 3991,220 & 135,560 & 3990,430 & 134,140 \\
\hline 1 & 1863,640 & 161,990 & 1863,460 & 162,580 \\
\hline$J$ & 3441,930 & 142,660 & 3440,780 & 142,300 \\
\hline K & 2396,260 & 131,970 & 2397,031 & 131,200 \\
\hline$L$ & 2394,246 & 163,403 & 2393,807 & 163,448 \\
\hline$M$ & 2816,410 & 201,119 & 2812,950 & 199,800 \\
\hline N & 2684,550 & 144,066 & 2683,445 & 144,184 \\
\hline 0 & 3469,840 & 144,940 & 3466,077 & 145,245 \\
\hline$p$ & 8746,510 & 397,270 & 8742,490 & 395,640 \\
\hline$Q$ & 4230,470 & 150,700 & 4228,830 & 148,945 \\
\hline
\end{tabular}


Como foi assinalado anteriormente, os dados referentes ao nivel mínimo e mâximo para a construção da distribuição triangular das variäveis consideradas aleatörias foram conhecidos atravës de entrevistas com tëcnicos especialistas nas culturas em estudo. o coeficiente técnico apresentado pelo IEA foi considerado como o valor mais provável ou moda. Observou-se, na maioria das variàvis, que este ültimo valor esteve mais parto do limite mínimo, fazendo com que a distribuição dessas variäveis mostrasse uma cauda mais longa à direita.

Como resultado das simulaçöes obtiveram-se as distribuiçōes de freqüencia do custo operacional efetivo das diversas culturas e seus respectivos histogramas, as quais säo apresentadas no apêndice 2 (tabelas 1 a 17 ).

A probabilidade de ocorrência do custo nos intervalos de classe apresentados na primeira coluna é indicada pela freqüencia relativa, sendo possivel dizer qual a probabilidade do custo operacional efetivo do IEA ocorrer sob as condiçōes especificadas na anälise.

Das 17 planilhas de custo simuladas, correspondendo a cinco culturas analisadas em diversas DIRAs, somente nas culturas arroz irrigado (A), cana-de-açúcar de plantio (F) e 2 : corte (G) em Ribeirão Preto, o custo de produção do IEA encontrou-se incluído na classe modal. 
Por exemplo, o custo operacional efetivo analisado para a cultura arroz irrigado foi de Cz\$4975,68; verificou-se, conforme a tabela 1 do apendice 2 , que esse valor se encontra no intervalo de classe correspondente a classe modal, cuja probabilidade de ocorrencia é de $15,56 \%$. Com base na freqüencia relativa acumulada, conclui-se que existe $63,82 \%$ de probabilidade de que os agricultores obtenham custos maiores que $C z \$ 5010,00$ ( $1 \mathrm{imite}$ superior do intervalo de classe imediatamente acima da classe modal).

Todavia, os resultados da simulação para as culturas cana-de-açücar de plantio e 2 \% corte na DIRA de Ribeirão Preto, indicam respectivamente probabilidades de $36.09 \%$ e $59,15 \%$ de ocorrerem custos maiores do que o custo operacional efetivo do IEA (tabelas 6 e 7 do apendice 2).

Nesse sentido a interpretação dos resultados revela que as melhores estimativas de custo foram observadas nessas culturas.

Analisando os resultados da simulação para as culturas restantes atravēs da distribuiçäo de freqüēncia do custo, observou-se que o custo operacional efetivo em anälise estä concentrado nos intervalos de classes anteriores à moda, apresentando um considerävel grau de risco de se tomarem tais estimativas como base de decisões dos produtores. 
Na cultura B arroz de sequeiro, por exemplo, - custo estimado pelo IEA foi de $C z \$ 2622,14$, que se encontra no intervalo de classe de 2557 e 2644 , cuja probabilidade de ocorrer é apenas de 3,44\%. E tem-se $96,56 \%$ de probabilidade de acontecerem custos superiores a c $c \$ 2644,00$, indicando que o valor estimado pelo lEA dificilmente será atingido na prätica (tabela 2 do apêndice 2 ).

Em termos de politica agrícola, este aspecto merece anālise cuidadosa, tendo em vista que a política de preços mínimos visa, entre seus objetivos básicos, a es timular a produção e a dar suporte de renda aos produtores rurais quando o preço de mercado for muito reduzido.

A expectativa de ganhos econōmicos e o planejamento de curto prazo são feitos pelos pequenos produtores levando em conta, entre outros aspectos, qual o montante de gastos previstos para a proxima safra e quais as garantias de cobri-los, em que o preço minimo se traduz numa importante variävel para esta anälise.

Portanto, se se tomar o atual sistema de cálculo de custos do IEA, para a fixação de política de preço mínimo, obviamente o agricultor ver-se-ia francamente desestimulado. A simulação mostra que a probabilidade de os custos serem maiores do que os apresentados pelo IEA é bastante alta. 
E preciso considerar, evidentemente, que a avaliação do grau de risco depende das condições estabelecidas para a simulação, bem como os dados fornecidos pelos especialistas tomados como referencia: Mas, mesmo assim, ë uma evidência clara da necessidade de se avaliarem as estimativas de custos de produção de modo a tornä-las mais pröximas da realidade dos produtores, que trabalham constantemente sob condiçōes de risco. 


\section{RESUMO, CONCLUSOES E SUGESTOES}

Para atingir os objetivos propostos na presente pesquisa foi utilizado o método de simulação Monte Carlo, cujas características são:

a) ë uma técnica aplicada a problemas que têm base probabilística ou estocástica;

b) è um mëtodo que requer a definição das distribuições de probabilidade das variäveis e a geração de nümeros aleatörios a partir dessas distribuições;

c) permite obter a distribuiçāo de freqüência da variävel dependente em anälise, e fazer os cálculos dos indicadores que permitam medir o risco (como desvio padräo, coeficiente de variação, etc.).

Através de uma anälise dos efeitos das variaçōes aleatörias nos coeficientes tëcnicos sobre os custos tentou-se analisar a qualidade das estimativas apresentadas pelo IEA. E, assim, analisar as implicaçōes präticas da utilização dessas estimativas como base de política de preços mínimos. 
Os resultados obtidos da aplicação da simulação em relação às estimativas de custo do IEA, permitiram verificar que:

a) levando em conta os supostos implícitos na simulação e os dados tomados como referencia, as estimativas do IEA subestimam consideravelmente as estimativas. calculadas considerando o risco. Realizada a simulação, a maioria das planilhas de custo simuladas apresentaram uma alta probabilidade de os seus custos, agora sob condiçōes de risco, serem maiores do que as estimativas anteriormente determinadas pelo IEA;

b) as melhores estimativas foram encontradas nas culturas de arroz irrigado, cana-de-açücar na fase de plantio e $2 \%$ corte na DIRA de Ribeirão Preto.

Dos resultados da simulação e análise de risco, obtidos atravès desta metodologia, è possivel formular as seguintes conclusões em relação às conseqüencias, de uma possível fixação de preços mínimos com base no atual sistema de călculo do custo.

a) Na maioria das planilhas de custos analisadas verificou-se uma alta probabilidade de acontecerem custos maiores do que os estimados, indicando que existe um alto risco para os agricultores de que os formuladores de politica agricola fixem preços mínimos abaixo de seus 
custos operacionais. Portanto, o objetivo da politica de preços mínimos de garantir aos produtores cobertura pelo menos de seus custos operacionais de produção fica prejudicado se for baseada nas estimativas do IEA.

b) Outro efeito desfavorävel ao agricultor poderá ocorrer na medida em que as instituiçōes financeiras utilizem as estimativas oficiais de custo do IEA como base para cálculo dos financiamentos de custeio. Custos subestimados podem levar a uma restrição de crëdito de custeio.

Conclui-se, também, que a utilização do mëtodo de Monte Carlo é viável e ütil como meio de introduzir o risco nas estimativas de custos e pode reduzir a margem de risco na tomada de decisão das instituições ligadas ao setor e dos agricultores.

SUGESTOES

As conclusões dos resultados obtidos na presente pesquisa suscitam algumas sugestões que são apresentadas a seguir.

$$
\text { Considerando-se que o objetivo primordial }
$$
das estimativas dos custos de produção é fornecer um parámetro de curto prazo, tanto ao produtor como aos agentes financeiros e órgãos estatais e privados atuantes na poli- 
53.

tica agrícola, para suas tomadas de decisão, é fundamental que se considere a aleatoríedade de pelo menos alguns coeficientes tëcnicos componentes do custo de produção. Sugere-se entāo, que a simulação seja introduzida como técnica de analise da qualidade das estimativas de custos de produção.

Ademais, outras pesquisas neste sentido devem ser feitas, considerando aleatörio o rendimento obtido e levando em consideração a dependência entre variāveis aleatörias simuladas. E de interesse, tambēm, que um nümero maior de produtos seja contemplado, incluindo as culturas perenes e semi-perenes, vegetais e animais. 
ARRUDA, S.T. A cultura da seringueira em São Paulo - viabí lidade econômica. São Paulo, Instituto de Economia Agrícola, 1985. 33 p. (Relatörio de Pesquisa).

AZEVEDO Fo, A.J.B.V. \& BELO, F.R. Avaliação de alternativas energéticas: o gäs metano-biogás, como substituto dos combustiveis convencionais na agricultura. In: CONFEREN CIA LATINOAMERICANA DE ECONOMIA AGRTCOLA. Pi.raciCaba, 1984. $31 \mathrm{p}$.

CONTADOR, C.R. Avaliação social de projetos. São Paulo, $\underline{A}$ tlas, $1981,301 \mathrm{p}$.

CORVALAN, L.M. O risco na escolha de cultivares de milho. Piracicaba, SP, 1987. 135 p. (Mestrado - Escola Superior de Agricultura "Luiz de Queiroz"/USP).

HOFFMANN, R.; NORONHA, J.F.de E CORVALAN, M.X. Manual de Simulação de Custos. Piracicaba, ESALQ/USP, 1987.

LEME, R.A.S. Curso de estatistica elementar, 3. ed, Rio de Janeiro, Ao Livro Tëcnico, 1972. $292 \mathrm{p}$. 
MATSUNAGA, M.; BENELMANS, P.F.; TOLEDO, P.E.N.; DULLEY, D.R.; OKAWA, M. E PEDROSO, I.A. Metodologia de custo de produção utilizado pelo IEA. Agricultura em São Paulo, São Paulo, 23(1):123-139, 1976 .

MELLo, N.T.C.de. Custo de produção e anălise da renda da cultura de arroz de sequeiro no municipio de 0limpia, DIRA de São José do Rio Preto, ano agrícola 1973/74. São Paulo, IEA, 1978. 26 p. (Relatörio de Pesquisa, 11).

MELLO, N.T.C.; RIBEIRO, J.R.; CHABARIBERY, D.; ARRUDA, T.D.; CAMARgO, J.R.V. E OKAWA, H. Custo de produção: estimativas e coeficientes técnicos das principais atividades agropecuárias do Estado de São Paulo, safra 1985/86. Informaçōes Econômicas, São Paulo, 15(7): 19$-25,1985$.

NAYLOR, T.H.; BALINTFLY, J.L.; BURDICK, D.S. \& CHU, K. Tẽc nicas de Simulação em Computadores. Petrópolis, Vozes, 1971. $402 \mathrm{p}$.

NEVES, E.M. Análise econômica do investimento em condiçōes de risco na cultura da borracha. Piracicaba, 1984. 171 p. (Livre-Docència - Escola Superior de Agricultú ra "Luiz de Queiroz"/USP).

NORONHA, J.F.de. Projetos Agropecuärios - Administracão financelra, orcamentação e avaliacão económica. São Pau 10. Editora Atlas, $1984.269 \mathrm{p}$. 
NORONHA, J.F.de. O sistema de avaliação económica de projetos agropecuärios na politica brasileira de crédito rural. Piracicaba, 1981. (Livre-Docēncia-Escola Superior de Agricultura "Luiz de Queiroz"/USP).

PIRES, Z.A. Função de custo e anälise de renda da cultura de trigo no Estado de São Paulo, 1975. São Paulo, IEA, 1979. 22 p. (Relatörio de Pesquisa, 7).

REUTLINGER, S. Techniques for project appraisal under uncertainly. Baltimore, The Johns Hopkins Univ. Press, 1979. $95 \mathrm{p}$.

SA, J.M.de. Anälise econômica da engorda de bovinos i. em confinamento em Goiàs. Piracicaba, 1985. $112 \mathrm{p}$. (Mes trado - Escola Superior de Agricultura "Luiz de Quei$r o z^{11} /$ USP).

SOLOMON, M.S. Anälise de projeto para o crescimento econó mico. Rio de Janeiro, APEC, 1970. $590 \mathrm{p}$.

SPIEGEL, M.R. Probabilidade e estatística. São Paulo, Mc Graw-Hill do Brasil, 1978. $518 \mathrm{p}$.

WOILER, S. E MATHIAS, W.F. Projetos: planejamento, elaboração e anälise. São Paulo, Atlas, 1986. 294 p. 
$B$ IBLIOGRAFIA RECOMENDADA

CAMARGO, J.R.V.de; DULLEY, R.D.; CHABARIBERY, R.A. \& JUNIOR, D.R. Estimativa de custo operacional e coeficientes técnicos das principais explorações agropecuárias, Estado de São Paulo, safra 1981/82. Informacōes Econômicas, São Paulo, $11(7): 19-101,1981$.

DULLEY, R.D.M.S. Viabilidade econōmica do sistema de pro dução na agricultura alternativa. In: GORGATTI NETO, A. E CRUZ, E. Experiencia brasileira de pesquisa económica em energia para o setor rural. Brasilia, EMBRA PA, 1984, P. $191-215$.

LEITE, C.R.S.; MELLO, C.N.T; VEIGA F.A.; MATSUNAGA, M; SE VER, A.F. Anälise de alocação de recursos na produção de arroz de sequeiro, município de 0limpia, Estado de São Paulo, 1973/74. São Paulo, IEA, 1979. 17 p. (Relatörio de pesquisa, 10 ).

MUELLeR, C.C. Pecuäria de corte no Brasil Central. Resultados das simulações com modelos de programação linear. Brasilia, 1985. 71p. (Textos para discussão, 29). 


\section{A P E N D I CE 1}

PARTICIPAÇÃO PERCENTUAL DOS COEFICIENTES TECNICOS

SELECIONADOS NO CUSTO OPERACIONAL EFETIVO

DO FLUXO ORIGINAL, PARA CADA CULTURA 
Cultura do arroz irrigado (A), TM, 1ha, produção $55 \mathrm{sc}$, $60 \mathrm{~kg}$, DIRA Vale, Estado de Säo Paulo, safra $86 / 87$.

Operaçōes
Participação do coeficiente tëcnico no COE (\%)

1. Limp. e rebaixamento valetas

4,70

mão-de-obra comum

2: Limp. química de valetas

5,43

mão-de-obra comum

0,56

Eratorista

0,60

trator de rodas

3,81

conj. pulverização

0,46

3. Gradeação

5,07

tratorista

0,62

trator de rodas

$.3,82$

grade

0,63

4. Nivelamento

4,72

tratorista

0,62

trator de rodas

3,88

plaina

0,22

5. Sementes

15,68

6. Adubo formulado (4-14-8)

13,52 
Cultura do arroz sequeiro (B), TMA, 1 ha, produção $27 \mathrm{sc}$., $60 \mathrm{~kg}$, DIRA Ribeiräo Preto, Estado de São Paulo, safra $86 /$ 187.

\section{Operaçōes}

1. Carpa manual mão-de-obra comum

2. Aração

tratorista

trator de rodas

arado

3. Gradeação

tratorista

trator de rodas

grade

4. Sementes

5. Adubo formulado $(4-14-8)$

6. Sulfato de amônia em cobertura
Participação do coeficiente tëcnico no COE (\%) 
Cultura cana-de-açücar (C), TM, 1ha, produção 95t, plantio, DIRA Campinas, Estado de São Paulo, safra $86 / 87$.

\section{Operações}

1. Carpa manual

2. Corte mão-de-obra comum

3. Arrancamento da soca tratorista

trator de rodas

arado

4. Plantio de mudas mão-de-obra

tratorista

trator de rodas

carreta

5. Carregamento

tratorista

trator de rodas

carregador
Participação do coeficiente técnico no COE $(\%)$
1,42

7,23

7,23

4,60

0,50

3,87

0,23

4,93

0,68

0,47

3,55

0,23

5,90

0,53

4,12

1,25

6. Mudas

12,97

7. Adubo formulado $(5-20-20)$

11,50 
Cultura cana-de-açücar (D), TM, 1 ha, produção $62 t, 29$ corte, DIRA Campinas, Estado de São Paulo, safra $86 / 87$. técnico no COE (\%)

1. Carpa manual

$$
5,17
$$

mão-de-obra comum

$$
5,17
$$

2. Corte 12,63

mão-de-obra comum

12,63

3. Carregamento

$$
10,28
$$

tratorista

0,93

trator de rodas

7,18

carregador

2,17

4. Adubo formulado $(19-5-19)$ 
Cultura cana-de-açūcar (E), TM, 1ha, produção $52 t$, $3:$ corte, DIRA Campinas, Estado de São Paulo, safra $86 / 87$.

Operações

1. Carpa manual mão-de-obra comum

2. Corte mäo-de-obra comum

3. Carregamento tratorista trator de rodas carregador

4. Adubo formulado $(19-5-19)$
Participação do coeficiente técnico no COE (\%) 
Cultura cana-de-açücar (F), TM, Tha, produção $100 t$, plantio, DIRA Ribeiräo Preto, Estado de São Paulo, safra 86/87.

Operaçōes

1. Corte e seleção de mudas mão-de-obra comum

2. Carpa manual mão-de-obra comum

3. Plantio de mudas mão-de-obra comum tratorista trator de rodas carreta

4. Carregamento tratorista trator de rodas carregador
Participação do coeficiente técnico no COE (\%) 
Cultura cana-de-açücar (G), TM, 1 ha, produção $78 t, 29$ corte, DIRA Ribeirão Preto, Estado de São Paulo, safra 86/87.

$$
\text { Operações }
$$

$$
\begin{gathered}
\text { Participação do coeficiente } \\
\text { técnico no COE }(\%)
\end{gathered}
$$

1. Carpa manual

$$
3,17
$$

mäo-de-obra comum

3,17

2. Carregamento

11,00

tratorista

0,92

trator de rodas

7,75

carregador

2,33

3. Adubo formulado $(20-5-20)$ 
Cultura cana-de-açücar (H), TM, 1ha, produção $60 t$, $30^{\circ}$ corte, DIRA Ribeirão Preto, Estado de São Paulo, safra 86/87. Operações técnico no COE (\%)

1. Carpa manual

3,73

mão-de-obra comum

3,73

2. Carregamento

24,35

tratorista

0,90

trator de rodas

21,15

carregador

2,30

3. Adubo formulado $(20-5-20)$

27,12 
Cultura feijão das äguas (1), TA, 1 ha, produção $10 \mathrm{sc}$, $60 \mathrm{~kg}$, DIRA Sorocaba, Estado de São Paulo, safra $86 / 87$.

$$
\text { Operações }
$$

Participação do coeficiente tëcnico no COE (\%)

1. Carpa manual

12,38

mão-de-obra comum

12,38

2. Colheita manual

11,95

mäo-de-obra comum

11,95

3. Aração

6,47

mão-de-obra comum

4,20

animal

1,85

arado

0,42

4. Sementes

18,05

5. Adubo formulado $(4-14-8)$

22,33 
Cultura feijão das äguas (J), TMA, 1 ha, produção $16 \mathrm{sc}$, $60 \mathrm{~kg}$, DIRA Sorocaba, Estado de São Paulo, safra $86 / 87$.

\section{Operaçōes}

1. Carpa manual

mão-de-obra comum

2. Colheita manual mão-de-obra comum

3. Aração tratorista

trator de rodas arado

4. Gradeação tratorista trator de rodas grade
Participação do coeficiente técnico no COE (\%)

5,98

5,98

4,12

4,12

5,15

0,70

4,01

0,38

5. Sementes

8,73

6. Calcärio

10,83

7. Adubo formulado $(4-14-8)$

2698 
Cultura milho (K), TMA, 1ha, produção $45 \mathrm{sc}, 60 \mathrm{~kg}$, sub-região Avarē, Estado de São Paulo, safra 86/87.

\section{Operações}

1. Carpa manual mão-de-obra comum

2. Colheita manual mão-de-obra comum

3. Aração

tratorista

trator de rodas

arado

4. Gradeação

tratorista.

trator de rodas

grade
Participação do coeficiente tëcnico no COE (\%)
6,45

6,45

9,68

9,68

7,57

1,02

6,00

0,55

5. Sementes

10,28

6. Sulfato de amōnia em cobertura

12,32

7. Adubo formulado (4-14-8)

22,42 
Cultura milho (L), TM, 1ha, produção $50 \mathrm{sc,} 60 \mathrm{~kg}$, sub- região Avarē, Estado de São Paulo, safra 86/87.

$$
\text { Operações }
$$

Participação do coeficiente técnico no, COE $(\%)$

1. Aração 7,07

tratorista

0,95

trator de rodas

5,60

arado

0,52

2. Carpa mecânica

6,53

tratorista

0,92

trator de rodas

5,43

cultiv. mecanizado

0,18

3. Sementes

10,93

4. Sulfato de amônia em cobertura

12,82

5. Adubo formulado (4-14-8)

28,63 
Cultura milho (M), TM, tha, produção $60 \mathrm{sc}, 60 \mathrm{~kg}$, DIRA Ri beirão Preto, Estado de São Paulo, safra $86 / 87$.

\section{Operaçöes}

Participação do coeficiente tëcnico no COE (\%)
1. Aração

tratorista

trator de rodas

arado

2. Gradeação

tratorista

trator de rodas

grade

3. Carpa mecânica

tratorista

trator de rodas

cult. mecanizado
6,58

0,97

$\overline{5}, 13$

0,48

4,58

0,63

3,38

0,57

4,13

0,63

3,38

0,12

4. Sementes

8,93

5. Sulfato de amōnia em cobertura

10,82

6. Adubo formulado $(4-14-8)$

26,85 
Cultura feijão da seca (N), TMA, 1ha, produção $15 \mathrm{sc}$, $60 \mathrm{~kg}$, DIRA Sorocaba, Estado de São Paulo, safra 85/86.

\section{Operações}

Participação do coeficiente tëcnico no COE (\%)

1. Carpa manual mão-de-obra comum

7,85

2. Arrancamento

6,42 mão-de-obra comum

6,42

3. Aração

6,21

tratorista

0,68

trator

5,23

arado

0,30

4. Pulverização

7,30

mão-de-obra comum

0,57

tratorista

0,73

trator

5,53

pulverizador

0,47

5. Sementes

14,58

6. Adubo formulado (4-14-8)

23,05 
Cultura feijão da seca (0), TM, 1ha,: produção $16 \mathrm{sc}, 60 \mathrm{~kg}$; DIRA Sorocaba, Estado de São Paulo, safra $85 / 86$.

\begin{tabular}{|c|c|c|}
\hline Operações & $\begin{array}{c}\text { Participação do } \\
\text { técnico no }\end{array}$ & $\begin{array}{l}\text { coeficiente } \\
\operatorname{COE}(\%)\end{array}$ \\
\hline 1. Carpa manual & & 4,12 \\
\hline mão-de-obra comum & 4,12 & \\
\hline 2. Arrancamento & & 4,60 \\
\hline mäo-de-obra & 4,60 & \\
\hline 3. Aração & & 9,35 \\
\hline tratorista & 1,03 & \\
\hline trator & 7,87 & \\
\hline arado & 0,45 & \\
\hline 4. Semente & & 11,57 \\
\hline 5. Adubo formulado $(4-14-8)$ & & 19,37 \\
\hline 6. Herbicida & & 18,57 \\
\hline
\end{tabular}


Cultura feijäo de inverno irrigado (P), TM, 1ha, produção $31 \mathrm{sc}, 60 \mathrm{~kg}$, DIRA São Josē do Rio Preto, Estado de São Paulo, safra $85 / 86$.

\section{Operaçōes}

1. Adubação em cobertura mäo-de-obra comum padiola

2. Irrigação mão-de-obra comum apar. de irrigação

3. Colheita (arr. e amont.)

4. Pulverização mão-de-obra comum tratorista trator pulverizador
Participação do coeficiente tëcnico no COE (\%)

$$
4,80
$$

22,17
1,00

0,02
1,02

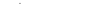

$$
3,17
$$

5,14

0,42

0,53

3,87

0,32

5. Sementes

9,12

6. Adubo formulado (4-14-8)

9,77

7. Fungicida sistêmico 
Cultura trigo (Q), TM, 1 ha, produção $19 \mathrm{sc}, 60 \mathrm{~kg}$, sub-região Assis, Estado de São Paulo, safra $85 / 86$.

Operaçōes

Participação do coeficiente técnico no COE (\%)

1. Reforma do terraço

$$
4,4
$$

tratorista

0,33

trator de rodas

3,95

arado

0,12

2. Gradeação

4,53

tratorista

0,33

trator de rodas

3,95

grade

0,25

3. Sementes

22,72

4. Adubo formulado $(4-30-10)$

20,12 


\section{A PENDICE 2 \\ DISTRIBUIÇÃO DE FREQÜENCIAS DO CUSTO E HISTO- \\ GRAMAS PARA AS CULTURAS EM ESTUDO}


Tabela 1. Distribuição de freqüencias de custo, para a cultura arroz irrigado, TM, Dira Vale (A).

\begin{tabular}{lrrrr}
\hline $\begin{array}{c}\text { Limite } \\
\text { inferior }\end{array}$ & $\begin{array}{c}\text { Limite } \\
\text { superior }\end{array}$ & Freqüencia & $\begin{array}{r}\text { Freqüencia } \\
\text { relativa }\end{array}$ & $\begin{array}{r}\text { Freqüencia } \\
\text { relativa } \\
\text { acumulada }\end{array}$ \\
\hline 4800,00 & 4842,00 & 26,00 & 0,26 & 0,26 \\
4842,00 & 4884,00 & 213,00 & 2,13 & 2,39 \\
4884,00 & 4926,00 & 628,00 & 6,28 & 8,67 \\
4926,00 & 4968,00 & 1195,00 & 11,95 & 20,62 \\
4968,00 & 5010,00 & 1556,00 & 15,56 & 36,18 \\
5010,00 & 5052,00 & 1362,00 & 13,62 & 49,80 \\
5052,00 & 5094,00 & 1301,00 & 13,01 & 62,81 \\
5094,00 & 5136,00 & 1013,00 & 10,13 & 72,94 \\
5136,00 & 5178,00 & 888,00 & 8,88 & 81,82 \\
5178,00 & 5220,00 & 706,00 & 7,06 & 88,88 \\
5220,00 & 5262,00 & 534,00 & 5,34 & 94,22 \\
5262,00 & 5304,00 & 322,00 & 3,22 & 97,44 \\
5304,00 & 5346,00 & 174,00 & 1,74 & 99,18 \\
5346,00 & 5388,00 & 72,00 & 0,72 & 99,90 \\
5388,00 & 5430,00 & 10,00 & 0,10 & 100,00 \\
\hline Total & & 10000,00 & 100,00 & \\
\hline
\end{tabular}

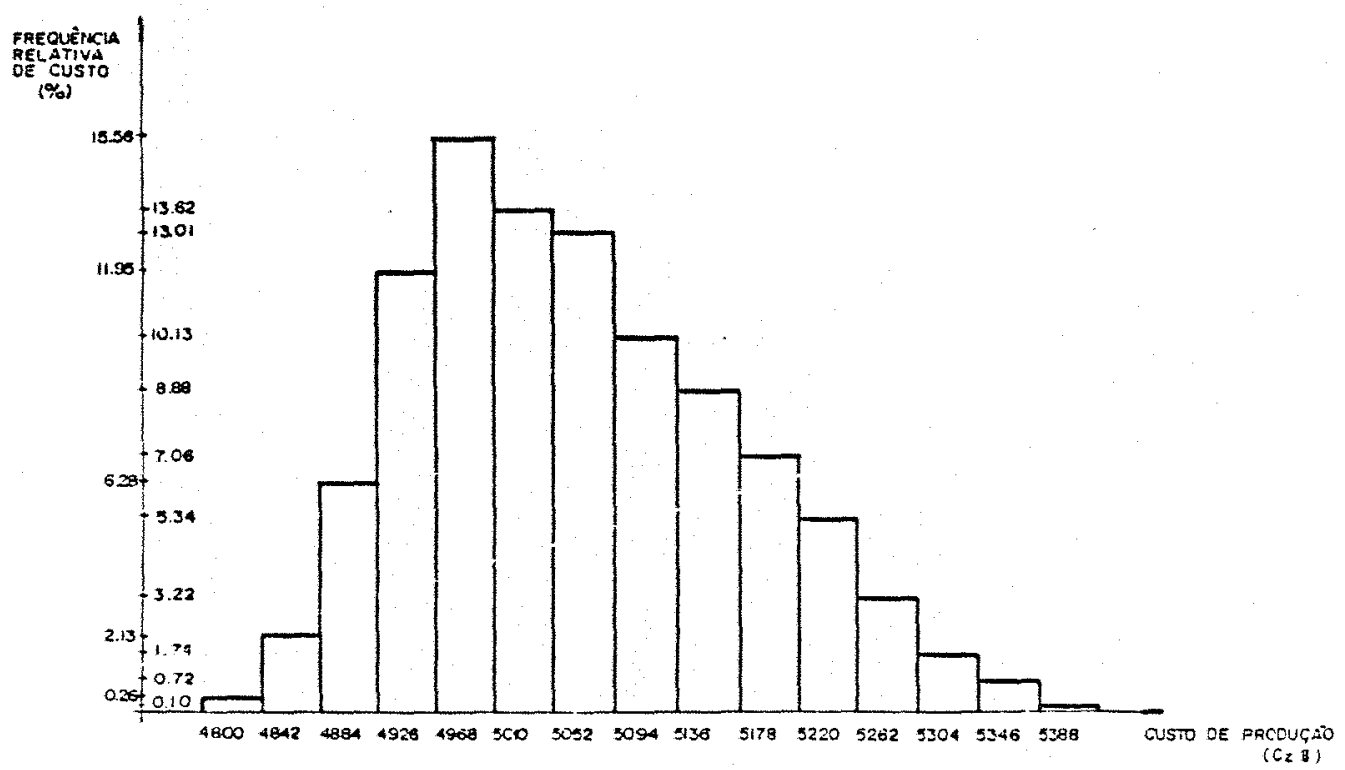

Histograma da distribuição da frequència do custo para a cultura A. 
Tabela 2. Distribuição de freqüencias de custo, para a cultura arroz sequeiro TM, DIRA Ribeiräo preto (B)

\begin{tabular}{lcrrr}
\hline $\begin{array}{c}\text { Limite } \\
\text { inferior }\end{array}$ & $\begin{array}{c}\text { Limite } \\
\text { superior }\end{array}$ & Freqüencia & $\begin{array}{c}\text { Freqüencia } \\
\text { relativa }\end{array}$ & $\begin{array}{r}\text { Freqüencia } \\
\text { relativa } \\
\text { acumulada }\end{array}$ \\
\hline 2470,00 & 2557,00 & 3,00 & 0,03 & 0,03 \\
2557,00 & 2644,00 & 341,00 & 3,41 & 3,44 \\
2644,00 & 2731,00 & 1284,00 & 12,84 & 16,28 \\
2731,00 & 2818,00 & 1648,00 & 16,48 & 32,76 \\
2818,00 & 2905,00 & 1476,00 & 14,76 & 47,52 \\
2905,00 & 2992,00 & 1309,00 & 13,09 & 60,61 \\
2992,00 & 3079,00 & 1125,00 & 11,25 & 71,86 \\
3079,00 & 3166,00 & 899,00 & 8,99 & 80,85 \\
3166,00 & 3253,00 & 727,00 & 7,27 & 88,12 \\
3253,00 & 3340,00 & 561,00 & 5,61 & 93,73 \\
3340,00 & 3427,00 & 380,00 & 3,80 & 97,53 \\
3427,00 & 3514,00 & 191,00 & 1,91 & 99,44 \\
3514,00 & 3601,00 & 46,00 & 0,46 & 99,90 \\
3601,00 & 3688,00 & 10,00 & 0,10 & 100,00 \\
3688,00 & 3775,00 & 0,00 & 0,00 & 100,00 \\
\hline Total & \multicolumn{5}{c}{} \\
\hline
\end{tabular}

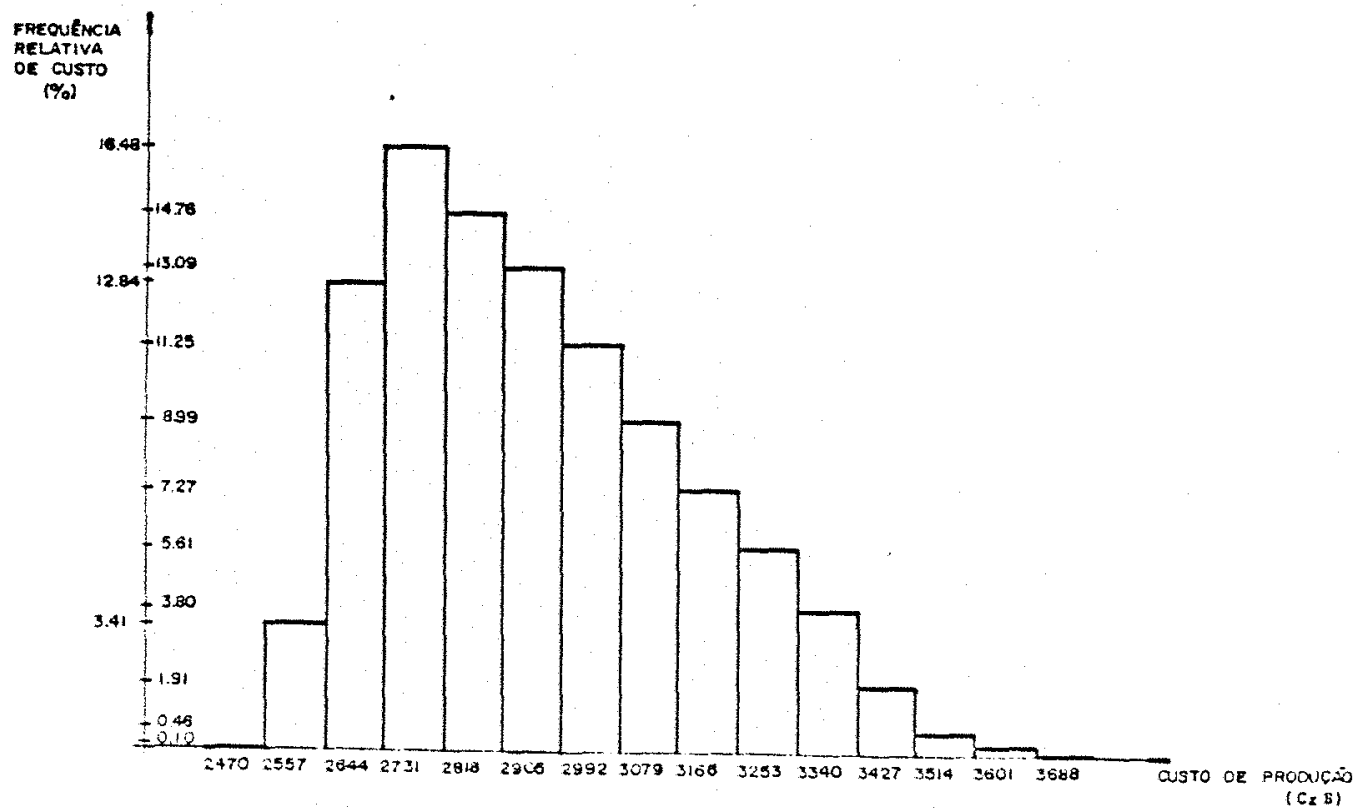

Histograma da distribuição de freqüencia de custo para a cultura B. 
Tabela 3. Distribuição de freqüèncias de custo, para a cultura cana-de-açũcar, TM, plantio, DIRA Campinas (C).

\begin{tabular}{lrrrr}
\hline $\begin{array}{c}\text { Limite } \\
\text { inferior }\end{array}$ & $\begin{array}{c}\text { Limite } \\
\text { superior }\end{array}$ & Freqüencia & $\begin{array}{r}\text { Freqüencia } \\
\text { relativa }\end{array}$ & $\begin{array}{r}\text { Freqüencia } \\
\text { relativa } \\
\text { acumulada }\end{array}$ \\
\hline 9800,00 & 10003,00 & 0,00 & 0,00 & 0,00 \\
10008,00 & 10216,00 & 44,00 & 0,44 & 0,44 \\
10216,00 & 10424,00 & 352,00 & 3,52 & 3,96 \\
10424,00 & 10632,00 & 1084,00 & 10,84 & 14,80 \\
10632,00 & 10840,00 & 1698,00 & 16,98 & 31,78 \\
10840,00 & 11048,00 & 1955,00 & 19,55 & 51,33 \\
11048,00 & 11256,00 & 1803,00 & 18,03 & 69,36 \\
11256,00 & 11464,00 & 1357,00 & 13,57 & 82,93 \\
11464,00 & 11672,00 & 930,00 & 9,30 & 92,23 \\
11672,00 & 11880,00 & 487,00 & 4,87 & 97,10 \\
11880,00 & 12088,00 & 218,00 & 2,18 & 99,28 \\
12088,00 & 12296,00 & 61,00 & 0,61 & 99,89 \\
12296,00 & 12504,00 & 11,00 & 0,11 & 100,00 \\
12504,00 & 12712,00 & 0,00 & 0,00 & 100,00 \\
12712,00 & 12920,00 & 0,00 & 0,00 & 100,00 \\
\hline Tota1 & & 10000,00 & 100,00 & \\
\hline
\end{tabular}

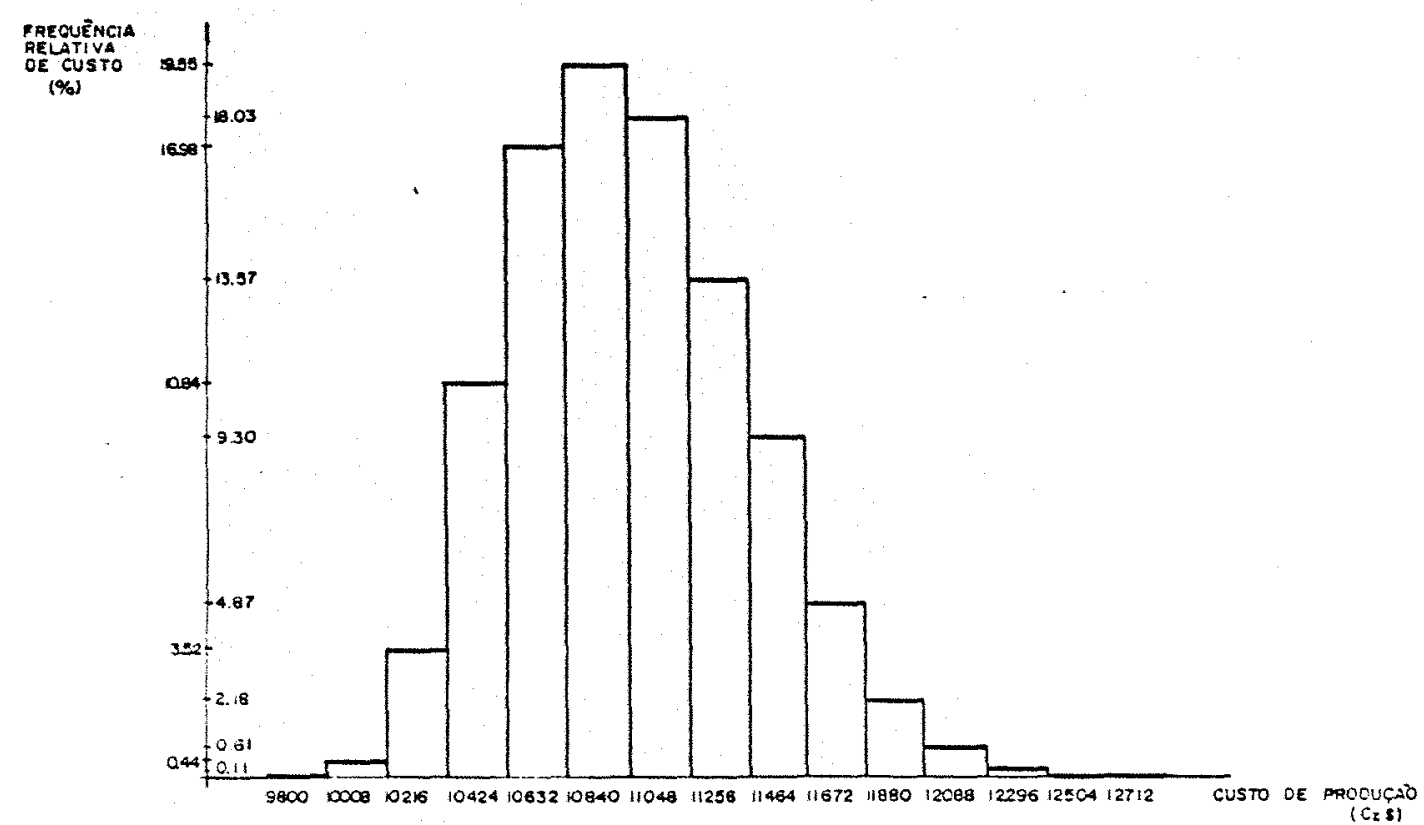

Histograma da distribuição de freqüēncia do custo para a cultura $C$. 
Tabela 4. Distribuição de freqüencias de custo, para a cultura cana-de-açücar, TM, 2: corte, DIRA Campinas (D).

\begin{tabular}{lcccr}
\hline $\begin{array}{c}\text { Limite } \\
\text { inferior }\end{array}$ & $\begin{array}{c}\text { Limite } \\
\text { superior }\end{array}$ & Freqüência & $\begin{array}{r}\text { Freqüencia } \\
\text { relativa }\end{array}$ & $\begin{array}{r}\text { Freqüência } \\
\text { relativa } \\
\text { acumulada }\end{array}$ \\
\hline 3400,00 & 3556,00 & 1,00 & 0,01 & 0,01 \\
3556,00 & 3712,00 & 45,00 & 0,45 & 0,46 \\
3712,00 & 3868,00 & 398,00 & 3,98 & 4,44 \\
3868,00 & 4024,00 & 1143,00 & 11,43 & 15,87 \\
4024,00 & 4180,00 & 1779,00 & 17,79 & 33,66 \\
4180,00 & 4336,00 & 1899,00 & 18,99 & 52,65 \\
4336,00 & 4492,00 & 1634,00 & 16,34 & 68,99 \\
4492,00 & 4648,00 & 1281,00 & 12,81 & 81,80 \\
4648,00 & 4804,00 & 886,00 & 8,86 & 90,66 \\
4804,00 & 4960,00 & 561,00 & 5,61 & 96,27 \\
4960,00 & 5116,00 & 274,00 & 2,74 & 99,01 \\
5116,00 & 5272,00 & 82,00 & 0,82 & 99,83 \\
5272,00 & 5428,00 & 17,00 & 0,17 & 100,00 \\
5428,00 & 5584,00 & 0,00 & 0,00 & 100,00 \\
5584,00 & 5740,00 & 0,00 & 0,00 & 100,00 \\
\hline Total & & 10000,00 & 100,00 & \\
\hline
\end{tabular}

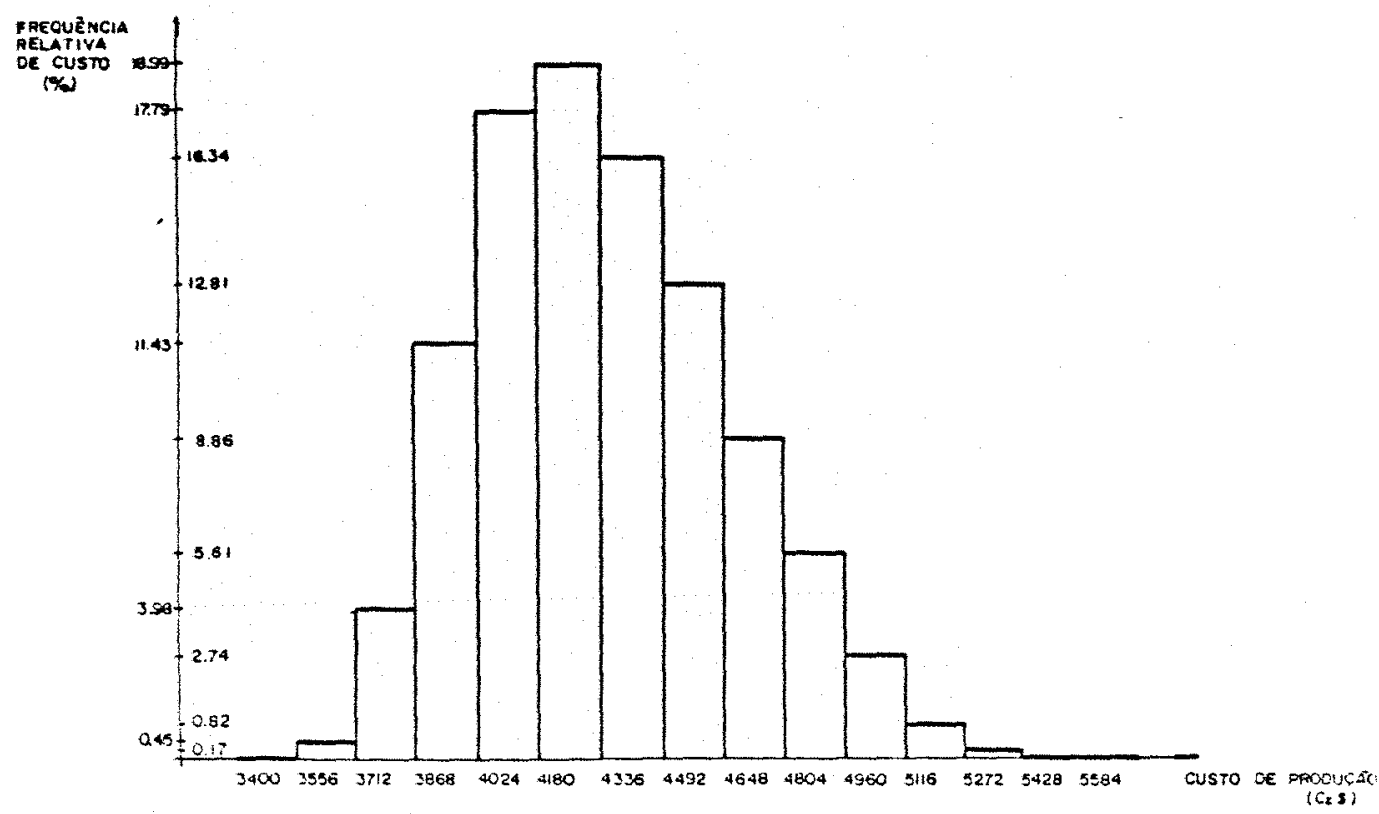

Histograma da distribuição de freqüencia do custo para a cultura 0 . 
Tabela 5. Distribuição de freqüências de custo, para a cultura cana-de-açücar, TM, 3: corte, DIRA Campinas (E)

\begin{tabular}{lrrrr}
\hline $\begin{array}{c}\text { Limite } \\
\text { inferior }\end{array}$ & $\begin{array}{c}\text { Limite } \\
\text { superior }\end{array}$ & Freqüencia & $\begin{array}{r}\text { Freqüencia } \\
\text { relativa }\end{array}$ & $\begin{array}{r}\text { Freqüencia } \\
\text { relativa } \\
\text { acumulada }\end{array}$ \\
\hline 3100,00 & 3260,00 & 0,00 & 0,00 & 0,00 \\
3260,00 & 3420,00 & 24,00 & 0,24 & 0,24 \\
3420,00 & 3580,00 & 305,00 & 3,05 & 3,29 \\
3580,00 & 3740,00 & 1043,00 & 10,43 & 13,72 \\
3740,00 & 3900,00 & 1780,00 & 17,80 & 31,52 \\
3900,00 & 4060,00 & 1978,00 & 19,78 & 51,30 \\
4060,00 & 4220,00 & 1704,00 & 17,04 & 68,34 \\
4220,00 & 4330,00 & 1271,00 & 12,71 & 81,05 \\
4380,00 & 4540,00 & 888,00 & 8,88 & 89,93 \\
4540,00 & 4700,00 & 613,00 & 6,13 & 96,06 \\
4700,00 & 4860,00 & 269,00 & 2,69 & 98,75 \\
4860,00 & 5020,00 & 105,00 & 1,05 & 99,80 \\
5020,00 & 5180,00 & 18,00 & 0,18 & 99,98 \\
5180,00 & 5340,00 & 2,00 & 0,02 & 100,00 \\
5340,00 & 5500,00 & 0,00 & 0,00 & 100,00 \\
\hline Total & & 10000,00 & 100,00 & \\
\hline
\end{tabular}

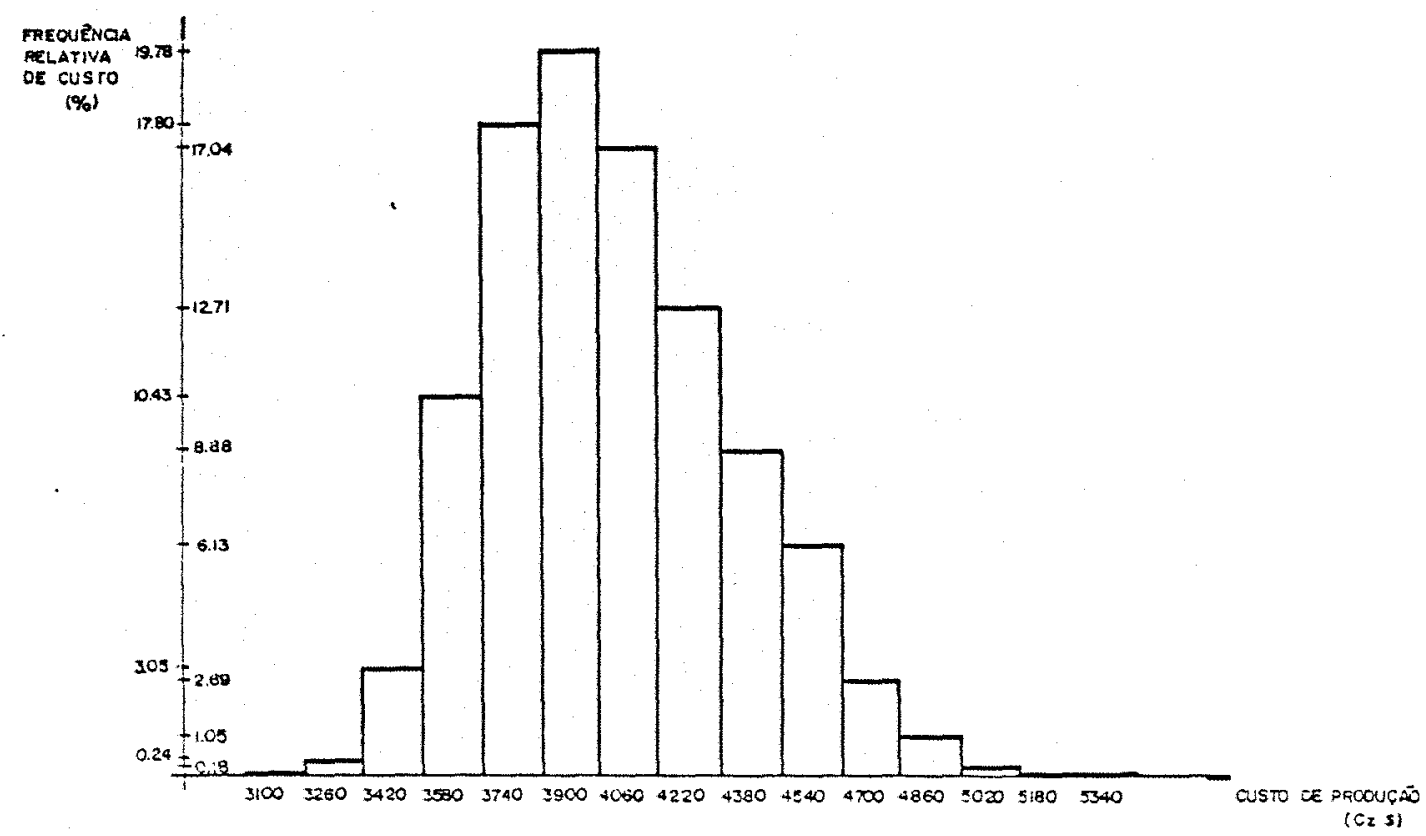

Histograma da distribuição de freqüencia do custo para a cultura E. 
Tabela 6. Distribuição de freqüências de custo, para a cultura cana-de-açücar, plantio, DIRA Ribeirão Preto (F).

\begin{tabular}{lcrrr}
\hline $\begin{array}{c}\text { Limite } \\
\text { inferior }\end{array}$ & $\begin{array}{c}\text { Limite } \\
\text { superior }\end{array}$ & Freqüência & $\begin{array}{r}\text { Freqüencia } \\
\text { relativa }\end{array}$ & $\begin{array}{r}\text { Freqüencia } \\
\text { relativa } \\
\text { acumulada }\end{array}$ \\
\hline 9500,00 & 9600,00 & 0,00 & 0,00 & 0,00 \\
9600,00 & 9700,00 & 13,00 & 0,13 & 0,13 \\
9700,00 & 9800,00 & 116,00 & 1,16 & 1,29 \\
9800,00 & 9900,00 & 272,00 & 2,72 & 4,01 \\
9900,00 & 10000,00 & 548,00 & 5,48 & 9,49 \\
10000,00 & 10100,00 & 895,00 & 8,95 & 18,44 \\
10100,00 & 10200,00 & 1213,00 & 12,13 & 30,57 \\
10200,00 & 10300,00 & 1606,00 & 16,06 & 46,63 \\
10300,00 & 10400,00 & 1728,00 & 17,28 & 63,91 \\
10400,00 & 10500,00 & 1445,00 & 14,45 & 78,36 \\
10500,00 & 10600,00 & 1057,00 & 10,57 & 88,93 \\
10600,00 & 10700,00 & 617,00 & 6,17 & 95,10 \\
10700,00 & 10800,00 & 344,00 & 3,44 & 98,54 \\
10800,00 & 10900,00 & 121,00 & 1,21 & 99,75 \\
10900,00 & 11000,00 & 25,00 & 0,25 & 100,00 \\
\hline Total & & 10000,00 & 100,00 & \\
\hline
\end{tabular}

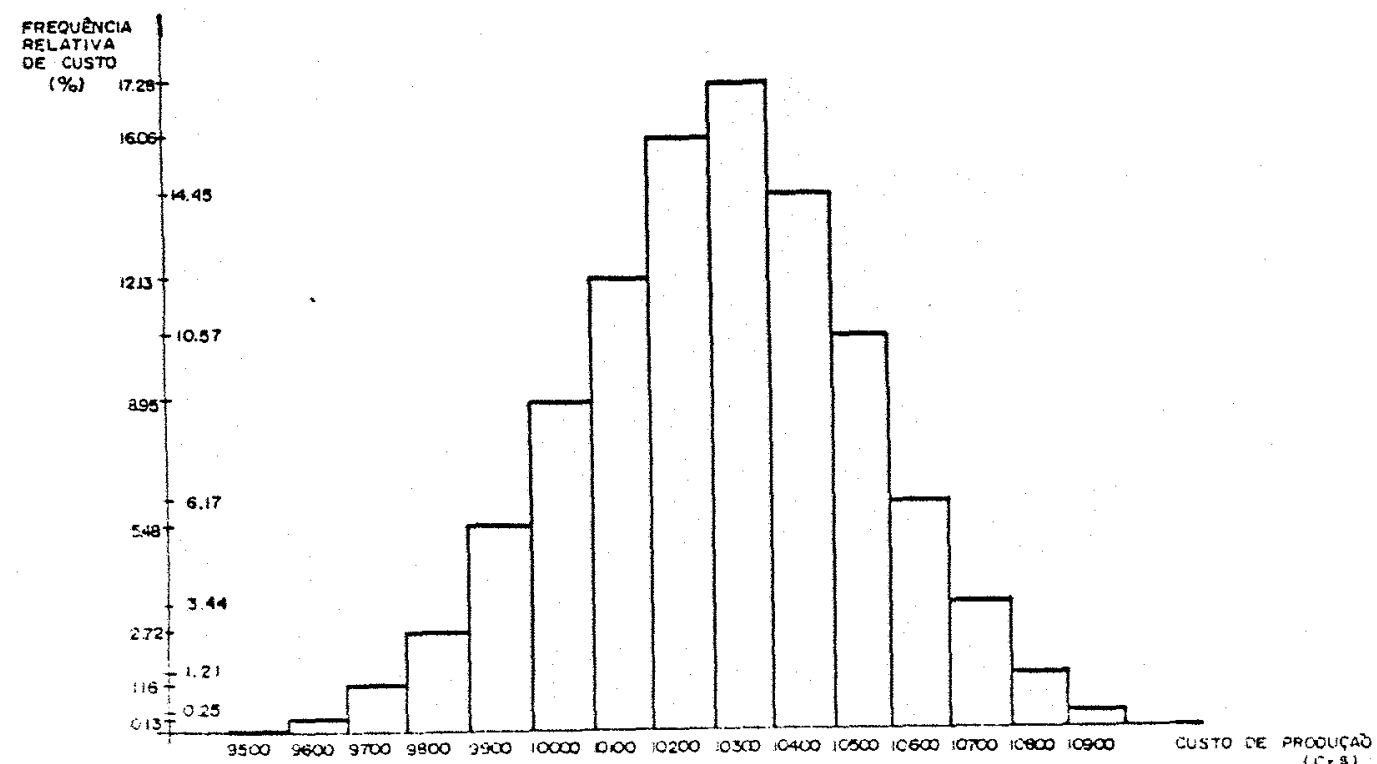

Histograma da distribuição de freqüencia do custo para a cultura F. 
Tabela 7. Distribuição de freqüência de custos, para a cultura cana-de-açúcar, TM, 2: corte, DIRA Ribeirão Preto (G).

\begin{tabular}{lcrrr}
\hline $\begin{array}{c}\text { Limite } \\
\text { inferior }\end{array}$ & $\begin{array}{c}\text { Limite } \\
\text { superior }\end{array}$ & Freqüência & $\begin{array}{c}\text { Freqüencia } \\
\text { relativa }\end{array}$ & $\begin{array}{r}\text { Freqüencia } \\
\text { relativa } \\
\text { acumulada }\end{array}$ \\
\hline 3900,00 & 3960,00 & 15,00 & 0,15 & 0,15 \\
3960,00 & 4020,00 & 119,00 & 1,19 & 1,34 \\
4020,00 & 4080,00 & 372,00 & 3,72 & 5,06 \\
4080,00 & 4140,00 & 750,00 & 7,50 & 12,56 \\
4140,00 & 4200,00 & 1184,00 & 11,84 & 24,40 \\
4200,00 & 4260,00 & 1645,00 & 16,45 & 40,85 \\
4260,00 & 4320,00 & 1563,00 & 15,63 & 56,48 \\
4320,00 & 4380,00 & 1333,00 & 13,33 & 69,81 \\
4380,00 & 4440,00 & 1111,00 & 11,11 & 80,92 \\
4440,00 & 4500,00 & 832,00 & 8,32 & 89,24 \\
4500,00 & 4560,00 & 547,00 & 5,47 & 94,71 \\
4560,00 & 4620,00 & 342,00 & 3,42 & 98,13 \\
4620,00 & 4680,00 & 136,00 & 1,36 & 99,49 \\
4680,00 & 4740,00 & 50,00 & 0,50 & 99,99 \\
4740,00 & 4800,00 & 1,00 & 0,01 & 100,00 \\
\hline Total & \multicolumn{4}{c}{} \\
\hline
\end{tabular}

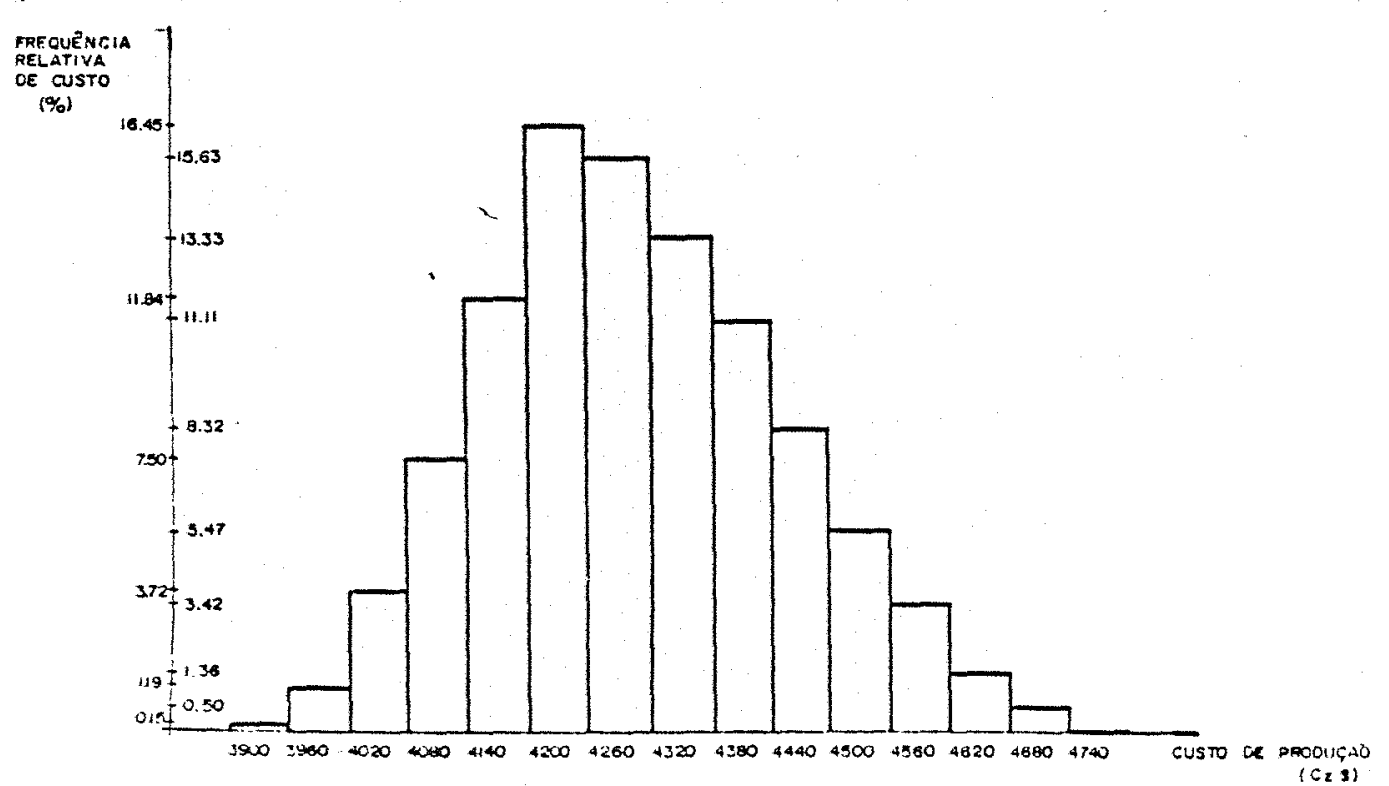

Histograma da distribuição de freqüencia do custo para a cultura G. 
Tabela 8. Distribuição de freqüēncia de custos, para a cultura cana-de-açúcar, TM, 3: corte, DIRA Ribeiräo Preto (H).

\begin{tabular}{lcrrr}
\hline $\begin{array}{c}\text { Limite } \\
\text { inferior }\end{array}$ & $\begin{array}{c}\text { Limite } \\
\text { superior }\end{array}$ & Freqüencia & $\begin{array}{r}\text { Freqüencia } \\
\text { relativa }\end{array}$ & $\begin{array}{r}\text { Freqüencia } \\
\text { relativa } \\
\text { acumulada }\end{array}$ \\
\hline 3600,00 & 3660,00 & 0,00 & 0,00 & 0,00 \\
3660,00 & 3720,00 & 38,00 & 0,38 & 0,38 \\
3720,00 & 3780,00 & 295,00 & 2,95 & 3,33 \\
3780,00 & 3840,00 & 900,00 & 9,00 & 12,33 \\
3840,00 & 3900,00 & 1622,00 & 16,22 & 28,55 \\
3900,00 & 3960,00 & 1751,00 & 17,51 & 46,06 \\
3960,00 & 4020,00 & 1592,00 & 15,92 & 61,98 \\
4020,00 & 4080,00 & 1216,00 & 12,16 & 74,14 \\
4080,00 & 4140,00 & 1047,00 & 10,47 & 84,61 \\
4140,00 & 4200,00 & 731,00 & 7,31 & 91,92 \\
4200,00 & 4260,00 & 486,00 & 4,86 & 96,78 \\
4260,00 & 4320,00 & 234,00 & 2,34 & 99,12 \\
4320,00 & 4380,00 & 81,00 & 0,81 & 99,93 \\
4380,00 & 4440,00 & 7,00 & 0,07 & 100,00 \\
4400,00 & 4500,00 & 0,00 & 0,00 & 100,00 \\
\hline Total & & 10000,00 & 100,00 & \\
\hline
\end{tabular}

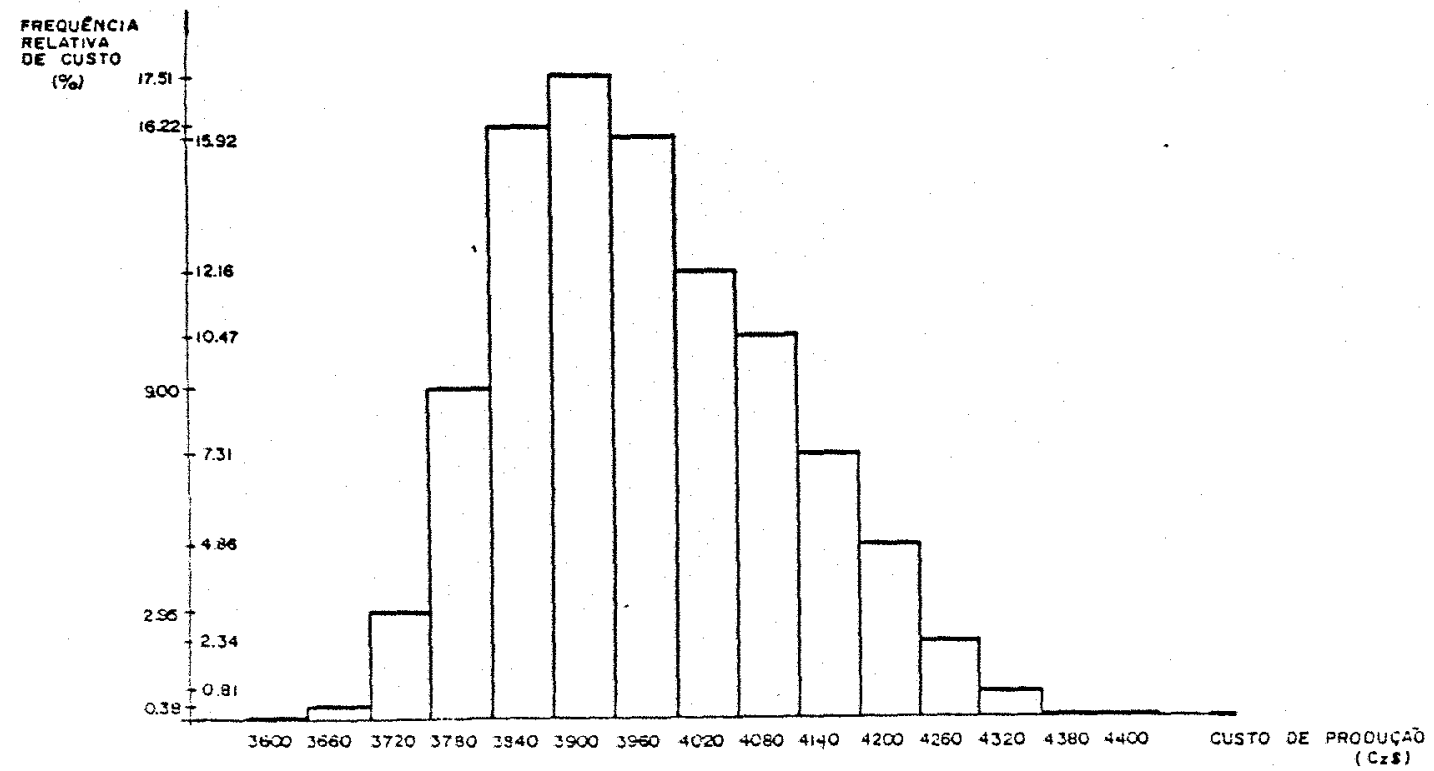

Histograma da distribuição de freqüència do custo para a cultura H. 
Tabela 9. Distribuição de freqüēncia de custos, para a cultura feijão das äguas, TA, DIRA Sorocaba (1).

\begin{tabular}{lcrrr}
\hline $\begin{array}{c}\text { Limite } \\
\text { inferior }\end{array}$ & $\begin{array}{c}\text { Limite } \\
\text { superior }\end{array}$ & Freqüencia & $\begin{array}{r}\text { Freqüencia } \\
\text { relativa }\end{array}$ & $\begin{array}{r}\text { Freqüencia } \\
\text { relativa } \\
\text { acumulada }\end{array}$ \\
\hline 1300,00 & 1380,00 & 0,00 & 0,00 & 0,00 \\
1380,00 & 1460,00 & 0,00 & 0,00 & 0,00 \\
1460,00 & 1540,00 & 0,00 & 0,00 & 0,00 \\
1540,00 & 1620,00 & 249,00 & 2,49 & 2,49 \\
1620,00 & 1700,00 & 1467,00 & 14,67 & 17,16 \\
1700,00 & 1780,00 & 1959,00 & 19,59 & 36,75 \\
1780,00 & 1860,00 & 1763,00 & 17,63 & 54,38 \\
1860,00 & 1940,00 & 1489,00 & 14,89 & 69,27 \\
1940,00 & 2020,00 & 1171,00 & 11,71 & 80,98 \\
2020,00 & 2100,00 & 887,00 & 8,87 & 89,85 \\
2100,00 & 2180,00 & 606,00 & 6,06 & 95,91 \\
2180,00 & 2260,00 & 316,00 & 3,16 & 99,07 \\
2260,00 & 2340,00 & 89,00 & 0,89 & 99,96 \\
2340,00 & 2420,00 & 4,00 & 0,04 & 100,00 \\
2420,00 & 2500,00 & 0,00 & 0,00 & 100,00 \\
\hline Total & \multicolumn{5}{c}{00000} \\
\hline
\end{tabular}

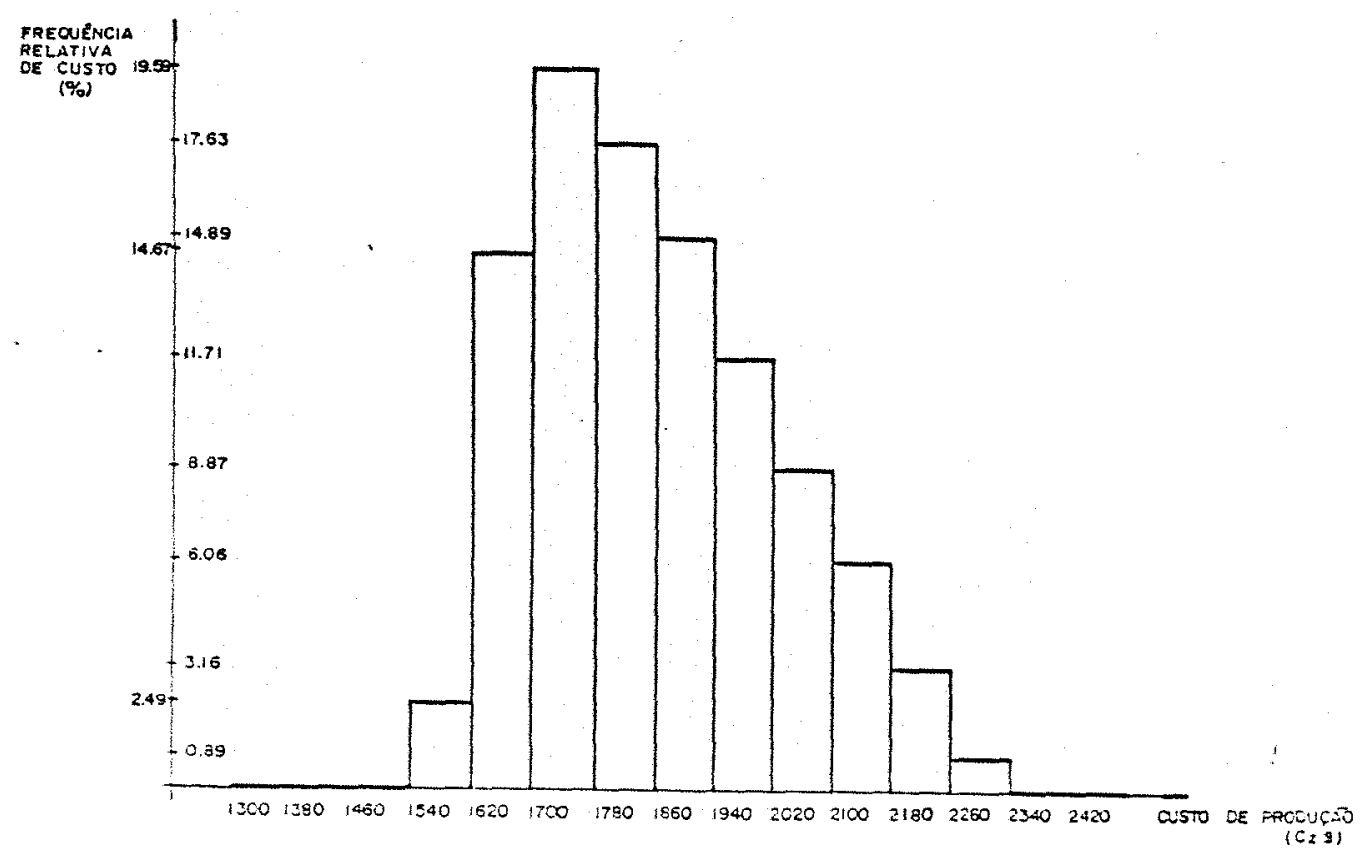

Histograma da distribuição de freqüancia do custo para a cultura 1. 
Tabela 10. Distribuição de freqüēncias de custo, para a cultura feijão das äguas, TMA, OIRA Sorocaba (J).

\begin{tabular}{lcccc}
\hline $\begin{array}{c}\text { Limite } \\
\text { inferior }\end{array}$ & $\begin{array}{c}\text { Limite } \\
\text { superior }\end{array}$ & Freqüencia & $\begin{array}{c}\text { Freqüencia } \\
\text { relativa }\end{array}$ & $\begin{array}{r}\text { Freqüencia } \\
\text { relativa } \\
\text { acumulada }\end{array}$ \\
\hline 2900,00 & 2980,00 & 0,00 & 0,00 & 0,00 \\
2980,00 & 3060,00 & 5,00 & 0,05 & 0,05 \\
3060,00 & 3140,00 & 86,00 & 0,86 & 0,91 \\
3140,00 & 3220,00 & 449,00 & 4,49 & 5,40 \\
3220,00 & 3300,00 & 1132,00 & 11,32 & 16,72 \\
3300,00 & 3380,00 & 1832,00 & 18,32 & 35,04 \\
3380,00 & 3460,00 & 2170,00 & 21,70 & 56,74 \\
3460,00 & 3540,00 & 1864,00 & 18,64 & 75,33 \\
3540,00 & 3620,00 & 1330,00 & 13,30 & 88,68 \\
3620,00 & 3700,00 & 720,00 & 7,20 & 95,88 \\
3700,00 & 3780,00 & 322,00 & 3,22 & 99,10 \\
3780,00 & 3860,00 & 72,00 & 0,72 & 99,82 \\
3860,00 & 3940,00 & 18,00 & 0,18 & 100,00 \\
3940,00 & 4020,00 & 0,00 & 0,00 & 100,00 \\
4020,00 & 4100,00 & 0,00 & 0,00 & 100,00 \\
\hline Total & & 10000,00 & 100,00 & \\
\hline
\end{tabular}

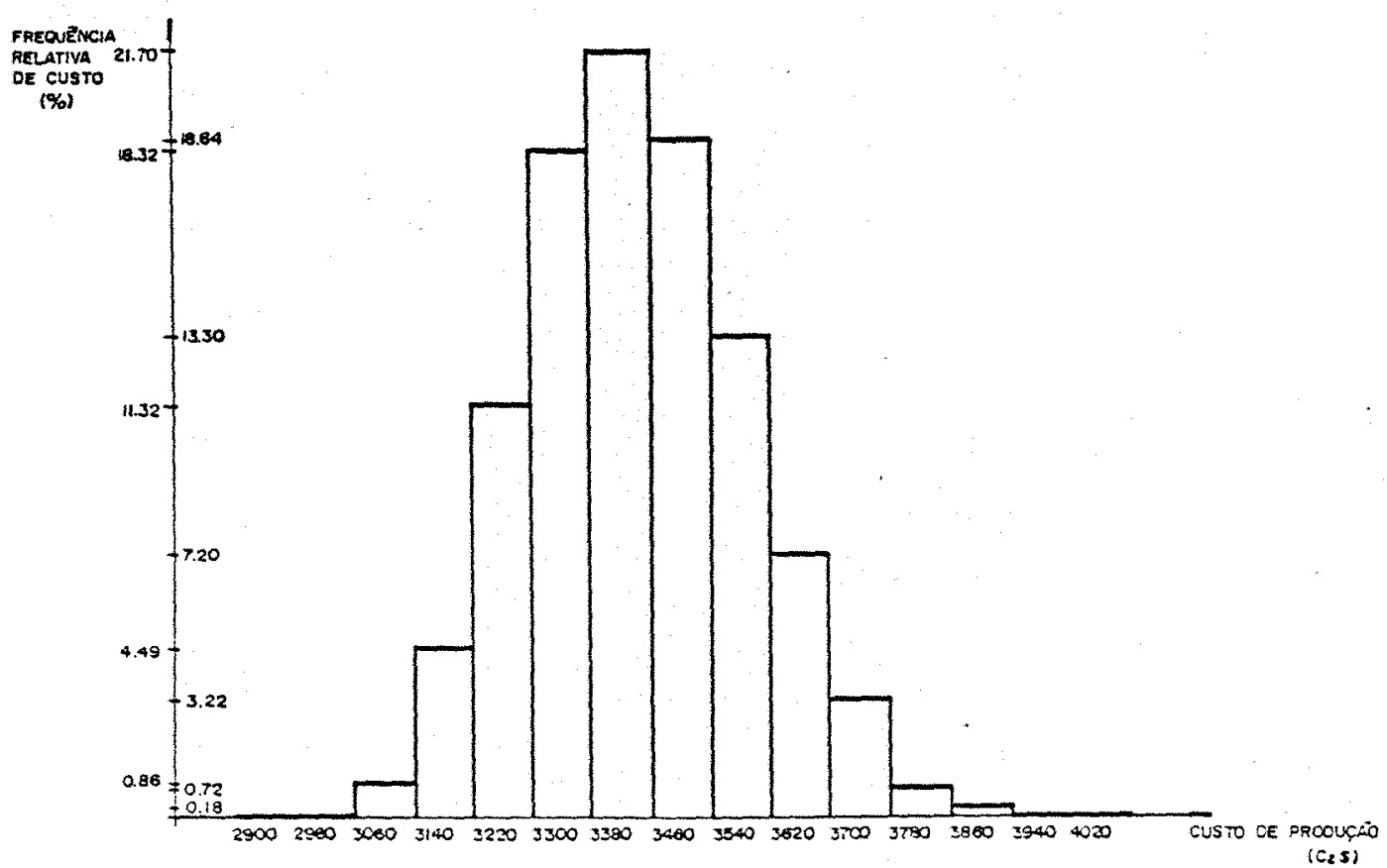

Histograma da distribuição de frequêencia do custo para a cultura J. 
Tabela 11. Distribuição de freqüencias de custo, para a cultura miIho, TMA, sub-regiäo Avarë $(K)$.

\begin{tabular}{ccccc}
\hline $\begin{array}{c}\text { Limite } \\
\text { inferior }\end{array}$ & $\begin{array}{c}\text { Limite } \\
\text { superior }\end{array}$ & Freqüência & $\begin{array}{r}\text { Freqüencia } \\
\text { relativa }\end{array}$ & $\begin{array}{r}\text { Freqüencia } \\
\text { relativa } \\
\text { acumulada }\end{array}$ \\
\hline 2000,00 & 2070,00 & 0,00 & 0,00 & 0,00 \\
2070,00 & 2140,00 & 39,00 & 0,39 & 0,39 \\
2140,00 & 2210,00 & 575,00 & 5,75 & 6,14 \\
2210,00 & 2280,00 & 1439,00 & 14,39 & 20,53 \\
2280,00 & 2350,00 & 1900,00 & 19,00 & 39,53 \\
2350,00 & 2420,00 & 1950,00 & 19,50 & 59,03 \\
2420,00 & 2490,00 & 1689,00 & 16,89 & 75,92 \\
2490,00 & 2560,00 & 1198,00 & 11,98 & 87,90 \\
2560,00 & 2630,00 & 717,00 & 7,17 & 95,07 \\
2630,00 & 2700,00 & 351,00 & 3,51 & 98,58 \\
2700,00 & 2770,00 & 104,00 & 1,04 & 99,62 \\
2770,00 & 2840,00 & 34,00 & 0,34 & 99,96 \\
2840,00 & 2910,00 & 4,00 & 0,04 & 100,00 \\
2910,00 & 2980,00 & 0,00 & 0,00 & 100,00 \\
2980,00 & 3050,00 & 0,00 & 0,00 & 100,00 \\
\hline Tota1 & & 10000,00 & 100,00 & \\
\hline
\end{tabular}

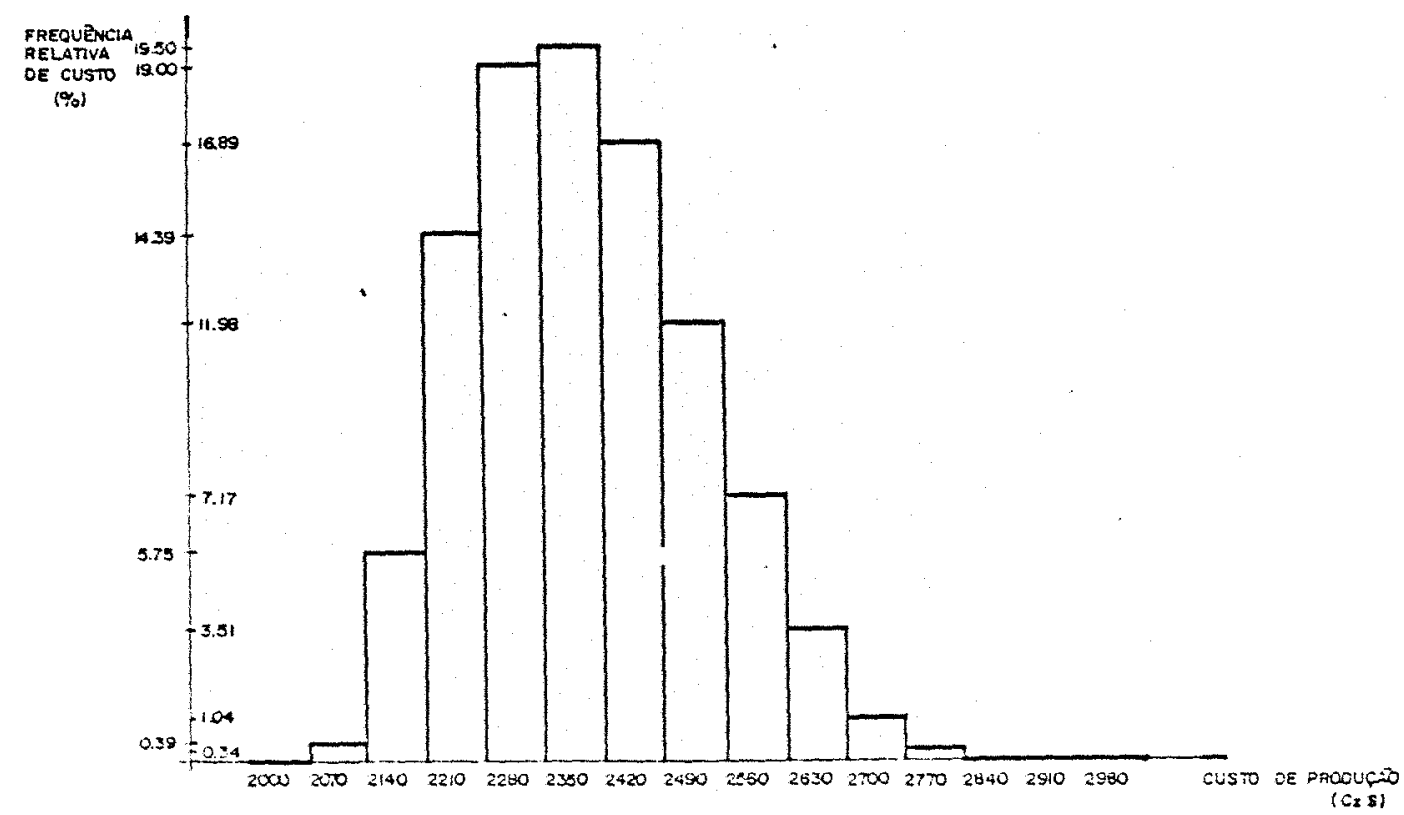

Histograma da distribuição de freqüencias de custo para a cultura K. 
Tabela 12. Distribuição de freqüências de custo, para a cultura miIho, TM, sub-região Avarè (L).

\begin{tabular}{lccrr}
\hline $\begin{array}{c}\text { Limite } \\
\text { inferior }\end{array}$ & $\begin{array}{c}\text { Limite } \\
\text { superior }\end{array}$ & Freqüência & $\begin{array}{r}\text { Freqüencia } \\
\text { relativa }\end{array}$ & $\begin{array}{r}\text { Freqüencia } \\
\text { relativa } \\
\text { acumulada }\end{array}$ \\
\hline 1950,00 & 2026,00 & 0,00 & 0,00 & 0,00 \\
2026,00 & 2102,00 & 98,00 & 0,98 & 0,98 \\
2102,00 & 2178,00 & 765,00 & 7,65 & 8,63 \\
2178,00 & 2254,00 & 1328,00 & 13,28 & 21,91 \\
2254,00 & 2330,00 & 1664,00 & 16,64 & 38,55 \\
2330,00 & 2406,00 & 1736,00 & 17,36 & 55,91 \\
2406,00 & 2482,00 & 1547,00 & 15,47 & 71,38 \\
2482,00 & 2558,00 & 1158,00 & 11,58 & 82,96 \\
2558,00 & 2634,00 & 851,00 & 8,51 & 91,47 \\
2634,00 & 2710,00 & 485,00 & 4,85 & 96,32 \\
2710,00 & 2786,00 & 224,00 & 2,24 & 98,56 \\
2786,00 & 2862,00 & 111,00 & 1,11 & 99,67 \\
2862,00 & 2938,00 & 29,00 & 0,29 & 99,96 \\
2938,00 & 3014,00 & 40,00 & 0,04 & 100,00 \\
3014,00 & 3090,00 & 0,00 & 0,00 & 100,00 \\
\hline Tota1 & & 10000,00 & 100,00 & \\
\hline
\end{tabular}

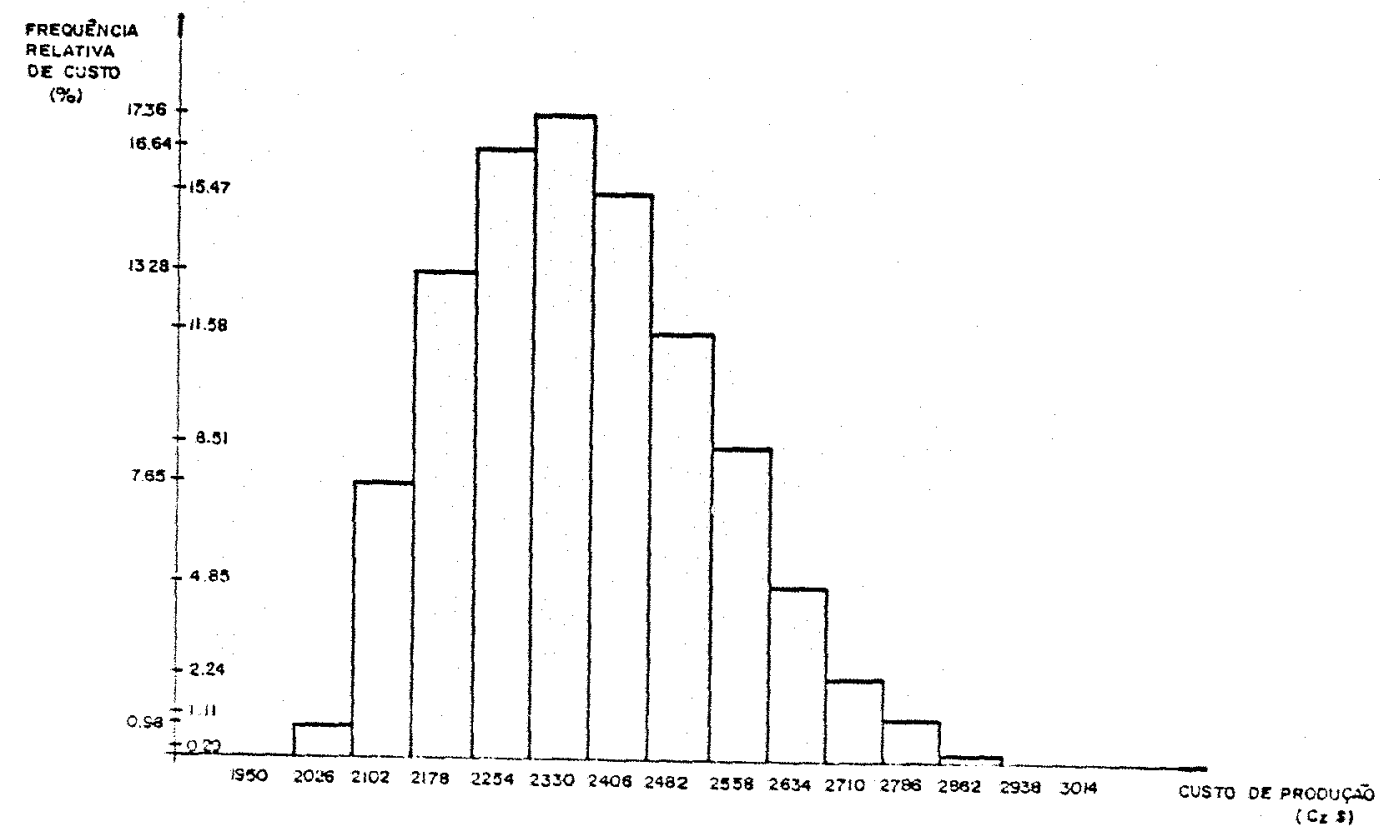

Histograma da distribuição de freqüencias de custo para a cultura L. 
Tabela 13. Distribuição de freqüēncia do custo, para a cultura milho, TM, oIRA Ribeirão Preto $(M)$.

\begin{tabular}{lcrrr}
\hline $\begin{array}{c}\text { Limite } \\
\text { inferior }\end{array}$ & $\begin{array}{c}\text { Limite } \\
\text { superior }\end{array}$ & Freqüencia & $\begin{array}{r}\text { Freqüencia } \\
\text { relativa }\end{array}$ & $\begin{array}{r}\text { Freqüencia } \\
\text { relativa } \\
\text { acumulada }\end{array}$ \\
\hline 2300,00 & 2390,00 & 4,00 & 0,04 & 0,04 \\
2390,00 & 2480,00 & 202,00 & 2,02 & 2,06 \\
2480,00 & 2570,00 & 863,00 & 8,63 & 10,69 \\
2570,00 & 2660,00 & 1427,00 & 14,27 & 24,96 \\
2660,00 & 2750,00 & 1705,00 & 17,05 & 42,01 \\
2750,00 & 2840,00 & 1612,00 & 16,12 & 58,13 \\
2840,00 & 2930,00 & 1424,00 & 14,24 & 72,37 \\
2930,00 & 3020,00 & 1119,00 & 11,19 & 83,56 \\
3020,00 & 3110,00 & 793,00 & 7,93 & 91,49 \\
3110,00 & 3200,00 & 466,00 & 4,66 & 96,15 \\
3200,00 & 3290,00 & 263,00 & 2,63 & 98,78 \\
3290,00 & 3380,00 & 87,00 & 0,87 & 99,65 \\
3380,00 & 3470,00 & 33,00 & 0,33 & 99,98 \\
3470,00 & 3560,00 & 2,00 & 0,02 & 100,00 \\
3560,00 & 3650,00 & 0,00 & 0,00 & 100,00 \\
\hline Total & & 10000,00 & 100,00 & \\
\hline
\end{tabular}

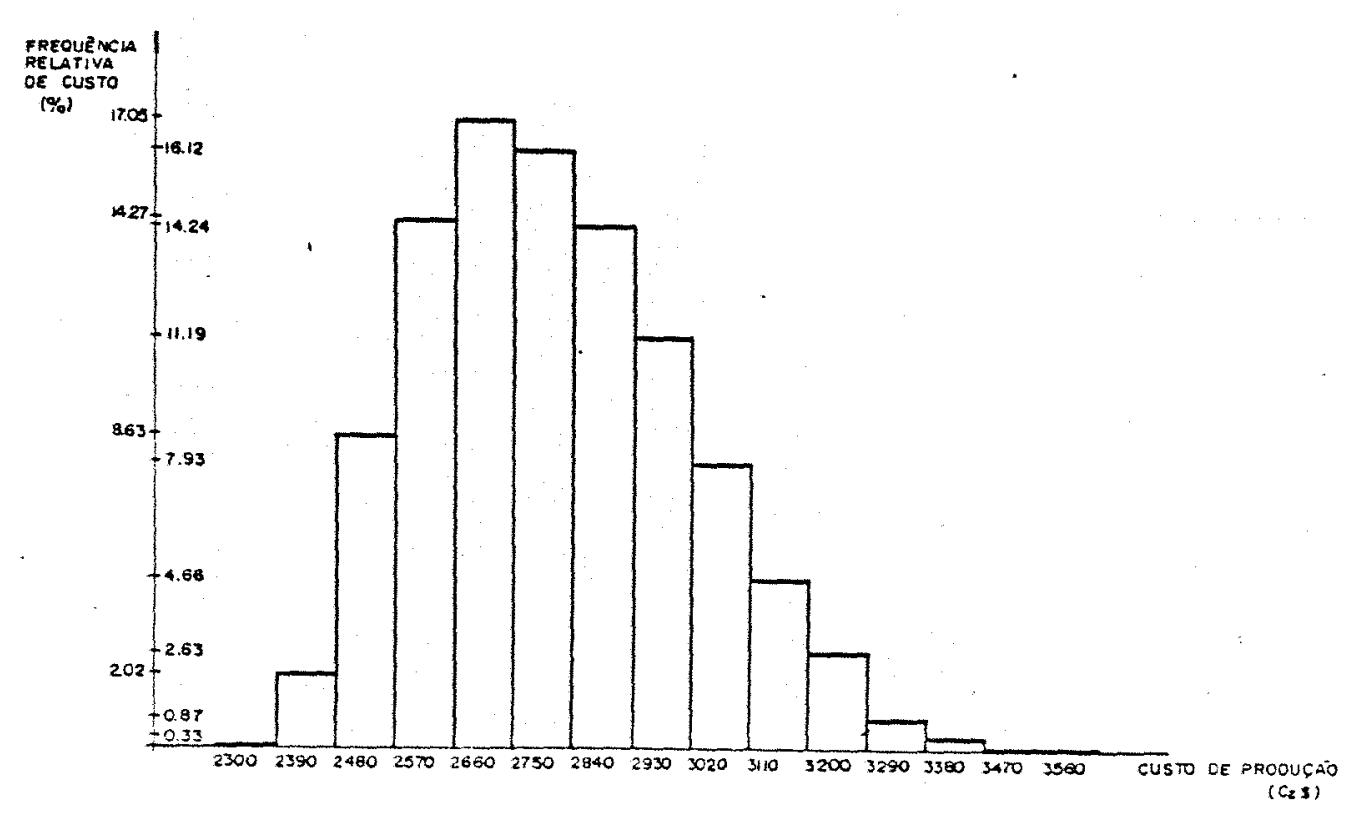

Histograma da distribuição de freqüencias de custo para a cultura M. 
Tabela 14. Distribuição de freqüencias de custo, para a cultura feijão da seca, TMA, DIRA Sorocaba (N).

\begin{tabular}{lcrrr}
\hline $\begin{array}{c}\text { Limite } \\
\text { inferior }\end{array}$ & $\begin{array}{c}\text { Limite } \\
\text { superior }\end{array}$ & Freqüencia & $\begin{array}{c}\text { Freqüencia } \\
\text { relativa }\end{array}$ & $\begin{array}{r}\text { Freqüência } \\
\text { relativa } \\
\text { acumulada }\end{array}$ \\
\hline 2200,00 & 2276,00 & 0,00 & 0,00 & 0,00 \\
2276,00 & 2352,00 & 5,00 & 0,05 & 0,05 \\
2352,00 & 2428,00 & 182,00 & 1,82 & 1,87 \\
2428,00 & 2504,00 & 818,00 & 8,18 & 10,05 \\
2504,00 & 2580,00 & 1606,00 & 16,06 & 26,11 \\
2580,00 & 2656,00 & 2017,00 & 20,17 & 46,28 \\
2656,00 & 2732,00 & 1854,00 & 18,54 & 64,82 \\
2732,00 & 2808,00 & 1461,00 & 14,61 & 79,43 \\
2808,00 & 2884,00 & 1042,00 & 10,42 & 89,85 \\
2884,00 & 2960,00 & 655,00 & 6,55 & 96,40 \\
2960,00 & 3036,00 & 275,00 & 2,75 & 99,15 \\
3036,00 & 3112,00 & 72,00 & 0,72 & 99,87 \\
3112,00 & 3188,00 & 13,00 & 0,13 & 100,00 \\
3188,00 & 3264,00 & 0,00 & 0,00 & 100,00 \\
3264,00 & 3340,00 & 0,00 & 0,00 & 100,00 \\
\hline Tota1 & & 10000,00 & 100,00 & \\
\hline
\end{tabular}

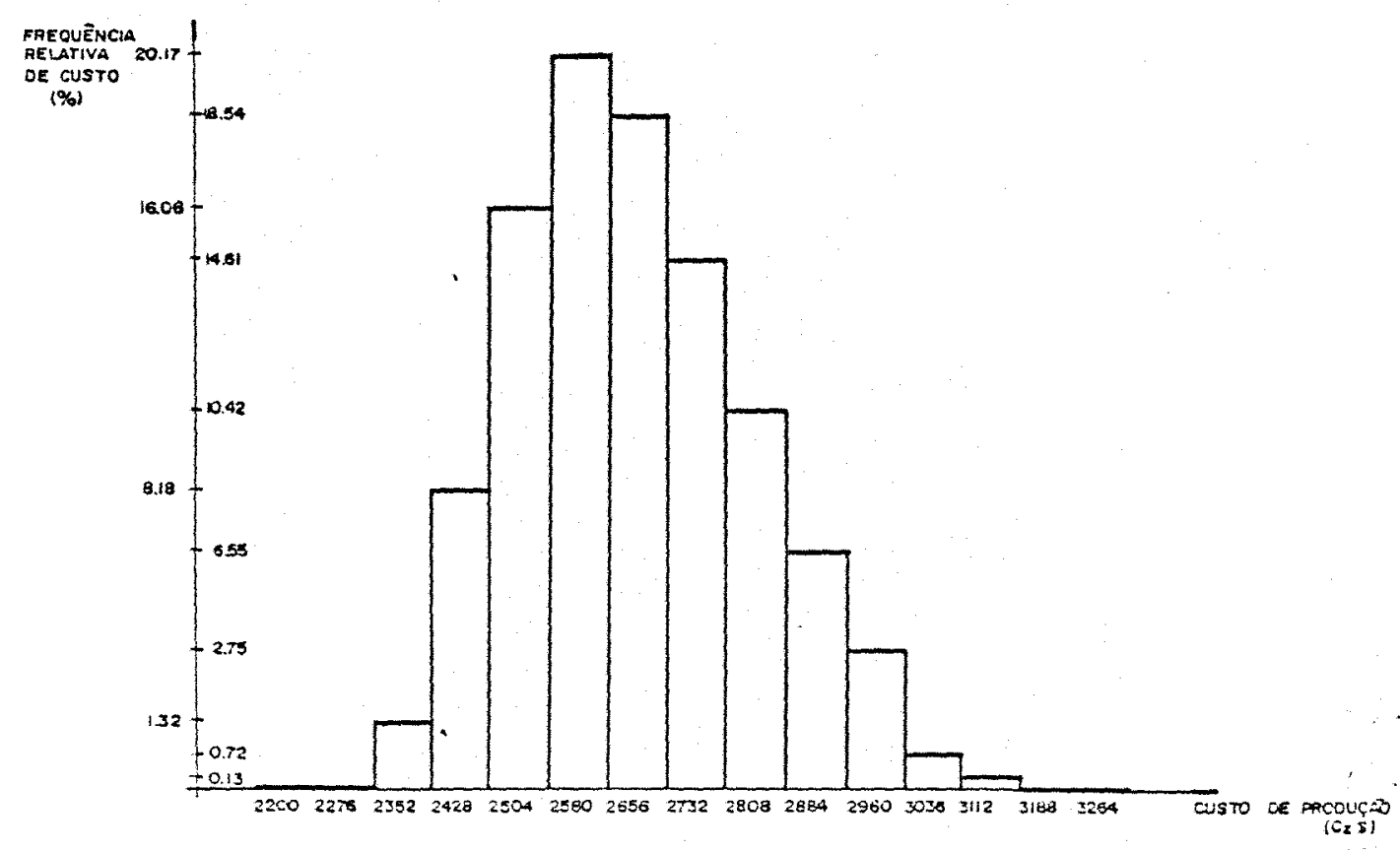

Histograma da distribulção de freqüencias do custo para a cultura $N$. 
Tabela 15. Distribuição de freqüëncias de custo, para a cultura feijão da seca, TM, DIRA Sorocaba (0).

\begin{tabular}{lcrrr}
\hline $\begin{array}{c}\text { Limite } \\
\text { inferior }\end{array}$ & $\begin{array}{c}\text { Limite } \\
\text { superior }\end{array}$ & Freqüencia & $\begin{array}{r}\text { Freqüencia } \\
\text { relativa }\end{array}$ & $\begin{array}{r}\text { Freqüéncia } \\
\text { relativa } \\
\text { acumulada }\end{array}$ \\
\hline 2900,00 & 2985,00 & 0,00 & 0,00 & 0,00 \\
2985,00 & 3070,00 & 4,00 & 0,04 & 0,04 \\
3070,00 & 3155,00 & 53,00 & 0,53 & 0,57 \\
3155,00 & 3240,00 & 448,00 & 4,48 & 5,05 \\
3240,00 & 3325,00 & 1214,00 & 12,14 & 17,19 \\
3325,00 & 3410,00 & 2014,00 & 20,14 & 37,33 \\
3410,00 & 3495,00 & 2250,00 & 22,50 & 59,83 \\
3495,00 & 3580,00 & 1817,00 & 18,17 & 78,00 \\
3580,00 & 3665,00 & 1244,00 & 12,44 & 90,44 \\
3665,00 & 3750,00 & 635,00 & 6,35 & 96,79 \\
3750,00 & 3835,00 & 260,00 & 2,60 & 99,39 \\
3835,00 & 3920,00 & 52,00 & 0,52 & 99,91 \\
3920,00 & 4005,00 & 8,00 & 0,08 & 99,99 \\
4005,00 & 4090,00 & 1,00 & 0,01 & 100,00 \\
4090,00 & 4175,00 & 0,00 & 0,00 & 100,00 \\
\hline Total & & 10000,00 & 100,00 & \\
\hline
\end{tabular}

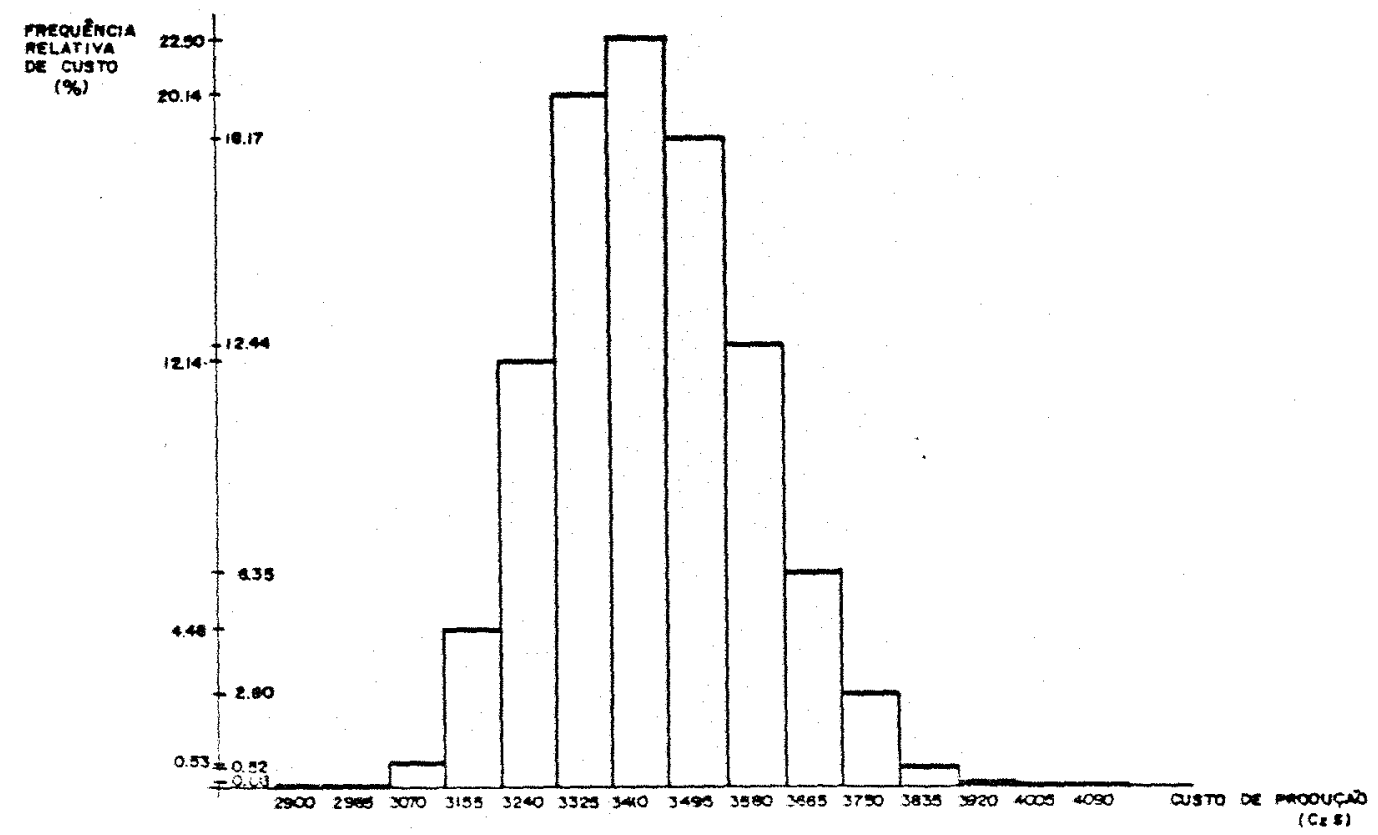

Histograma da distribuição de freqüencia do custo para a cultura 0. 
Tabela 16. Distribuição de freqüências de custo, para a cultura feijão de inverno irrigado, TM, DIRA São Josē do Rio Preto(P).

\begin{tabular}{ccccc}
\hline $\begin{array}{c}\text { Limite } \\
\text { inferior }\end{array}$ & $\begin{array}{c}\text { Limite } \\
\text { superior }\end{array}$ & Freqüencia & $\begin{array}{r}\text { Freqüencia } \\
\text { relativa }\end{array}$ & $\begin{array}{r}\text { Freqüencia } \\
\text { relativa } \\
\text { acumulada }\end{array}$ \\
\hline 7150,00 & 7390,00 & 0,00 & 0,00 & 0,00 \\
7390,00 & 7630,00 & 1,00 & 0,01 & 0,01 \\
7630,00 & 7870,00 & 66,00 & 0,66 & 0,67 \\
7870,00 & 8110,00 & 409,00 & 4,09 & 4,76 \\
8110,00 & 8350,00 & 1172,00 & 11,72 & 16,48 \\
8350,00 & 8590,00 & 2013,00 & 20,13 & 36,61 \\
8590,00 & 8830,00 & 2333,00 & 23,33 & 59,94 \\
8830,00 & 9070,00 & 1922,00 & 19,22 & 79,16 \\
9070,00 & 9310,00 & 1225,00 & 12,25 & 91,41 \\
9310,00 & 9550,00 & 617,00 & 6,17 & 97,58 \\
9550,00 & 9790,00 & 198,00 & 1,98 & 99,56 \\
9790,00 & 10030,00 & 42,00 & 0,42 & 99,98 \\
10030,00 & 10270,00 & 2,00 & 0,02 & 100,00 \\
10270,00 & 10510,00 & 0,00 & 0,00 & 100,00 \\
10510,00 & 10750,00 & 0,00 & 0,00 & 100,00 \\
\hline Total & & 10000,00 & 100,00 & \\
\hline
\end{tabular}

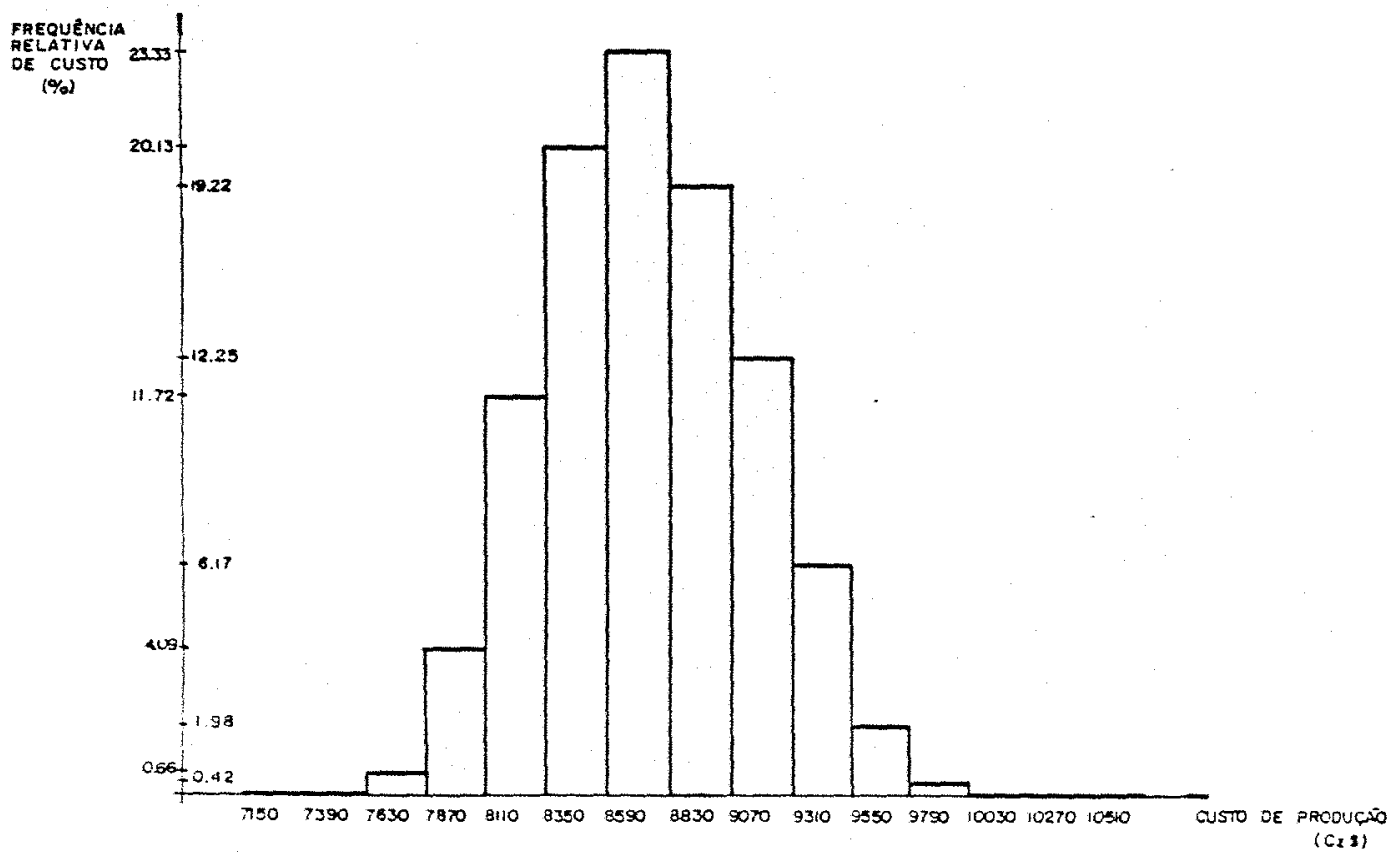

Histograma da distribuição de freqüencias de custo para a cultura P. 
Tabela 17. Distribuição de freqüèncias do custo, para a cultura trigo, $T M$, sub-região Assis ( $Q$ ).

\begin{tabular}{lcrrr}
\hline $\begin{array}{c}\text { Limite } \\
\text { inferior }\end{array}$ & $\begin{array}{c}\text { Limite } \\
\text { superior }\end{array}$ & Freqüencia & $\begin{array}{c}\text { Freqüencia } \\
\text { relativa }\end{array}$ & $\begin{array}{r}\text { Freqüencia } \\
\text { relativa } \\
\text { acumulada }\end{array}$ \\
\hline 3930,00 & 3990,00 & 253,00 & 2,53 & 2,53 \\
3990,00 & 4050,00 & 889,00 & 8,89 & 11,42 \\
4050,00 & 4110,00 & 1284,00 & 12,84 & 24,26 \\
4110,00 & 4170,00 & 1484,00 & 14,84 & 39,10 \\
4170,00 & 4230,00 & 1462,00 & 14,62 & 53,72 \\
4230,00 & 4290,00 & 1294,00 & 12,94 & 66,66 \\
4290,00 & 4350,00 & 1172,00 & 11,72 & 78,38 \\
4350,00 & 4410,00 & 873,00 & 8,73 & 87,11 \\
4410,00 & 4470,00 & 620,00 & 6,20 & 93,31 \\
4470,00 & 4530,00 & 368,00 & 3,68 & 96,99 \\
4530,00 & 4590,00 & 180,00 & 1,80 & 98,79 \\
4590,00 & 4650,00 & 78,00 & 0,78 & 99,57 \\
4650,00 & 4710,00 & 33,00 & 0,33 & 99,90 \\
4710,00 & 4770,00 & 10,00 & 0,10 & 100,00 \\
4770,00 & 4830,00 & 0,00 & 0,00 & 100,00 \\
\hline Total & & 10000,00 & 100,00 & \\
\hline
\end{tabular}

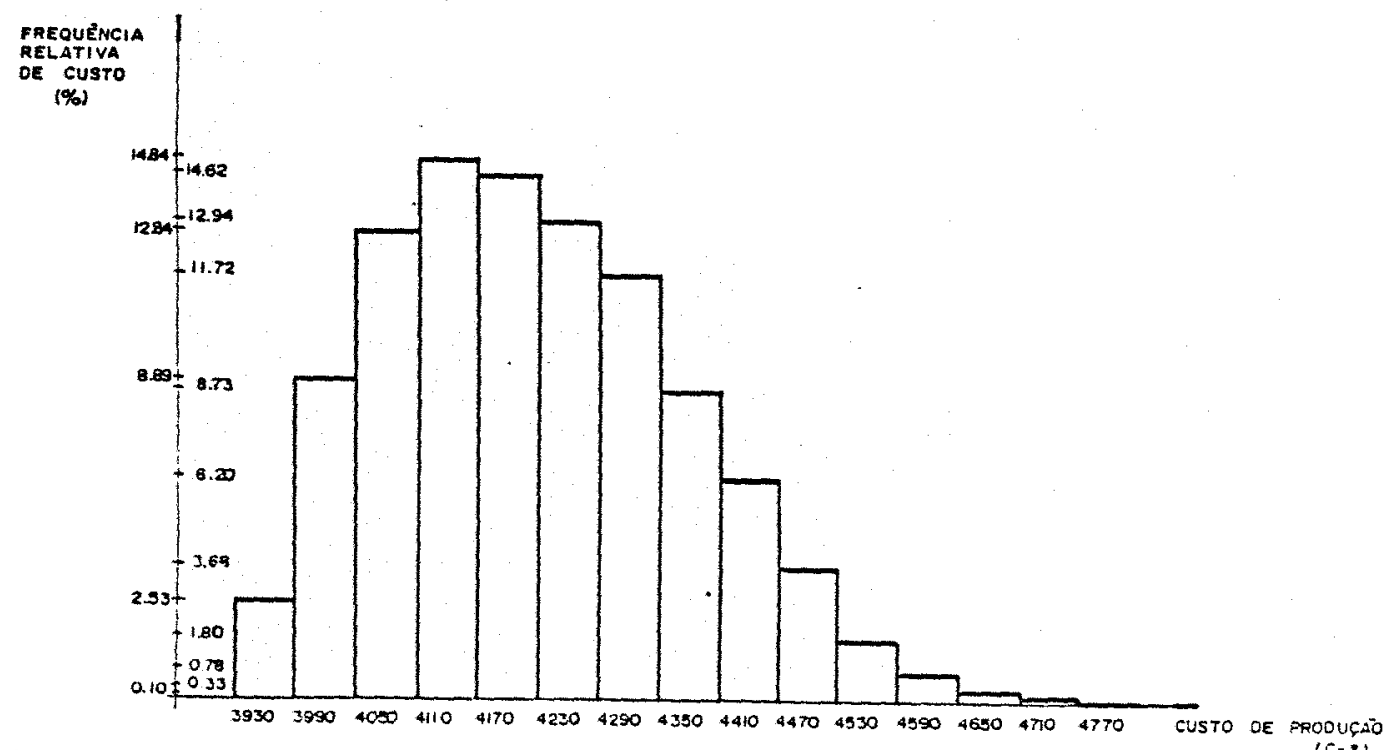

Histograma da distribuição de freqüencias do custo para a cultura $Q$. 